UNIVERSIDADE DE SÃO PAULO

FACULDADE DE FILOSOFIA, LETRAS E CIÊNCIAS HUMANAS

DEPARTAMENTO DE LETRAS CLÁSSICAS E VERNÁCULAS

PROGRAMA DE PÓS-GRADUAÇÃO EM LETRAS CLÁSSICAS

CLARA LACERDA CREPALDI

Helena de Eurípides: estudo e tradução

Versão Corrigida

São Paulo

2013 


\section{Helena de Eurípides: estudo e tradução}

\section{Versão Corrigida}

Dissertação apresentada à Faculdade de Filosofia, Letras e Ciências Humanas da Universidade de São Paulo para obtenção do título de Mestre em Letras

Orientadora: Profa. Dra. Adriane da Silva Duarte 


\section{AGRADECIMENTOS}

À Profa. Dra. Adriane da Silva Duarte pela orientação acurada.

Aos membros do grupo de pesquisa Estudos sobre o Teatro Antigo, pelas discussões muito proveitosas ao meu desenvolvimento como pesquisadora.

Aos que me ajudaram, não sem esforço, a reunir a bibliografia relevante: Marla Silva, Profa. Giuliana Ragusa, Luciano Brito, Prof. Christian Werner, Wilson Alves Ribeiro Júnior, Vitor Schvartz.

A Odorico Leal, primeiro leitor e revisor.

Aos membros da banca de qualificação, Profs. Drs. Jaa Torrano e Christian Werner, pelas observações importantes ao desenvolvimento do trabalho.

À família - aí incluído o clã Hortal - pelo apoio.

Finalmente, à Fapesp pelo financiamento. 


\title{
RESUMO
}

Esta dissertação tem como objeto de estudo a tragédia Helena de Eurípides e sua reinterpretação do mito de Helena. Para tanto, está dividida em duas partes, sendo a primeira um estudo e a segunda uma tradução completa da tragédia em versos. O estudo tem dois capítulos: o primeiro aborda o problema do gênero dramático da peça e alguns aspectos de sua encenação; e o segundo discute imagens tradicionais do mito de Homero a Eurípides, enfatizando a síntese da composição euripideana.

\begin{abstract}
This thesis focuses on the tragedy Helen by Euripides and its reinterpretation of the Helen myth. It is divided in two parts. The first one contains a study and the second offers a complete verse translation of the tragedy. The study presents two chapters. The first deals with the problem of Helen's dramatic genre and some aspects of its staging. The second discusses traditional images of the myth from Homer to Euripides, emphasizing the synthesis of the Euripidean composition.
\end{abstract}


1 INTRODUÇÃO

\section{PARTE I - ESTUDO}

\section{HELENA EM CENA}

2.1 À Procura do Modo Trágico

2.2 O Espaço Cênico da Helena

\section{6}

6

9

3 IMAGENS DE HELENA

$\begin{array}{lll}3.1 & \text { O Paradoxo da Cadela Envergonhada } & 16\end{array}$

3.1 A Farmácia de Helena $\quad 28$

$\begin{array}{lll}3.2 & \text { Fantasmagoria } & 34\end{array}$

4 À GUISA DE CONCLUSÃO

PARTE II - TRADUÇÃo

$5 \quad$ PREFÁCIO À TRADUÇÃO 44

6 TRADUÇÃO 46

REFERÊNCIAS 


\section{INTRODUÇÃO}

O presente trabalho tem como tema o mito de Helena e sua recepção, cujo ponto culminante, nessa dissertação, é a tragédia Helena de Eurípides, encenada pela primeira vez em 412 a.C. ${ }^{1}$. Está divido em duas partes: um estudo introdutório de dois capítulos e uma tradução.

O primeiro capítulo, "Helena em Cena", começa com uma ponderação sobre a questão do gênero dramático da Helena, tendo em vista sua recepção. Nessa parte, discutimos definições antigas e modernas do gênero trágico, defendendo como e em que sentidos a Helena pode ser entendida como trágica. Em seguida, tentamos analisar o espaço cênico da Helena a partir das categorias semióticas propostas por Michael Issacharoff $^{2}$. Nesse exercício, discutimos a questão da dimensão visual do espetáculo trágico, atentando a problemas teóricos específicos como o problema do formato do theatron ateniense e o possível uso de uma cenografia na produção da Helena.

O segundo capítulo, subdivido em três partes, chama-se "Imagens de Helena" e versa sobre três diferentes representações do mito de Helena. A primeira seção é sobre o sentido dos epítetos caninos de Helena na Ilíada e suas implicações, a segunda é sobre

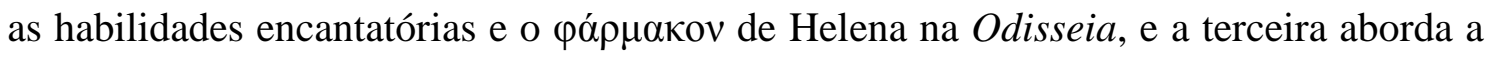
vertente fantasmagórica do mito de Helena, tanto na história do $\varepsilon$ ‘̌ $\delta \omega \lambda o v$ de Estesícoro e Eurípides, quanto na ênfase ao valor simbólico e erótico da imagem de Helena nas versões mais difundidas do mito. O objetivo desse percurso não é buscar origens, mas identificar traços mais ou menos permanentes do mito, que encontramos reunidos na Helena. Sua intenção é explorar o modo como a Helena condensa imagens díspares do mito, intensificando uma ambiguidade da personagem também já reconhecidamente presente em boa parte da tradição, em especial, em Homero.

Por fim, apresentamos a tradução completa da Helena com esclarecimentos introdutórios e notas explicativas sobre o texto e a tradução.

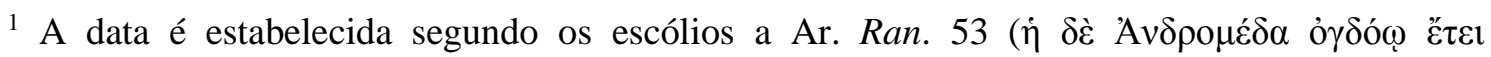
$\pi \rho 0 \varepsilon 1 \sigma \tilde{\eta} \lambda \theta \varepsilon v$, Andrômeda produzida oito anos antes de As Rãs), Thesm. 1012 ( $\sigma v v \delta \varepsilon \delta i ́ \delta \alpha \kappa \tau \alpha$ l

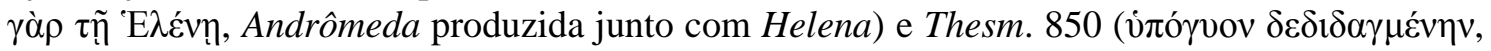
Helena produzida 'recentemente'). A Andrômeda e a Helena, que faziam parte da mesma trilogia, foram parodiadas em As Tesmoforiantes de Aristófanes em 411 a.C.

${ }^{2}$ 1981, p. 211-224. 


\section{HELENA EM CENA}

\section{1 À PROCURA DO MODO TRÁGICO}

Incompatíveis com os modelos de tragédia privilegiados pela crítica moderna, a alguns dramas de Eurípides frequentemente ainda é negada a definição genérica de tragédia. Nesse grupo, além da Helena, também se encontram a Ifigênia em Táuris, Íon, Electra, Alceste e, ocasionalmente, Orestes. Para cada uma dessas peças e de acordo com suas especificidades, o problema do gênero se desdobra de uma certa maneira. Como consequência geral, o estudioso que eventualmente se ocupe de algum desses dramas se depara com a tarefa, um tanto tediosa, de defender, em primeiro lugar, que seu objeto de estudo mereça alguma atenção ${ }^{3}$.

No centro do problema, está uma compreensão romântica do "trágico" como uma categoria universal que caracterizaria a condição humana, sendo a tragédia grega o meio primordial em que essa visão trágica do mundo se manifestaria. Um entendimento assim peca não só por universalizar um fenômeno histórica e socialmente localizado, mas também por postular uma única função para a tragédia, a saber, comunicar essa tal visão trágica ${ }^{4}$.

Por outro lado, não é incomum, em diversas áreas, que um termo científico seja derivado de uma apropriação indevida ou de uma má compreensão inicial de algum fenômeno. Por exemplo, na linguística indoeuropeia, ainda são chamadas de consoantes laringais as consoantes previstas na série usada para reconstrução da protolíngua, porque em algum momento da teorização foi postulado que essas consoantes seriam articuladas na região da laringe, e o nome persistiu, apesar de a teoria depois ter abandonado essa suposição da articulação laringal. Desse modo, os classicistas também não deveriam se ressentir se por acaso a teoria literária usar a tag tragédia para falar de

\footnotetext{
${ }^{3}$ Para a discussão do conceito de trágico, vide Judet de la Combe (2000, p. 97-107) e Coelho (2001, p. 5-19).

${ }^{4}$ É o que Wright (2005, p. 6-43), por exemplo, declara fazer quando defende a tragicidade da Helena e da Ifigênia em Táuris: "Tragedies are (as Aristotle says) serious dramas: and the relabelling as 'un-tragic' of plays which one does not like is simply and excuse to dismiss them without giving them substancial, profound consideration. But the escape-tragedies are worth prolonged, serious attention. This, and perhaps this alone, is the reason why it is worth making a fuss about the genre" (p. 43).
} 
uma "alta forma dramática que incorpora o caos", ou de "um reconhecimento da

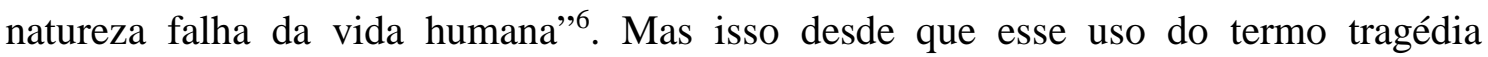
também venha acompanhado de um bom entendimento da diferença entre a origem grega do termo e sua aplicação moderna.

Um exame abrangente da questão no que concerne ao teatro de Eurípides foi apresentado por Mastronarde em um texto que apareceu primeiro como artigo, em $2000^{7}$, e que depois foi incorporado como capítulo de seu livro The Art of Euripides (2010). Mastronarde chama atenção para a variedade e mutabilidade do gênero trágico no séc. V, a despeito da idealização de um conceito transcultural de trágico, fortemente influenciado pelo Romantismo alemão do séc. XIX. O autor também é bastante eficiente na rejeição do uso de rótulos genéricos estranhos ao contexto da Atenas clássica, como melodrama e romance, para a caracterização dessas tragédias supostamente nãotrágicas, quando, no contexto da Atenas clássica, apenas três gêneros dramáticos eram conhecidos: tragédia, comédia e drama satírico. Nesse contexto, a tragédia se definiria em relação aos gêneros concorrentes ${ }^{8}$ sobretudo por aspectos formais: ocasião de performance, uso de máscaras e figurinos, linguagem e metro, motivos e personagens mitológicos, presença do coro, alternância entre episódios e canções corais.

No caso da Helena, em particular, alguns críticos que ainda lhe atribuem defeitos de estilo, às vezes, apreciam-na por sua complexidade intelectual e filosófica ou por sua dimensão religiosa relacionada ao culto de Perséfone/Kóre ${ }^{9}$. Mais recentemente, Coelho (2001, p. 5-19), Wright (2005, p. 6-43) e Allan (2008, p. 66-72), na esteira de Mastronarde, defenderam a tragicidade da Helena também criticando a construção do conceito. Esse autores argumentam principalmente contra a influência romântica na teoria da tragédia e o anacronismo de usar definições teóricas de contextos posteriores para analisar textos clássicos, salientando também o problema de teorizar o gênero baseando-se apenas em algumas tragédias selecionadas ${ }^{10}$.

\footnotetext{
${ }^{5}$ Bentley, 1964, p. 293.

${ }^{6}$ Eagleton, 2005, p. 251.

${ }^{7}$ Mastronarde, 1999-2000, p. 23-39.

${ }^{8}$ Quando falo em gêneros concorrentes, tenho em mente a teoria da synkrisis de Taplin (1986).

${ }^{9}$ Dentre eles, Foley (1992), Hartigan (1981), Robinson (1979), Wolff (1973) e Segal (1971).

${ }^{10}$ Burian (2007, p. 30-35), por seu lado, apesar de afirmar que a Helena é uma tragédia, pelo menos pelo sentido de que ela foi apresentada numa competição trágica (p.30), ainda deixa transparecer em sua compreensão da peça uma concepção bem romântica do trágico: "the world of the play is a tragic one, immersed in the brutalities and stupidities of meaningless strife, unnecessary suffering and undeserved death" (p. 35).
} 
Com efeito, para cada gênero não trágico que se insista em atribuir à Helena, a crítica mais recente já tem uma contestação bem fundamentada. Assim, a Helena não pode ser identificada como romance, se o gênero ainda não existia no séc. V, mesmo que alguns traços presentes na Helena, na Ifigênia em Táuris e também na Odisseia, mais tarde se tornem elementos-padrões do romance antigo. Analogamente, parece inadequado avaliar os disputados elementos cômicos da Helena tomando como base os padrões de cômico da Comédia Nova ou posteriores. Mais descabido ainda é o uso do termo melodrama, uma expressão cunhada apenas no séc. XVIII para designar um drama musical de tom popular recheado de peripécias e imprevistos.

Curioso é observar o modo como esses termos foram aplicados à Helena. Para Grube (1941, p. 352), a Helena é "francamente engraçada"11 e, por isso, cômica. E, se por um lado, é muito elogiosamente que Segal classifica a Helena como romance (1971, p. 556-8); por outro, quando Lee diz que apesar de ser um vilão melodramático, Teoclímeno pode alcançar certa simpatia do público (1986, p. 313), é porque ele entende melodrama como uma espécie de drama maniqueísta, de tipos simples e bem definidos: o herói excelente, o vilão indefensável, etc.

Essa ideia de melodrama como o primo pobre da tragédia, como um drama infantil e menor, é o que parece subjazer à classificação de alguns dramas euripidianos como melodramas em contraposição às elevadas tragédias de Sófocles e Ésquilo. Popularizado em sua forma mais elementar no séc. XIX, o melodrama também foi marcado pelo desprezo da crítica por muito tempo: talvez resida aí a sua maior semelhança com o drama euripidiano.

Insistimos que não, as peças de Eurípides não são melodramas, nem romances, nem qualquer outra coisa que não tragédias. E não poderia ser diferente, considerando que: essas peças foram inscritas e aceitas como tragédias nos festivais; elas compartilham de uma mesma estrutura formal, com partes faladas em metro iâmbicos e partes cantadas em ritmos diversos; suas personagens principais vêm sempre do mito;

\footnotetext{
${ }^{11}$ Em sua análise da peça, Grube ainda chega a imaginar se o público não se irritaria em assistir a uma tragédia transformada em comédia diante de seus olhos (1941, p. 333). Para Kitto, a Helena é comédia do começo ao fim, apesar da matança dos egípcios narrada pelo mensageiro e da "nota puramente trágica" da primeira ode coral (1950, p. 313). Grégoire também é de opinião que a ironia da Helena era mais cômica do que trágica (1950, p. 38). A interpretação de PippinBurnett da Helena como "comédia de ideias" é mais sofisticada, mas também mais anacrônica: a autora chega a dizer que Eurípides tomara emprestado o motivo do casamento da Comédia Antiga (?) (PIPPIN, 1960, p. 155).
} 
seus atores usam máscaras e vestimentas específicas; e todas elas têm um coro que coletivamente canta, dança e comenta a ação dramática.

Dito isso, há um certo aspecto do melodrama que seria interessante avaliar em Eurípides. Em livro sobre a história do melodrama francês moderno, Thomasseau afirma o seguinte:

A arte do melodrama repousa [...] quase que inteiramente, nas situações, numa mise en scène perfeita e no talento dos atores, sendo que destes últimos elementos o que resta atualmente são apenas o texto das rubricas e algumas piedosas lembranças em velhos artigos. (2005, p. 10)

De modo análogo, quando Lesky fala sobre a crescente importância da direção e da representação no teatro pós-clássico, ele diz:

Já Eurípides nos permite notar de maneira nítida a aspiração a quadros cênicos de efeito. Basta lembrar as cenas de abertura a exibir os suplicantes estendidos junto a um altar, ou a cena final de Orestes, em três níveis, com Menelau diante do palácio, o grupo em torno de Orestes sobre o telhado, e Apolo com Helena num theologeion, que é preciso imaginar em plano mais elevado. (1971, p. 233)

Sobre temas muito diferentes, esses dois autores citados enfatizam a importância da mise-en-scène prevista além do mero texto dramático de que dispomos. Tendo isso em mente, e sem nenhuma intenção de atribuir o drama de Eurípides ao gênero melodramático ${ }^{12}$, vale a pena investigar qual seria, no teatro de Eurípides, a dimensão

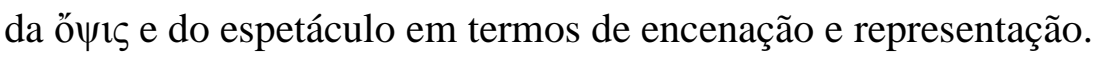

\subsection{O ESPAÇO CÊNICO DA HELENA}

\footnotetext{
${ }^{12}$ No prefácio à edição original do seu The Melodramatic Imagination [1976], Peter Brooks cita autores que reavaliam o gênero melodramático e diz: "Some of these authors suggest - Bentley most explicitly and persuasively - that melodrama at heart represents the theatrical impulse itself: the impulse toward dramatization, heightening, expression, acting out. Then to conceive melodrama as an eternal type of the theatre, stretching from Euripides to Edward Albee, is a logical step, and one that Rosenberg, Heilman, and Smith explicitly make and document. Yet here I think the term may become so extended in its meaning that it loses much of its usefulness, at least for our purposes. When Euripides, Shakespeare, and Molière all become melodramatists at least some of the time, and when tragedy becomes only a special subset of melodrama, we lose a sense of the cultural specifity of the genre." (BROOKS, 1995, p. xv)
} 
O problema tangencia a questão do letramento. Em Aristóteles, a desconsideração da ő $\psi 1 \varsigma$, que, na Poética, é a parte menos artística e que menos tem relação com a poética trágica, está relacionada a uma primazia que Aristóteles dá à palavra poética frente à dimensão espetacular do drama. Em três trechos diferentes em que menciona a ő $\psi 1 \varsigma$, Aristóteles diz que a força da tragédia se mantém mesmo sem àyóv e sem atores (VI, 1450b16-20), que é preferível que o temor e a piedade sejam suscitados pelo próprio arranjo das ações, ao invés de surgirem do espetáculo (XIV, 1453b1-3), e que a tragédia se dirige a espectadores mais vulgares que os da épica, porque a esses se deve mimetizar tudo (XXVI, 1461b26-29). Um raciocínio similar aparece em uma carta em que Cícero censura a espetacularização excessiva da tragédia contemporânea a ele e diz que o espetáculo muito elaborado tira o prazer da performance (Fam. 7.1.2). Nos dois casos, à antipatia ao espetáculo subjaz uma ideia de oposição entre o elemento literário (poético) e o elemento espetacular. Para Taplin, essa

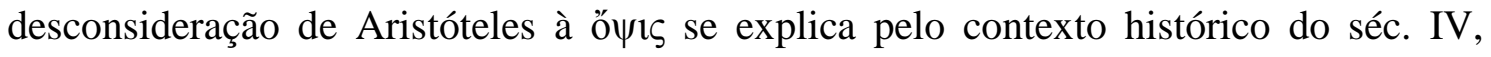
quando se tornou possível tratar o texto de uma tragédia grega como a própria tragédia e não como o libreto de uma performance ${ }^{13}$.

$\mathrm{O}$ trabalho do próprio Taplin foi fundamental, na segunda metade do séc. XX, para uma retomada de interpretações que fazem jus à dimensão cênica da tragédia grega. Desprezando a controversa divisão da tragédia proposta por Aristóteles na Poética XII, a tese básica de Taplin postula que a estrutura da tragédia "é baseada na interação entre (i) os dois modos principais de elocução (fala dos atores/canto coral) e (ii) a articulação da ação por meio de entradas e saídas" (2003, p. 20). Desse modo, o que separa os atos de uma tragédia são as canções, e essas canções são precedidas por saídas e seguidas de entradas. Em conformidade com essa tese, Halleran (1985) enuncia as três regras básicas para entradas e saídas na tragédia: (1) Anúncios de entradas ocorrem apenas quando há mais de uma pessoa em cena. Por exemplo, no v. 68, Helena não anuncia a chegada de Teucro, porque, no momento, ela está sozinha no palco. (2)

\footnotetext{
${ }^{13}$ Nas palavras de Taplin: "On the particular topic of visual meaning Aristotle's failure seems to lie in his times. During the fourth century it had become possible to regard the text of a Greek tragedy as the tragedy itself and not as a libretto of a performance. This attitude is not to be found in Plato, and may to some extent be a reaction to Plato's emphasis on performance. Once tragedy is treated as a text then it is all too easy to lose sight of its visual meaning." (1989, p. 25) Reconheço aqui outro paralelo com o melodrama francês moderno: "Pixerécourt, com muita lucidez, reconhecia escrever para aqueles 'que não sabem ler'”. (THOMASSEAU, 2005, p. 28)
} 
Entradas imediatamente após canções estróficas não são anunciadas, como, por exemplo, na primeira entrada de Teoclímeno (v. 1165), logo após o primeiro estásimo. (3) Entradas não imediatamente após canções estróficas são anunciadas, como no caso da entrada de Teônoe introduzida por Helena nos vv. 858-9.

Ainda segundo Halleran, quando essas regras são quebradas, elas o são propositadamente. Quebrando as regras, o dramaturgo manipula as expectativas da plateia para atingir certos efeitos. Há os casos de entradas surpresas, operadas para mudar o curso do drama. É o que acontece com o servo que faz as vezes de mensageiro e aparece para contar do desaparecimento do $\varepsilon i \delta \omega \lambda$ ov logo no momento em que Menelau iria abandonar Helena no Egito, sem reconhecê-la como sua esposa (vv. 597624). Em um momento crucial da trama, essa entrada surpresa é necessária para que o enredo se desenrole no modo original em que se desenrolará ${ }^{14}$.

Em contexto moderno, estudiosos do teatro também se debruçam sobre o problema do espaço cênico. Para um dos mais importantes deles, o teórico Michael Issacharoff, "a tensão dramática é frequentemente dependente da antinomia entre espaço visível representado e espaço invisível descrito". (1981, p. 211). Na teoria de Issacharoff, o espaço cênico é dividido em espaço do teatro (theater space), espaço do palco (stage space) e espaço do drama (dramatic space). O primeiro é determinado pelo design arquitetônico do teatro, que impõe certas limitações. O segundo é o design do palco e do cenário, incluindo cenografia, figurino e o próprio corpo do ator. O terceiro é o espaço criado pelo discurso dramático, seja como espaço mimético, isto é, visível em cena, seja como espaço diegético, quando o discurso dramático se refere a espaços fora do palco, mediados pela linguagem.

Caso se adote essa teoria para análise do espaço cênico de uma tragédia grega antiga, a primeira dificuldade seria entender o espaço do teatro, uma vez que a arquitetura do theatron ateniense é um problema dos mais discutidos pelos especialistas. De um lado, há os que defendem um formato original circular para a orchestra, de outro, há os que preferem supor um formato retangular/trapezoidal, sendo que as teorias do formato circular costumam envolver implicações filosóficas, políticas e sociais à

${ }^{14}$ Halleran, 1985, p, 33. 
tragédia, relacionadas ao significado do círculo (como representação do cosmos, por exemplo) ou ao modo de recepção do espetáculo pelo público ${ }^{15}$.

Passando ao espaço do palco, teríamos de tratar de outros aspectos da tragédia grega também muito obscuros, como a cenografia, os figurinos e o estilo de interpretação. De volta aos quadros cênicos de efeito mencionados por Lesky, recordamos que a Helena começa com uma dessas típicas cenas de abertura euripidianas, com suplicantes estendidos sobre altares. A estrutura do prólogo dessa peça é uma característica marcante do estilo de Eurípides, parodiada por Aristófanes n'As Tesmoforiantes (1177-1250) e presente em outras sete tragédias completas (Heráclidas, Andrômaca, Héracles, Ifigênia em Táuris, Fenícias, Orestes e Bacantes). Em monólogo, a personagem principal, Helena, explica em que pé está a situação - uma explicação nem um pouco dispensável no caso da intricada trama da Helena - e também expõe seus sentimentos e motivações, que devem orientar a resposta do público aos próximos desdobramentos. O primeiro verso e a primeira palavra da Helena já localizam a trama em um determinado espaço, o Egito $^{16}$ :

Do Nilo são estas correntes de belas virgens que, em lugar da chuva de Zeus, molham a terra, o torrão egípcio, quando derretida a branca neve. (1-3)

Neí

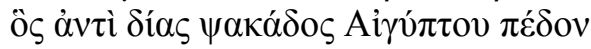

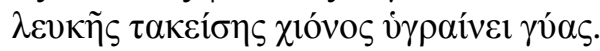

Ainda no monólogo de abertura, depois de falar da descendência de Proteu e de explicar sua própria origem e história, Helena diz que agora que o rei que a protegia morreu, ela está sendo perseguida por seu filho Teoclímeno que quer se casar com ela. E daí nos versos 63-5, Helena diz:

E, em honra ao marido de antanho, estou ajoelhada neste mausoléu de Proteu, como suplicante, a fim de que isso preserve o meu leito para Menelau.

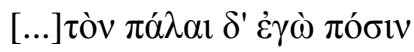

\footnotetext{
${ }^{15}$ Sobre evidências arqueológicas para o formato circular, vide Moretti, 1999-2000, p. 377-398. Para um resumo da questão com bibliografia, vide Rehm, 2002, 37-41.

${ }^{16}$ Para Arnott (1990, p. 2-3), a cena de abertura da Helena fisga a atenção dos seus espectadores pela situação incomum da personagem e por esses versos iniciais, que enfatizam um cenário também incomum.
} 


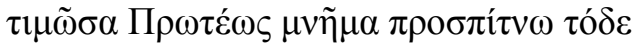

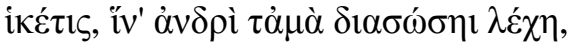

Helena menciona o túmulo usando o pronome demonstrativo $\tau$ ó $\varepsilon \varepsilon$, o que faz supor uma presença de um objeto cênico representando o túmulo em questão. Essa interpretação é reforçada por outras menções ao túmulo no texto: Helena se esconde atrás dele, diz que está tocando-o e também aponta a Menelau o leito em que ficava como suplicante para se proteger de Teoclímeno (vv. 543-4; 556, 797-801).

Depois do monólogo de abertura, ainda no prólogo, ocorre um significativo encontro entre o herói grego Teucro e Helena. Antes de vê-la, porém, Teucro diz:

Quem será o senhor deste palácio fortificado?

Pois do próprio Pluto é digna uma morada assim,

tão régias as suas muralhas e tão bem acimalhadas as suas câmaras.

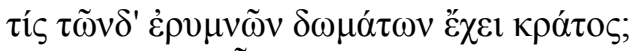

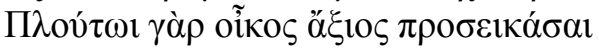

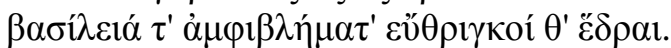

(vv. 68-70)

Nesse ponto, Allan (2010, p. 157) sentencia: "Isso é uma pintura de cena verbal, que não precisa corresponder à aparência real da skené." A questão é complicada, mas há mais ou menos consenso de, que pelo menos a partir da data de encenação da Oresteia (458), havia no palco uma estrutura de madeira, com uma porta dupla no meio

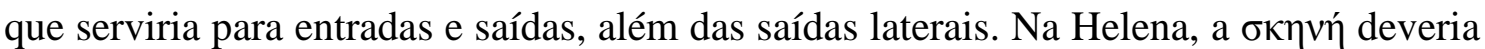
representar o palácio de Proteu/Teoclímeno, mas é difícil dizer se haveria uma

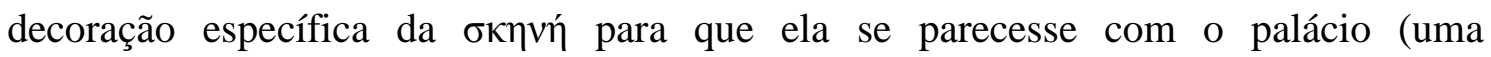

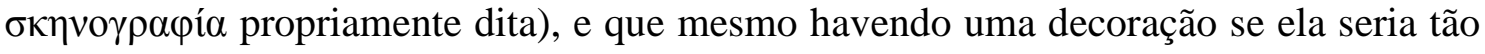
detalhada como a descrição de Teucro.

Para Barlow (1986, p. 21-22), por exemplo, é justamente por causa da pobreza da cenografia que o coro euripideano frequentemente descreve o espaço em que se encontra, como na segunda estrofe do párodo da Helena (vv. 179-84):

Perto d'água azul-marinha

e da relva espiralada, estava eu secando os fenícios peplos sobre brotos de junco, ao sol de dourados raios: de lá ouvi lamentável ruído (...) 
No entanto, não há fontes contemporâneas que digam com precisão que parte da tragédia caberia ao espetáculo e que parte viria apenas como descrição verbal, pois a própria técnica do espetáculo é provavelmente a parte mais desconhecida da tragédia clássica. Aos comentaristas modernos não resta mais do que o bom senso para tentar adivinhar o que seria ou não representado em cada tragédia. Em todo o caso, o uso dos pronomes demonstrativos para se referir a prováveis objetos cênicos não deve ser tratado como argumento suficiente para inferir a presença ou não desses objetos em cena. No caso específico da Helena, também não é impossível imaginar que não houvesse nem cenografia detalhada e nem mesmo uma representação do túmulo.

No tocante ao figurino, por sua vez, o texto da Helena nos fornece alguma informação mais consistente. Pela caracterização cômica de Aristófanes que não se cansa de zombar dos reis-mendigos de Eurípides, notadamente de Télefo, o rei da Mísia coxo e disfarçado de mendigo do drama de 438 a.C. ${ }^{17}$, confirmamos a importância desse recurso no teatro euripidiano. Nesse aspecto, o primeiro destaque da Helena são os andrajos de Menelau, que não só envergonham o próprio herói (vv. 415-417) e assustam Helena por seu aspecto "selvagem" (vv. 544-545; 554), como também causam repulsa até mesmo a Teoclímeno (v. 1204). Helena, por seu lado, usa vestes brancas (v. 1088), talvez sinalizando a castidade mantida durante a ausência de seu legítimo esposo. Nesse contexto, a troca de roupas dos dois protagonistas marca a reviravolta do enredo, assinalando o momento em que o plano de fuga de Helena e Menelau começa a ser posto em ação. Para bem simular o seu luto pelo marido falsamente morto, Helena troca seu peplos brancos por pretos e corta mechas de seu cabelo (vv. 1086-1088). Tal fingimento convence Teoclímeno de que Menelau está morto e de que Helena, enlutada, deseja apenas fazer um funeral ao falecido para então se casar com o tirano. Ludibriado, Teoclímeno oferece vestes dignas a quem ele acredita ser apenas um náufrago grego qualquer (vv. 1282-1283). É aí então que Menelau abandona seus andrajos e passa a vestir roupas apropriadas, que o ajudam a restabelecer seu status de herói. Mais tarde, veremos Menelau na proa do navio, depois de lavado e paramentado pela própria Helena (vv. 1382-1384), a conclamar os seus marinheiros a lutarem contra os bárbaros (vv. 1593-1595) e depois também derrotando os inimigos e salvando heroicamente os seus aliados em perigo (v. 1606-1610).

\footnotetext{
${ }^{17}$ E. g. Pax 146-8; Ach. 410-413, 424, 426-30.
} 
De resto, é no espaço do drama, entre as categorias de Issacharoff, que podemos perceber com mais clareza um sistema semiótico que se estabelece entre os espaços visíveis e não visíveis da Helena. No espaço mimético, impera o Egito, um lugar de morte e esquecimento, mas que é também o espaço da inocência e da castidade de Helena. Por outro lado, no espaço do discurso, também aparecem Troia e Esparta. Em contraposição ao Egito que é o lugar da Helena "verdadeira", Troia é o lugar do

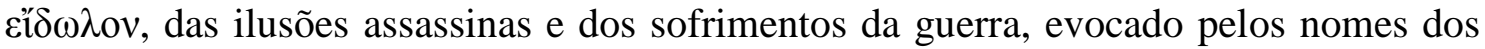
rio Simoente (v. 250) e Escamandro (v. 52-53, 369 e 609-610) e pelas referências ao monte Ida (v. 24, 29, 197, 1324 e 1508). E em contraposição ao Egito onde Helena, sozinha, é perseguida por Teoclímeno, Esparta é o lar do casal Helena e Menelau, representada pelo Eurotas (v. 162, 209-210, 349-350, 493 e 1492) e pelo templo da virgem Atena (v. 228, 245, 1466-1467) ${ }^{18}$. Esparta aqui representa, de fato, a própria grecidade de Helena e Menelau, contrária à barbárie egípcia que não respeita nem ao menos as sagradas obrigações da hospitalidade.

Outro espaço diegético que convém observar é a caverna que guarda o gǐ $\delta \omega \lambda o v$ e é cenário de sua transformação. No discurso do primeiro mensageiro (vv. 601-621), ela

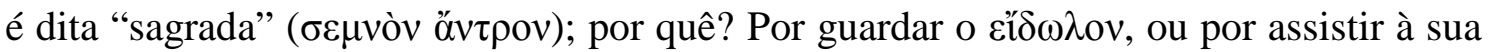
despedida, iluminada por seu discurso revelador? Algo de prodigioso, certamente, acontece na caverna, no momento em que o $\varepsilon$ í $\delta \omega$ ov denuncia como a história grega da guerra de Troia foi construída sobre uma espécie de mentira fundamental.

No meio termo entre Egito e Esparta, a nau usada para a fuga, que aparece no discurso do segundo mensageiro, parece ser o espaço em que a Helena egípcia completa sua assimilação à Helena troiana - assunto abordado no próximo capítulo.

Para finalizar, assinalamos que, ainda que a encenação do drama euripideano seja inacessível para nós, o texto da Helena nos permite vislumbrar uma rica construção de cenários (representados ou não) e um jogo de figurinos essenciais à sua trama. Mais do que nos lembrar da verdade fundamental de que o texto da tragédia não é a tragédia inteira, a Helena aparece como uma viva demonstração da desenvoltura com que Eurípides explora os elementos cênicos e as regras do palco para criar cenas de forte efeito.

${ }^{18}$ Amiech, 2011, p. 149. 


\section{IMAGENS DE HELENA}

\subsection{O PARADOXO DA CADELA ENVERGONHADA ${ }^{19}$}

Sob variadas formas, o mito diz que a expedição grega a Troia tinha por objetivo recuperar Helena, a espartana, que havia sido roubada de seu marido e de seu palácio pelo troiano Páris. Roubada, como coisa que se rouba, porque antes de tudo Helena é artigo de alto valor simbólico, objeto de disputa, prenda de guerra ( $\gamma \varepsilon \dot{\varepsilon} \rho \varsigma \varsigma$ ) e dádiva

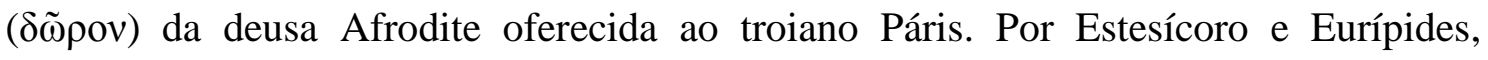
sabemos que, na Grécia arcaica e clássica, já havia uma vertente do mito que radicalizara esse valor simbólico da Helena de Troia a ponto de transformá-la em mero espectro, um $\varepsilon i \delta \omega \lambda$ ov enganador.

Em Homero, porém, a história não fica por aí. Na Ilíada e na Odisseia, Helena é um personagem complexo, que, além de possuir esse valor simbólico, também aparece como um sujeito com vida interior própria e poderes incomuns não só a outras mulheres em condições semelhantes, mas também a todos os outros personagens humanos das epopeias homéricas. Especialmente na situação de guerra da Ilíada, Helena demonstra ter consciência de si e de suas responsabilidades e é até mesmo capaz de vislumbrar o alcance de sua história nas futuras canções dos aedos ${ }^{20}$. Se a Helena de Homero não é só

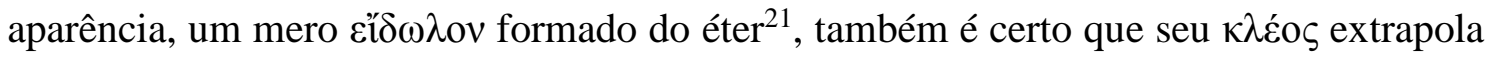
a sua própria medida num prenúncio do que será a Helena fantasmagórica de Estesícoro ou Eurípides.

Em Homero, as atitudes em relação a Helena são um tanto variáveis. Bem tratada pelos troianos e compreendida até mesmo por Penélope ${ }^{22}$, Helena tem em si

${ }^{19}$ Esta primeira seção é uma versão revisada do artigo "Entre Cães e Cadelas: a Helena da Ilíada", publicado na revista Nuntius Antiquus (CREPALDI, 2012, p. 51-65).

${ }^{20} \mathrm{Il}$. VI.357-8.

${ }^{21}$ E. Hel. 584.

${ }^{22} \mathrm{Na}$ cena de reconhecimento de Penélope e Ulisses, a esposa do herói justifica sua resistência em reconhecer o marido dizendo que nem mesmo Helena teria dormido com um estrangeiro, se soubesse que os gregos empregariam a força para resgatá-la, porque fora um deus que a fizera

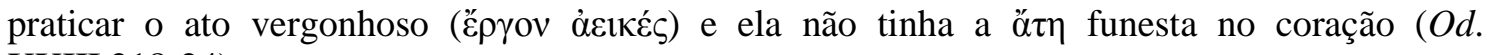
XXIII.218-24). 


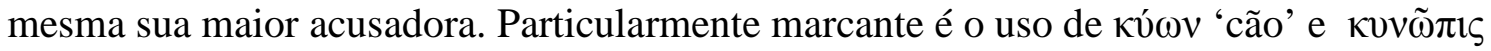
'cara de cadela', insultos comuns em outras partes da Ilíada e da Odisseia, mas somente autodirecionados por Helena ${ }^{23}$. Para entender melhor o significado desse tipo de insulto e, em especial, sua aplicação a Helena, examino, a seguir, a apresentação geral da figura

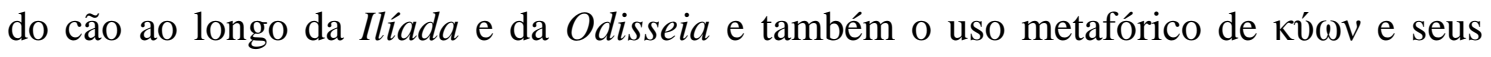
derivados para caracterizar outros personagens, em sentido negativo ou não. Voltarei, por fim, a Helena, seguindo o rastro de suas aparições na Ilíada, para entender os efeitos

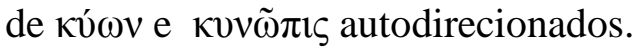

Já no proêmio da Ilíada, somos apresentados a uma função homérica do cão das mais detestáveis: a de carniceiro (Il. I.1-5) ${ }^{24}$. Para um guerreiro que eventualmente morresse no campo de batalha, havia sempre a ameaça de se tornar repasto para os cães

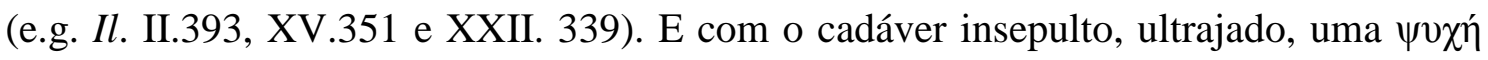
de um herói nem mesmo conseguiria acesso ao Hades, tivesse sido ele bravo ou covarde, nobre ou vil. Essa selvageria é o primeiro e um dos mais evidentes traços do ethos canino em Homero e pode ser relacionada a uma $\alpha$ voí $\delta \varepsilon 1 \alpha^{25}$, frequentemente atribuída aos cães e usada como explicação aos epítetos derivados ${ }^{26}$.

O campo de guerra onde se passa a maior parte da Ilíada não é exatamente o cenário mais propício a cães, e, portanto, a maior parte dos cachorros dessa epopeia aparece em símiles ou metáforas. No caso dos símiles, o comum é que cenas de combate humano sejam comparadas a atividades de caça com cães (e.g. Il. III.23-6 e XI.414-18), pelo que ficamos sabendo que esse cão arcaico é sobretudo um caçador.

Outra função de utilidade do cão é a guarda, que aparece em símile (Il. X.183-6), ou na figura concreta dos cães de guarda de Alcínoo (Od. VII.91-4), Príamo (Il. XXII.66-71) e Eumeu (Od. XIV.21-2). A esses se juntariam, talvez, Cérbero, o cão odioso de Hades (Il. XIII.368) e também os leões e lobos enfeitiçados de Circe, que abanam a cauda como cães interesseiros (Od. X.212-8). No caso dos cães de Príamo, cabe notar que esses mesmos animais que o rei troiano diz ter criado à sua mesa são aqueles que vão profanar o seu cadáver, quando Troia tiver caído. A passagem indica que, mesmo domesticado, esse cão homérico permanece a um passo da selvageria

\footnotetext{
${ }^{23}$ Como observa Graver (1995, p. 41).

${ }^{24}$ Cães carniceiros também são comuns na Odisseia, e.g. Od. III.259; XIV.134; XVIII.87; XXI.363; XXII.476.

${ }^{25}$ CORRÊA, 2010, p. 401.

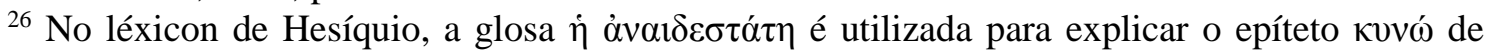
Hécate.
} 
carniceira, ainda longe de ser um dócil animal de estimação (KITCHELL 2002, p.177$8)$.

Na Odisseia, em particular, essa utilidade de guarda do cão é destacada e até posta em contraste com uma criação de cães apenas para o luxo de seus senhores

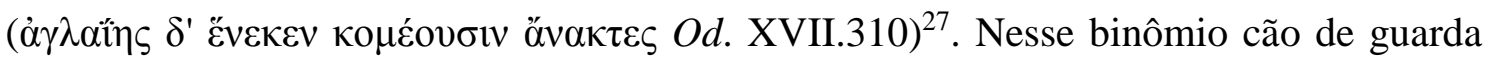
versus cão de exposição, o velho cão de Ulisses, outrora um exímio caçador ( $O d$. XVII.316-7), e também os cães de guarda de Eumeu serviriam para sublinhar a diferença entre a produtividade da casa e do reino de Ulisses e a vã ostentação dos pretendentes (SCODEL, 2005). Mas justamente porque essa diferenciação entre esses dois tipos de cão está inserida no discurso de Ulisses e na economia própria da Odisseia, marcada pela diferença de caráter entre o legítimo soberano de Ítaca e aqueles que querem tomar o seu lugar, talvez ela não mereça muita consideração numa avaliação geral do ethos canino.

Ainda sobre os cães de guarda de Eumeu, vale a pena notar que esses cães não simplesmente atacam quem quer que se aproxime, como no caso da chegada de Odisseu (Od. XIV.21), mas também saúdam amigavelmente os conhecidos, como no caso da aparição de Telêmaco (Od. XVI.4-10), e, mais surpreendentemente, têm a intrigante capacidade de perceber uma presença divina que somente Odisseu entre os homens é capaz de enxergar (Od. XVI.162-3).

Perto do final da Ilíada, no funeral de Pátroclo (Il. XXIII.164-83), Aquiles degola dois dos nove cães criados pelo amigo à sua mesa ${ }^{28}$, para acrescentá-los à pira de seu dono - pira que, aliás, já contava com ovelhas, bois, mel, azeite, quatro cavalos e doze prisioneiros troianos. A própria presença desses tantos cães no acampamento de guerra soa um tanto anômala, mas me parece que a tentativa de racionalizar demais essa presença seja superinterpretar um detalhe de uma narrativa que, de resto, não é realista. Richardson (1993, p. 188-9) nota que esse sacrifício de cães, cavalos e homens é único em Homero e parece sinalizar a magnitude do sofrimento de Aquiles pela perda de Pátroclo. Mas, se o sacrifício dos troianos tem a finalidade óbvia - explícita no discurso

\footnotetext{
${ }^{27}$ Sobre a relevância desse contraste no contexto da cena de Argos, vide Scodel (2005).

28 ' $\tau \rho \alpha \pi \varepsilon \zeta \varepsilon v ́ \varsigma$ ', o adjetivo usado aqui, também aparece na descrição dos cães de Príamo e na caracterização que Odisseu faz do 'cão de banquetes' (expressão de Carlos Alberto Nunes), criado apenas para luxo de seus senhores. No contexto dos cães de Pátroclo e Príamo, a expressão parece indicar apreço especial a esses animais criados quase como convivas de seus donos, mas é bom lembrar que $\tau \rho \alpha \pi \varepsilon \zeta \varepsilon u ́ \varsigma$ também pode ser usado para caracterizar um parasita ou conviva indesejado (' $\pi \alpha \rho \alpha ́ \sigma ı \tau o \varsigma ~ \alpha ̋ \kappa \lambda \eta \tau ం \varsigma ’$ na glosa de Hesíquio).
} 
de Aquiles - de vingar o assassinato de Pátroclo, não fica tão clara assim qual seria a funcionalidade do sacrifício dos cães e dos cavalos. A ideia, manifesta em Luciano ( $D e$ luctu, § 14), de que esses animais poderiam ser aproveitados pelo morto no Hades também não resolve a questão de qual seria exatamente essa utilidade, de companhia, guarda ou caça. Em todo caso, não há motivo nenhum para acreditar que esses cães seriam "carinhosamente assassinados" por Aquiles para ocupar "o lugar de mais alta honra" na pira de Pátroclo, como quer Scott (1948, p. 228) ${ }^{29}$.

De quase todos esses cães mencionados até aqui não é possível perceber nenhuma manifestação clara de afeto aos humanos, nem por parte dos próprios cães, nem por parte de seus donos. Em Homero, a exceção é Argos.

Nas incontáveis glosas à cena de reconhecimento de Ulisses e seu cão, os comentadores já identificaram diversos estratos de interpretação: antes de qualquer coisa, o pathos da condição de Argos e sua morte; sua lealdade; a posição desse episódio na série de reconhecimentos do final da Odisseia; a identificação do estado do cão com o estado da casa e com o estado do dono; o prenúncio de acontecimentos ainda por vir (BECK, 1991; JONG, 2001, p. 421; REECE, 1993, p. 170; ROSE, 1979). Para os fins dessa investigação, o que cumpre observar é precisamente essa relação de afeto, amizade e lealdade entre Ulisses e seu cão. Velho e mal tratado, Argos reconhece Ulisses sem ajuda de nenhum sinal - ele é o único, em Ítaca, a fazê-lo - e usa suas últimas forças para saudar o seu dono antes de morrer. Odisseu, de sua parte, pode apenas esconder uma lágrima furtiva para não revelar sua verdadeira identidade ao porqueiro Eumeu.

A cena de Argos inicia uma importante identificação de Ulisses com o cão, que,

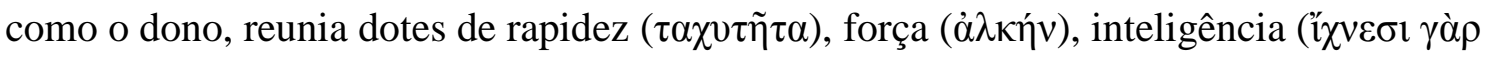
$\pi \varepsilon \rho \eta n ́ \delta \eta)$ e resistência a condições adversas. Essa identificação vai ser desenvolvida mais tarde na descrição do broche que Ulisses usava quando partiu de Ítaca ( $O d$. XIX.225-31) e no símile da cadela que late aos estranhos para defender os seus filhotes (Od. XX.13-6). No primeiro desses trechos, lê-se o seguinte:

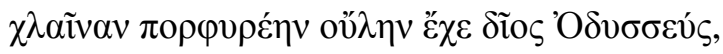

${ }^{29} \mathrm{O}$ comentador narra o trecho da seguinte forma: "Here it is told how under the guidance of Achilles a pile of wood one hundred feet square was erected, sheep in great numbers were slain, cattle were added, then four fine horses were put on the pyre, and finally uppermost and in the place of greatest distinction two dogs, table companions of Achilles, tenderly slain by the hero himself, were offered in honor of Patroclus." [grifos meus] 


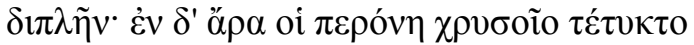

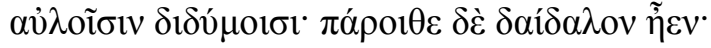

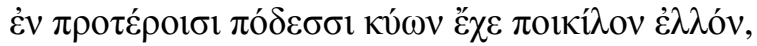

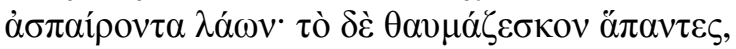

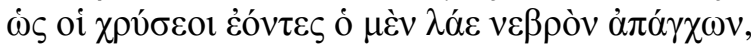

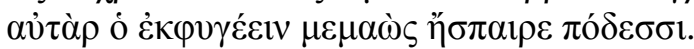

Manto purpúreo, de lã, envergava o divino Odisseu, muito amplo e cômodo, preso por áureo colchete vistoso, de duplo encaixe, com jóia admirável na parte da frente: um cão sustinha nas patas da frente uma corça listrada, que estrebuchava. Ante o grupo nós todos sentíamos pasmo: como, sendo ouro, podia o mastim prear a corça e esganá-la? E como a corça tentava fugir, a espernear tanto e tanto? ${ }^{30}$

(Od. XIX.225-31)

Rose (1979, p. 224 e ss.) analisa a figura desse broche, comparando-o a três símiles que contêm cenas semelhantes na Ilíada ${ }^{31}$, e conclui que a impotência da corça perante a força do cão antecipa a impotência dos pretendentes diante da fúria da vingança de Ulisses. Também apoia essa interpretação um outro símile que aparece mais cedo na Odisseia, quando, em Esparta (Od. IV.335-40), Menelau diz o seguinte sobre os pretendentes:

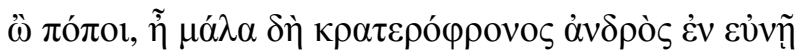

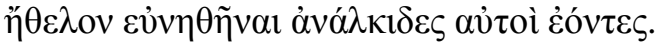

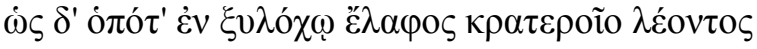

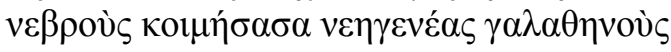

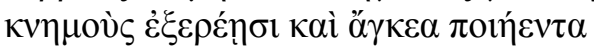

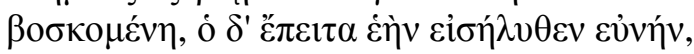

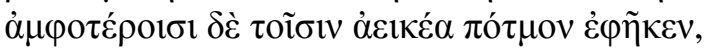

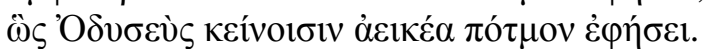

Pois é possível que tais indivíduos, sem força nenhuma, queiram deitar-se no leito de um homem como esse, tão forte! Bem como quando, no espesso do bosque, onde um leão

leito fizera, uma corça aí deixara seus tenros filhinhos, [formidando para sair a pastar pelos cerros e vales ervosos; mas o leão para o pouso retorna, passados momentos, e logo, ali, a ambos eles com morte horrorosa extermina: do mesmo modo Odisseu a eles todos dará morte horrível.

(Od. IV.333-40)

30 Todas as traduções citadas da Odisseia são de Carlos Alberto Nunes (1974).

${ }^{31}$ X.360-62: Odisseu e Diomedes perseguem Dólon, como cães atrás de uma corça ou lebre; XV.579-81: Antíloco se lança sobre o cadáver de Melanipo como um cão sobre um gamo ferido; XXII.189-92: Aquiles persegue Heitor ao redor das muralhas de Troia como um cão no rastro de um gamo. 
O trecho reapresenta a fragilidade e impotência dos pretendentes-corças, diante, dessa vez, de um Ulisses-leão. Esse símile ainda é repetido mais uma vez por Telêmaco, já em Ítaca (Od. XVII.126-31).

O Ulisses-cão reaparece mais tarde em um símile do canto XX (v. 13-16). Sem conseguir dormir, porque planeja males para os pretendentes, Ulisses ouve o riso das criadas traidoras, que costumam se unir aos seus inimigos e, enfurecido, pensa em matálas naquele instante. Nesse momento, o seu coração late no peito,

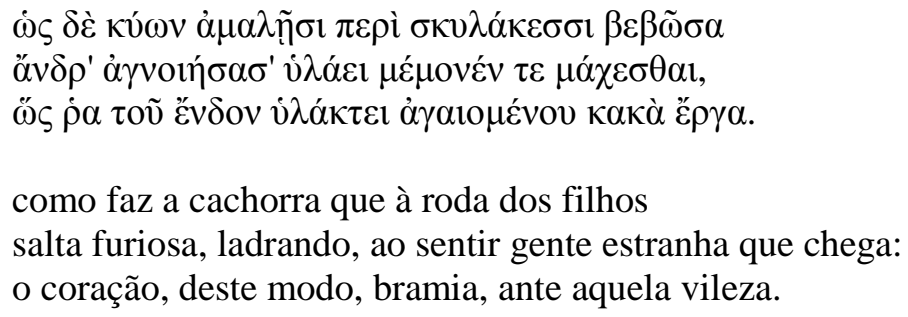

(Od. XX.14-6)

Dessa vez, a característica canina que Ulisses assume é a guarda aguerrida de sua casa e dos seus. Para arrematar, a continuação do trecho relembra um episódio ainda mais cachorro ( Ulisses, episódio que ecoa no símile da cadela, porque no canto IX (v. 289), Polifemo arrebata dois dos companheiros aqueus como se fossem cachorrinhos ( $\varsigma_{\varsigma} \tau \varepsilon \sigma \kappa v ́ \lambda \alpha \kappa \alpha \varsigma$ ).

Nessa sequência que inclui o encontro com Argos, a descrição do broche e o símile da cadela, o personagem central da Odisseia assimila características caninas com valor positivo. Mas não é por isso que chamar alguém de cão deixa de ser insulto na Odisseia. No canto XVII, apenas um pouco antes do encontro com Argos, Eumeu e Ulisses passam pelo pastor Melântio, que sem reconhecer o amo, o injuria, agride e

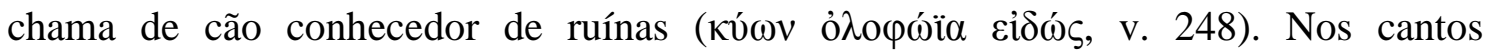
seguintes, a cadela será a irmã de Melântio, a serva Melanto, que, por também abusar do mendigo Odisseu, é chamada de cadela pelo próprio herói (Od. XVIII.338) e de cadela

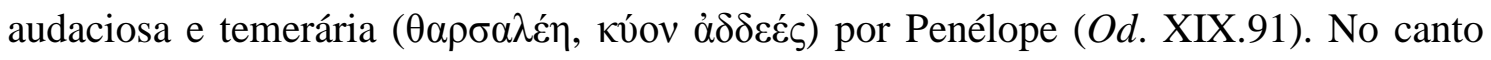
XIX, as servas de um modo geral são chamadas de cadelas mais duas vezes, uma por Penélope (v. 154) e outra por Euricleia (v. 372).

Assim como seus pares femininos, os pretendentes também são chamados de cães por Odisseu no momento de sua vingança (Od. XXII.35). Nessa apresentação das servas e dos pretendentes como cães, as características caninas prevalecentes são a

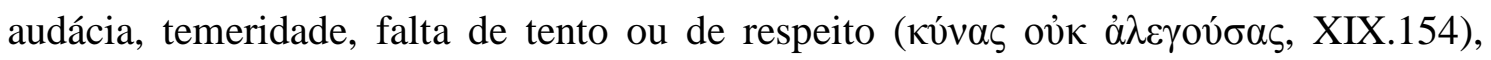




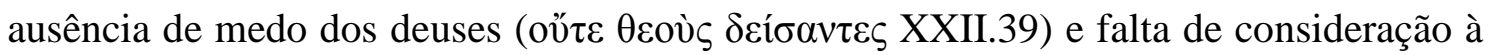
nêmesis dos homens (XXII.40). Esse retrato geral condiz com a definição frequente do

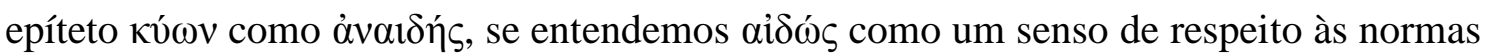
da comunidade, acompanhado de um temor às opiniões alheias ${ }^{32}$. Por vezes, o próprio contexto de uso dos epítetos caninos apoia essa interpretação. No canto primeiro da

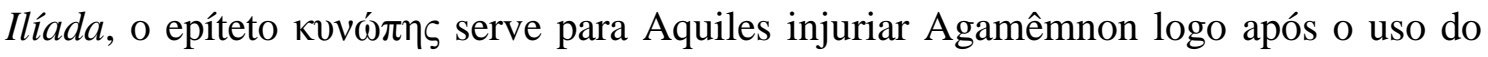
vocativo $\mu \varepsilon \gamma^{\prime} \alpha \dot{\alpha} v \alpha 1 \delta \dot{\varepsilon} \varsigma$ (v. 158-9), assim como na embaixada do canto IX, Aquiles diz

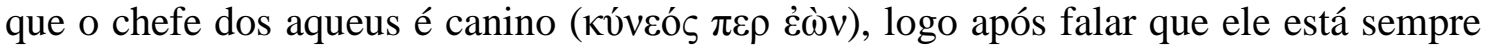
coberto de à $v \alpha i ́ \delta \varepsilon 1 \alpha$ (Il. IX.372-3).

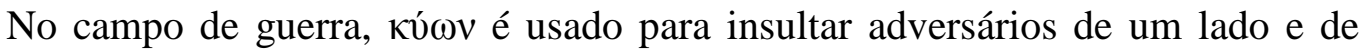

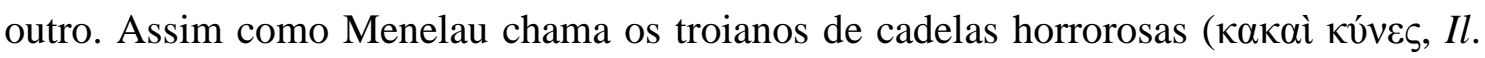
XIII.623), Heitor se refere aos aqueus como cães (Il. VIII.527) e Teucro se queixa da

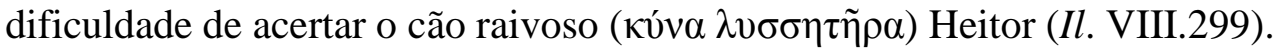

Heitor, aliás, tem momentos caninos bem marcados ao longo da epopeia. Mais tarde, no canto VIII, um símile diz:

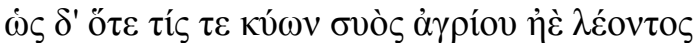

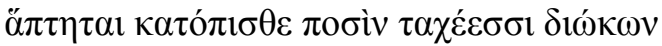

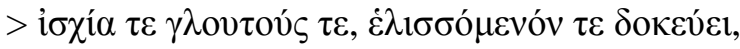

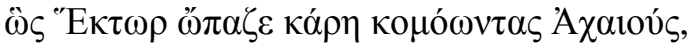

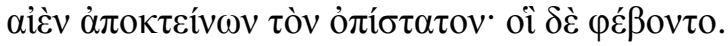

Tal como o galgo que, na perseguição com patas velozes, ao javali ou ao leão toca por trás no flanco ou nas nádegas, e está atento ao momento em que a presa se desvia assim Heitor pressionava os Aqueus de longos cabelos, matando quem ficava pra trás. Eles fugiam, desbaratados ${ }^{33}$.

(Il. VIII.338-42)

Nesse momento, a excelência guerreira de Heitor é ilustrada pela imagem do cão caçador. Compare-se isso ao passo em que Diomedes chama Heitor de cão, depois de

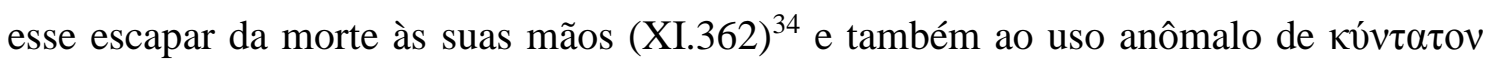
no episódio da Doloneia, quando Diomedes pensa que coisa mais cachorra ele deve fazer entre as façanhas possíveis no acampamento dos trácios (X.503-6). Se na fala de

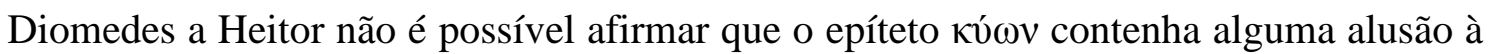

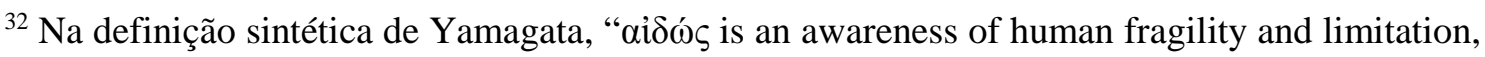
which is necessary to confine oneself within one's measure, one's lot." (1993, p. 174).

${ }^{33}$ Para as citações da Ilíada, utilizo a tradução de Frederico Lourenço (2010).

${ }^{34}$ Todo o bloco de versos 362-7 será repetido por Aquiles no canto XX, v. 449-54.
} 


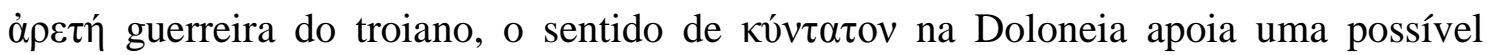
indicação das proezas de Heitor na fala de Teucro mencionada anteriormente

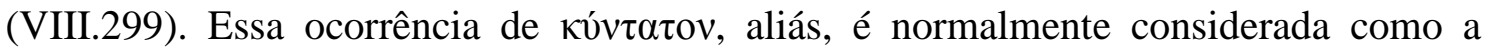
única metáfora canina de Homero com sentido positivo ${ }^{35}$, quando, de resto, o sentido

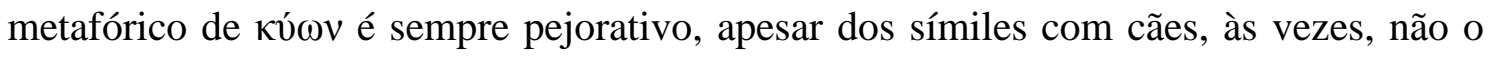
serem.

De todo modo, o momento canino mais marcante de Heitor é quando, um pouco antes de morrer, ele suplica a Aquiles que não lhe deixe ser devorado pelos cães, mas restitua o seu cadáver à sua casa, mediante o devido resgate (Il. XXII.338-43). Aquiles, irado, não apenas nega o pedido, mas também o chama de cão e diz até que gostaria de ter força e ânimo para lhe cortar a carne e comê-la crua (Il. XXII. 345-54). A fala é

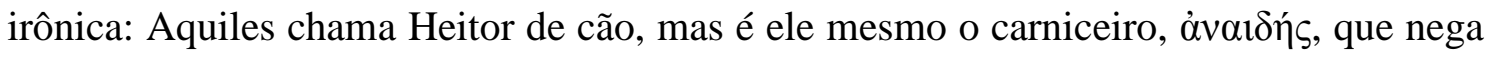
o respeito devido ao cadáver do guerreiro.

Os epítetos caninos também servem para injuriar as deusas Afrodite (Od. VIII.319), Ártemis (Il. XXI.481) e Hera (Il. VIII.423 e XVIII.396). Desses, o caso mais

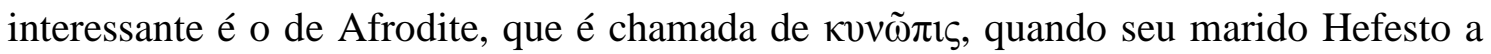
flagra na cama com Ares (Od. VIII.306-20). Os comentadores geralmente mencionam a

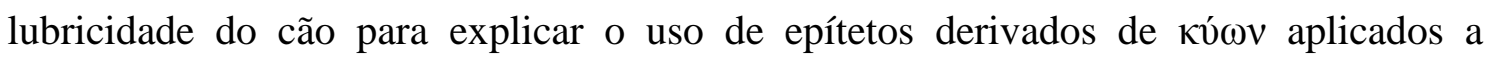
mulheres (deusas ou mortais). Mas me parece que, no contexto homérico, esse episódio é o único em que a qualidade de cão de uma mulher pode ser diretamente relacionada à sua licenciosidade, e, mesmo aqui, esse não é o aspecto principal ${ }^{36}$. Até mesmo no caso emblemático de Clitemnestra, mulher que trai o marido, como a leal Penélope nunca trairá Odisseu, a cadelice da personagem não é associada à luxúria. A fala de Agamêmnon no Hades, ao contrário, sublinha muito mais a traição em termos do assassinato do marido - essa sim obra vergonhosa da esposa mais cadela (Od. XI.40534).

A esse depoimento de Agamêmnon no Hades, Ulisses vai responder que certamente Zeus infligiu duras penas na descendência de Atreu por meio dos conselhos de suas mulheres, já que, além de Clitemnestra traidora, houve também Helena pela

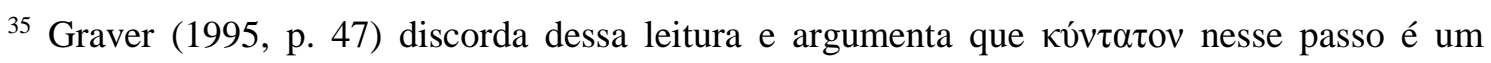
julgamento anômalo do poeta-narrador a uma má ação de Diomedes.

${ }^{36}$ Lefkowitz, por exemplo, argumenta que a misoginia grega está mais relacionada a uma suscetibilidade a paixões destrutivas do que ao próprio desejo sexual (1986, p. 112-26). Aqui a

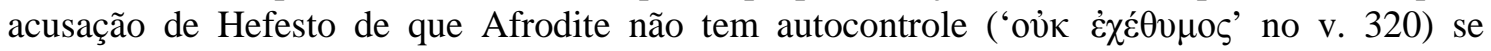
adequa perfeitamente a essa interpretação. 
qual muitos dos aqueus morreram (Od. XI.436-9). É assim também, como motivo da destruição de muitos gregos, que Helena é mencionada pela primeira vez na Ilíada, na fala de Hera (Il. II.161-2).

Antes de a própria Helena entrar em cena na Ilíada, seu nome é evocado três vezes. Primeiro na fala de Hera referida acima, depois no discurso de Nestor, que defende a permanência dos Aqueus na guerra troiana:

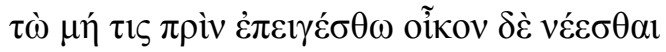

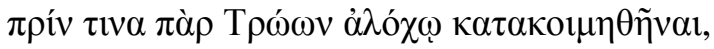

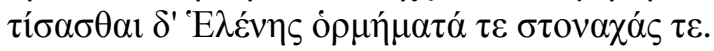

Por conseguinte, que ninguém se apresse a regressar a casa, Antes que ao lado da mulher de algum Troiano tenha dormido, Vingando assim os estrebuchamentos e lamentações de Helena.

(Il. II.354-6)

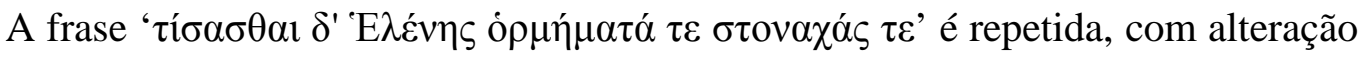
mínima, no catálogo das naus, quando de Menelau é dito que ele se movimentava entre os companheiros incitando-os à guerra, porque desejava no coração "vingar os estrebuchamentos e lamentações de Helena" (Il. II.588-90). O significado da frase é ambíguo, porque gramaticalmente a expressão tanto pode se referir aos estrebuchamentos e lamentações de Helena, quanto aos estrebuchamentos e lamentações dos gregos causados por Helena. Aristarco defendia a segunda leitura, rejeitando uma visão separatista de que Helena seria retratada de maneiras distintas nas duas epopeias homéricas, sendo raptada à força na Ilíada e fugindo voluntariamente na Odisseia. De resto, os comentadores oscilam entre as duas interpretações conforme sejam suas ideias sobre o caráter de Helena na Ilíada ${ }^{37}$.

De todo o modo, a controvérsia de Helena ter ido a Troia à força ou por vontade própria nunca é colocada como questão central em Homero. Em lugar disso,

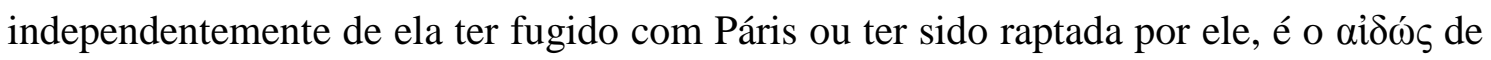
Helena que é o foco principal da apresentação da personagem em Homero. E daí

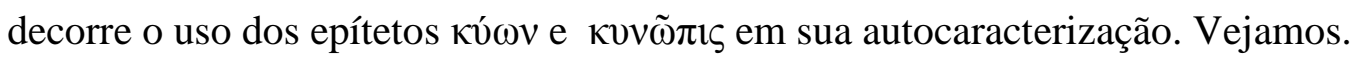

Quando Íris se aproxima de Helena para chamá-la, encontra-a tecendo uma grande e luxuosa tapeçaria, na qual ela bordava as contendas que troianos e aqueus sofriam por sua causa (Il. III.125-9). Por comum que seja a atividade tecelã para

${ }^{37}$ Roisman (2006, p.3), por exemplo, é mais simpática a Helena, Yamagata (1993, p. 22, n. 1) e Kirk (1985, p. 153 e 214) não. 
mulheres em Homero ${ }^{38}$, a autorreferencialidade do bordado de Helena eleva a sua ocupação a um nível mais alto. Com efeito, essa imortalização dos feitos de guerra por meio da tapeçaria remete à própria atividade do aedo, de modo semelhante ao canto metalinguístico de Aquiles no canto IX da Íliada. Em sua primeira aparição, Helena é uma personagem com poder criativo e com capacidade de entender, articular e quiçá escrever a sua própria história ${ }^{39}$. E fazendo isso, Helena começa a assumir para si a sua parcela de responsabilidade na guerra.

O segundo aspecto aparente nesse ponto da narrativa é o pathos da saudade que Helena sente de sua casa legítima, ainda que essa saudade lhe seja lançada no peito pela deusa Íris. Helena, de fato, chora de saudades do marido, da cidade e dos progenitores, enquanto se põe a caminho das Portas Esqueias para assistir ao duelo de Páris e Menelau. A cena seguinte da admiração dos anciãos ante a beleza de Helena (III.154160) eleva a nobreza da personagem ao mais alto nível, pois nem esses sábios, que já superaram a idade das tentações sensuais, são capazes de dizer que o longo sofrimento de troianos e aqueus por uma mulher como Helena seja motivo de indignação (vé $\mu \varepsilon \sigma ı)$ ) 40.

Não são somente os anciãos que demonstram especial deferência a Helena, mas também o rei Príamo a trata como 'querida filha' (Il. III.162 e 192) e lhe diz que a culpa da guerra é dos deuses e não dela. Helena responde a Príamo em tom igualmente gentil e afetuoso:

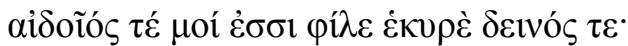

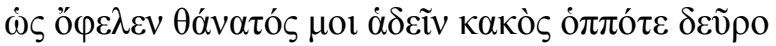

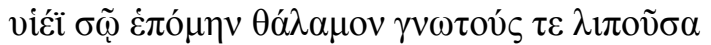

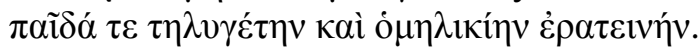

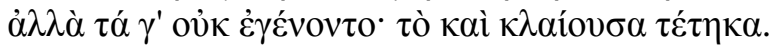

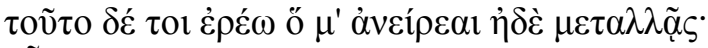

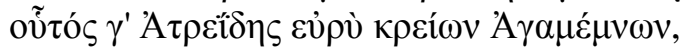

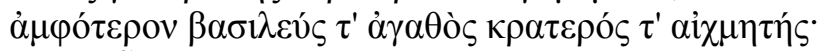

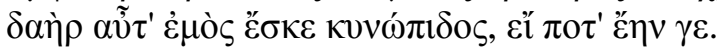

38 Andrômaca (Il. VI.490), Penélope (Od. II.94), Circe (Od. X.221), as ninfas de Ítaca (Od. XIII.107), a deusa Atena (Il. VIII.385 e XIV.178) e a própria Helena, em outras circunstâncias (Od. XV.123), também se ocupam do tear.

${ }^{39}$ Não é o que pensa Kennedy: "Helen is like a camera, picturing in the only way available to her the events on the plain of Troy of which she is not an active part, but at the same time those events result from her being what she is [...]" (1986, p. 9). Para o autor, a cena demonstra a incompetência de Helena em registrar os personagens visualmente, uma incompetência que seria contrastada com o conhecimento e a capacidade verbal reservada ao bardo narrador (KENNEDY, 1989, 12-3).

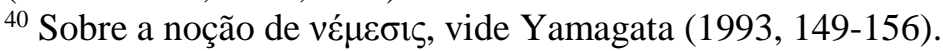


Venerando és tu para mim, querido sogro, e terrível:

quem me dera ter tido o prazer da morte malévola, antes de para aqui vir com o teu filho, deixando o tálamo, os parentes, a minha filha amada e a agradável companhia das que tinham a minha idade: mas isso não pôde acontecer. E é por isso que o choro me faz definhar. Mas responder-te-ei àquilo que me perguntas. Este é o Atrida, Agamémnon de vasto poder, que é um rei excelente e um forte lanceiro. Era cunhado da cadela que sou; se é que foi mesmo.

(Il. III.172-80)

Tratando-o por 'querido sogro', Helena diz que Príamo é aỉoĩos para ela demonstrando verbalmente que tem consciência do $\alpha i \delta \omega ́ \varsigma$ - e, em seguida, avalia pela primeira vez sua própria situação. Entre o lamento por não ter morrido antes de ir a Troia e o primeiro uso do epíteto $\kappa v v \tilde{\omega} \pi \iota \varsigma$, cabe ainda um breve elogio ao rei Agamêmnon. Na Teicoscopia, Helena também vai notar a ausência de seus irmãos Castor e Polux e supor que eles não tenham comparecido por temerem vergonhosos insultos a seu respeito (III.236-42). Até esse ponto, essas primeiras manifestações de Helena apresentam a personagem como alguém que tem consciência e vergonha de sua responsabilidade nos sofrimentos da guerra, ainda que essa responsabilidade, pelo ponto de vista da própria personagem, talvez pareça exagerada, se comparada aos julgamentos de outros, incluindo os sábios anciãos troianos.

As cenas subsequentes amplificam ainda mais o heroísmo de Helena. Ante o ultraje de se unir ao perdedor Páris, Helena ousa desafiar a própria deusa Afrodite, que ela é capaz de reconhecer apesar do seu disfarce (III.399-412). Afrodite tenta atrair Helena descrevendo os encantos do belíssimo Alexandre que acaba de voltar do combate, como se tivesse voltado de uma dança (III.390-4), mas a espartana não apenas resiste a essa tentação sensual, como manda a própria Afrodite ir ao encontro de Páris para ser sua esposa ou escrava, já que a deusa gosta tanto dele. Como observa Roisman (2006, p. 18), a sugestão é ainda mais ofensiva não só porque reduz a deusa ao status de escrava, mas porque a faz escrava de suas próprias paixões, de um modo que a própria Helena não o é. A espartana encerra seu discurso dizendo que não vai voltar para o

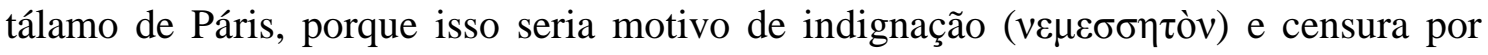
parte das troianas. Mais uma vez, Helena demonstra o zelo apropriado à sua reputação.

Ameaçada por Afrodite, Helena enfim se submete à deusa e vai ao encontro de Páris. Porém não se deita com seu atual cônjuge antes de manifestar o desejo de que ele 
tivesse morrido às mãos de seu primeiro e mais forte marido. Ao final, ela mesma pede que Páris desista do duelo para que não seja vencido, em uma fala que, às vezes, é entendida como ironia sarcástica, às vezes, como sinal da volatilidade de Helena e da ambiguidade dos seus sentimentos (III.428-36).

Mas a próxima aparição da personagem (VI.323 e ss.) vai confirmar o desprezo que Helena sente pelo atual marido. A Heitor, que censura Páris por estar fora da batalha, Helena diz que, em circunstâncias tão ruins, desejaria, ao menos, ter um homem melhor, e não esse (Páris) que não tem o juízo perfeito. Dessa vez, Helena se chama de cadela duas vezes e põe a culpa da guerra primeiro nos desígnios dos deuses, depois em sua própria cadelice e na áte de Alexandre (VI.344-58).

A cena também demonstra uma afeição de Helena a Heitor, que contrasta com o tratamento que ela dispensa ao próprio marido. Com efeito, se no canto terceiro, Helena foi obrigada por Afrodite a se sentar junto de Páris, dessa vez, é a própria Helena, quem chama o cunhado a sentar-se junto de $\mathrm{si}^{41}$. Essa afeição é reiterada na prece funerária sobre o cadáver de Heitor (XXIV.762-75), quando Helena reafirma que preferia ter morrido antes de ir a Troia e diz que então já não há quem lhe seja gentil ou amigo em Troia, mas que é desprezada por todos.

Mas apesar de Helena mencionar que Heitor a defendia dos ataques de seus familiares troianos, nas epopeias homéricas, só há duas únicas menções negativas a Helena feitas por outros personagens que não ela mesma, e ambos são gregos. Uma delas aparece no canto XIX da Ilíada, quando Aquiles diz que combate em Troia por causa de Helena horripilante $\left(\dot{\rho} t \gamma \varepsilon \delta \alpha v \tilde{\eta} \varsigma^{42}\right.$ ), a outra surge no canto XIV da Odisseia, quando Eumeu preferiria que a raça de Helena fosse extinta antes que seu amo morresse longe da pátria (Od. XIV.68-70). No entanto, em ambas as cenas, tanto Aquiles quanto Eumeu assumem atitudes pessimistas em relação a Helena, quando estão diante de desastres causados pela guerra: a perda de Pátroclo, no primeiro caso, a suposta morte de Ulisses, no segundo. Mais do que criticar a própria Helena, Aquiles e Eumeu lamentam a guerra em si e suas consequências, o que de certo modo dá razão aos lamentos de Helena sobre sua má reputação.

\footnotetext{
${ }^{41}$ A bem da verdade, esse chamado, um tanto sedutor, já denuncia uma ambiguidade de caráter de Helena também presente na Íliada, ainda que, no plano mais superficial do texto, essa ambiguidade talvez não esteja tão marcada quanto na Odisseia. Para o caráter de sedução sexual dessa manobra de Helena, vide Graziosi e Haubold, 2010, p. 41-44.

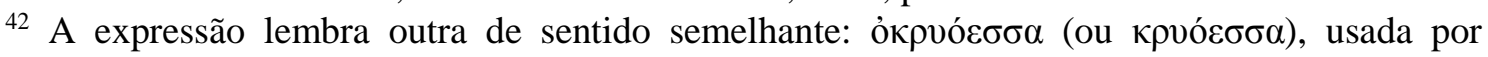
Helena no canto VI (v. 344).
} 
Ao longo da Ilíada, o retrato apresentado da Helena é a de uma mulher, que apesar de cativa e sujeita a várias restrições, inclusive impostas pelos deuses, tem zelo

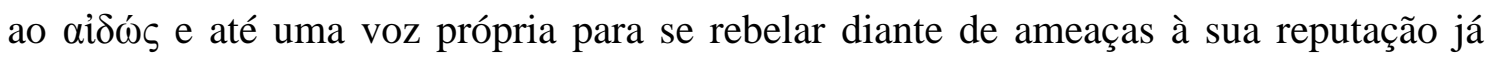
prejudicada. É nesse quadro que se deve entender o uso paradoxal dos epítetos caninos:

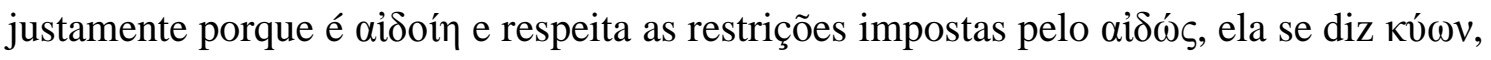

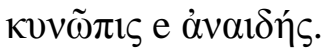

O cuidado com seu nome e a atenção ao $\alpha \mathfrak{i} \delta \omega ́ s$ faz com que, na má fama da Helena homérica, já esteja prevista a tragédia de uma outra Helena, a de Eurípides, que sofre por males causados unicamente à sua reputação. Mas o comprometimento da Helena da Ilíada é mais contundente: se a Helena da tragédia sofre pela má fama imerecida, a Helena da épica sofre simplesmente pela má fama - e a ela nem interessam questões de merecimento.

\subsection{A FARMÁCIA DE HELENA}

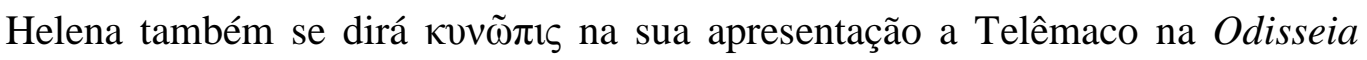
(IV.145-6), mas aí o contexto da declaração é ainda mais complicado, porque aparentemente envolve alguma espécie de discordância ou incoerência entre as histórias de Menelau e Helena sobre a lealdade da espartana ao seu esposo grego em Troia ${ }^{43}$.

Em conformidade com a opulência de Esparta, a primeira aparição de Helena na Odisseia é fortemente marcada pela exuberância de alguns pertences brilhantes e preciosos (IV. 121-137). O estudo de Clader (1976), que investiga as origens de Helena a partir do texto épico, conclui que a personagem, tal como aparece em Homero, é uma síntese de duas antigas divindades: uma deusa indoeuropeia, relacionada ao Sol e aos Dióscuros, e uma deusa da vegetação de origem mediterrânea. Para Clader (1976, p. 5557), o próprio epíteto A $\rho \gamma \varepsilon i ́ n$, onze vezes atribuído a Helena em Homero, deve estar relacionado à mesma raiz de 'à $\rho \gamma o ́ \varsigma '$ ', um adjetivo naturalmente apropriado a figuras de deuses $^{44}$, e, em especial, a uma deusa associada ao Sol e aos Dióscuros ${ }^{45}$. Segundo essa

\footnotetext{
${ }^{43}$ Entre as interpretações dessa cena, destaco as que mais influenciaram minha própria leitura: Olson, 1989, p. 387-394; Austin, 1994, p. 81-3; Schmiel, 1972; Anderson, 1969, p. 73-86; Maniet, 1947, p. 37-46.

${ }^{44}$ Além de Helena, apenas Hera é dita Apycín em Homero (duas vezes).
} 
interpretação, algo de divino já é vislumbrado na primeira aparição de Helena na Odisseia. Assim também, Martin West $(1975 ; 1978)$ chega a conclusões semelhantes sobre as origens da personagem ${ }^{46}$, mas, por ora, é outra indicação sua que nos interessa.

Entre os luminosos apetrechos de Helena, estão uma roca de ouro e um cesto de prata com bordas de ouro, que lhe foram dados de presente por uma certa Alcandra, esposa de Polibo, habitante do Egito (IV. 125-132). Também é egípcia a intrigante droga que Helena usará para aplacar os ânimos dos seus convivas (IV. 220-233). E, um pouco mais adiante, Menelau vai fazer um relato completo sobre as errâncias do casal espartano pelo Egito (IV. 351-586).

É notório que Helena também vá ao Egito em Heródoto (Hist. II. 112-120), Eurípides (Hel.) e, possivelmente, também em Estesícoro (fr. 193 = P. Oxy. 2506, fr. 26, col. i). Para West (1975, p.14), a antiguidade e persistência dessa conexão egípcia no mito de Helena deve estar relacionada a uma viagem mítica da princesa Filha do Sol rumo ao sul, durante o inverno - sendo essa princesa Filha do Sol aquela mesma divindade indoeuropeia que Clader identifica a Helena. $\mathrm{O}$ argumento de West é que o Egito serviria como destino ideal para o retiro de inverno de uma divindade relacionada aos movimentos do sol, porque, por muito tempo, esse país foi a mais longínqua região ao sul conhecida pelo gregos.

Mesmo que essa motivação mítica da viagem ao Egito seja verdadeira, é certo que, nas versões da poesia e depois da prosa, são outras variáveis que prevalecem. Um traço descritivo constante nas descrições gregas do Egito é sua abundância. Abundância não só de bens materiais, mas também de conhecimento e sabedoria. Em paralelo ao esplendor dos presentes ofertados a Helena e Menelau na Odisseia (Od. IV. 125-32), a única referência ao Egito na Ilíada diz respeito exatamente à riqueza da cidade de Tebas (Il. IX. 379-86). E assim também, na Helena, quando Teucro chega ao Egito, as suas primeiras palavras são de admiração ante à opulência do palácio de Proteu, que ele chega a comparar à morada do próprio Pluto (Eur. Hel. 68-70). Principalmente a partir de Heródoto, prevalecerá, em definitivo, a representação da religião egípcia como fonte primordial de sabedoria e dos rituais ${ }^{47}$. O prestígio dessa cultura egípcia será tão alto

\footnotetext{
${ }^{45}$ Clader vai mais além sugerindo que a própria Argos que Menelau diz governar (IV. 174) não deve ser identificada à Argos histórica, mas a algum luminoso reino lendário (1976, p. 57).

${ }^{46}$ Para uma crítica dessa interpretação de West e Clader, vide Brillante (2002, p. 46-7).

${ }^{47}$ Bowman, 2002, p. 203. Heródoto chega a derivar do Egito os próprios nomes dos deuses (II. 50), além das procissões (II. 58), dos mistérios religiosos (II. 49, 51, 81,171), da crença na metempsicose (II. 109) e da geometria (II. 109).
} 
nos séculos seguintes que fará do país um destino de peregrinação e turismo cultural ${ }^{48}$ peregrinação que, aliás, pode ser real, ou fictícia, como nos relatos das biografias

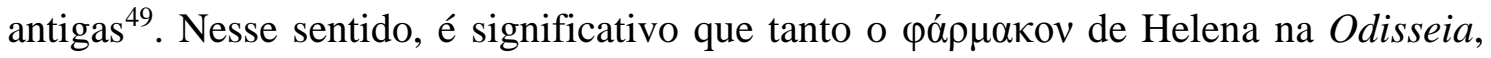
quanto a capacidade divinatória da profetisa Teônoe na Helena estejam tão intimamente relacionados ao Egito e à sabedoria luxuriante desse país ${ }^{50}$.

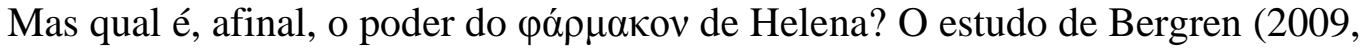

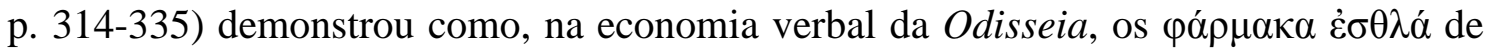

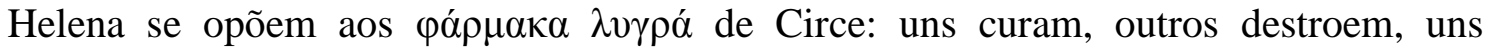
prometem fazer esquecer todos os males, possibilitando uma continuidade mais ou menos tranquila à noite, outros fazem esquecer totalmente a terra pátria, ameaçando $o$ retorno dos heróis:

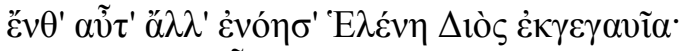

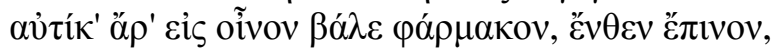

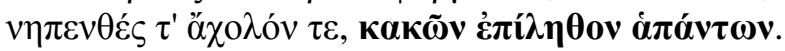

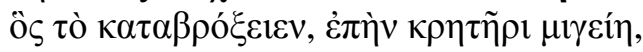

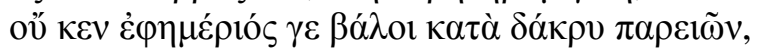

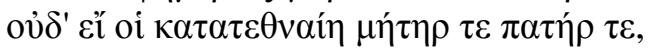

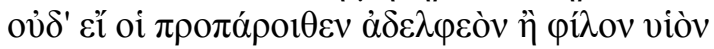

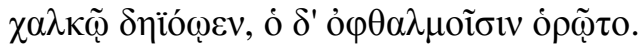

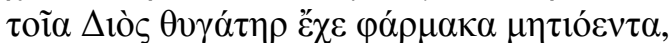

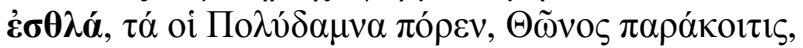

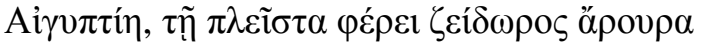

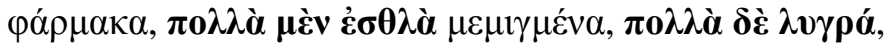

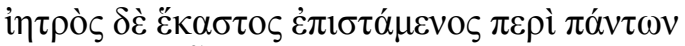

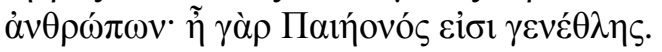 \\ Outro feliz parecer teve Helena, de Zeus oriunda: \\ deita uma droga no vaso do vinho de que se serviam, \\ que tira a cólera e a dor, assim como a lembrança dos males \\ Quem quer que dela provasse, uma vez na cratera lançada, \\ não poderia chorar, pelo menos no prazo de um dia, \\ mesmo que o pai e a mãe cara privados da vida ali visse, \\ ainda que em sua presença, com o bronze cruel, lhe matassem \\ o filho amado ou o irmão e que a tudo ele próprio assistisse. \\ Tão eficazes remédios a filha de Zeus possuía, \\ e salutares, presente da esposa de Tão, Polidamna,
}

${ }^{48}$ Bowman, 2002, p. 205. Como traço mais ou menos constante na representação do Egito pelos gregos, Bowman também menciona a proeminência do país como cenário de ficção romantizada ou idealizada (p. 202).

${ }^{49}$ Lefkowitz, 2007, p. 101-111.

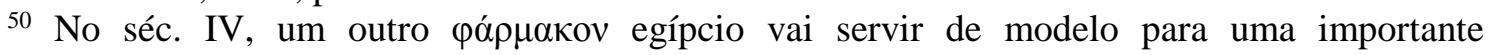

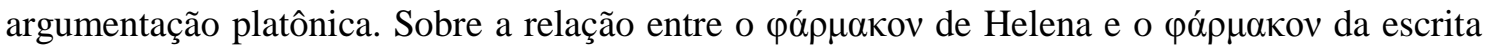
de Platão, ver especialmente Gagnebin 1997, p. 49-67. No Fedro, o aspecto negativo do

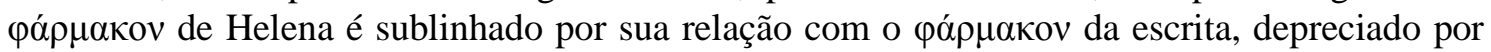
Tamuz/Platão. 
da terra egípcia, onde o solo frugífero gera abundantes drogas, algumas benéficas, outras fatais nos efeitos. Todos os homens são médicos lá, distinguindo-se muito, pelo saber, dos demais, pois descendem da raça de Péone.

(Od. IV. 219-32)

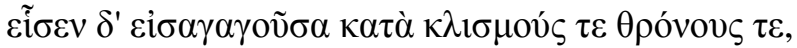

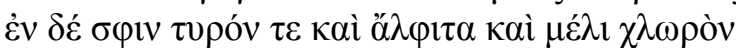

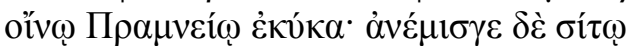

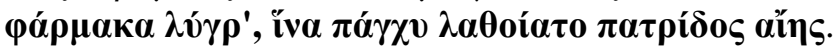

Ela [Circe] os levou para dentro e of'receu-lhes cadeiras e tronos, e misturou-lhes, depois, louro mel, queijo e branca farinha em vinho Prâmio; à bebida, assim feita, em seguida mistura droga funesta, que logo da pátria os fizesse esquecidos.

(Od. X. 233-6)

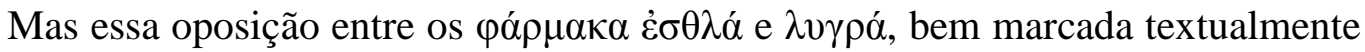

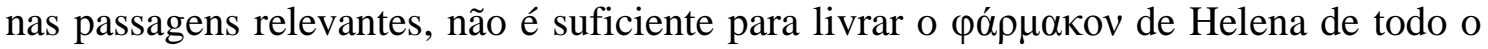
risco de intoxicação. E isso se não por seu potencial de esquecimento destrutivo, talvez pela demonstração prática de seus efeitos que virá a seguir.

Após misturar a droga egípcia ao vinho, Helena usa ainda um outro expediente para apaziguar os ânimos dos seus convivas: ela conta uma história. A identificação do

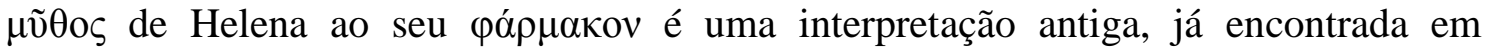
Plutarco (Quaestiones Conviviales 614c) e Macróbio (Saturnalia 7.1.18). O problema

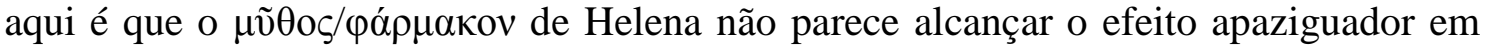
nenhum de seus dois principais ouvintes, Menelau e Telêmaco.

Com efeito, na sua história, Helena conta como foi cúmplice da embaixada secreta de Odisseu em Troia, banhando-o e não denunciando sua presença, quando ele, disfarçado, adentrou a cidade inimiga como espião e depois partiu matando muitos troianos. Além de antecipar alguns movimentos futuros da Odisseia - o disfarce de Odisseu em Ítaca, o banho dado por Euricleia e o massacre dos pretendentes -, esse $\mu \tilde{v} \theta$ o $\varsigma$ de Helena serve para conferir $\kappa \lambda \varepsilon$ ćs tanto a Odisseu quanto à própria narradora, que, segundo ela mesma, é a única capaz de reconhecer o herói em seu disfarce. Para coroar, o relato de Helena termina com uma declaração de preferência a Esparta ante a Troia e com um elogio ao marido abandonado.

Na sequência, Menelau também vai contar uma história para enaltecer Odisseu $\tau \alpha \lambda \alpha \sigma i ́ \varphi \rho \omega v$, só que, dessa vez, ao invés de aparecer como aliada, Helena será justamente o perigo a ser evitado, e evitado apenas graças à capacidade única de Odisseu de reconhecê-la em suas várias imitações das vozes das esposas dos aqueus. 
Uma referência en passant à companhia de Deífobo (Od. IV. 276), com quem Helena teria se casado após a morte de Páris, aumenta ainda mais as suspeitas acerca da lealdade da espartana a Menelau e ao partido dos gregos.

Como observa Goldhill, as histórias de Helena e Menelau não são apenas concorrentes, mas também suplementares, operando um jogo de repetição e diferença (1999, p. 421). O que fica em aberto é qual seja exatamente o efeito da droga sobre Menelau: será que foram os encantamentos de Helena, farmacêuticos e narrativos, que permitiram que a justaposição dessas histórias ocorresse a Menelau sem mágoa ou conflito? Ou deve-se, ao contrário, perceber uma tensão latente nas entrelinhas de seu

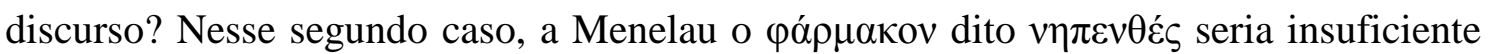
para sossegar as mágoas causadas pelo rapto de Helena e suas consequências.

A resposta de Telêmaco, por outro lado, é inequívoca. 'A $\lambda \gamma$ rov!, ele exclama, e pede para se retirar ${ }^{51}$. É com uma expressão de dor aumentada (o grifo é de Goldhill) que o filho de Odisseu recebe as histórias do casal espartano, como se nenhuma droga analgésica tivesse surtido efeito nele e como se as histórias de Helena e Menelau, como

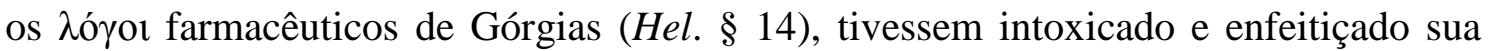
$\operatorname{alma}^{52}$

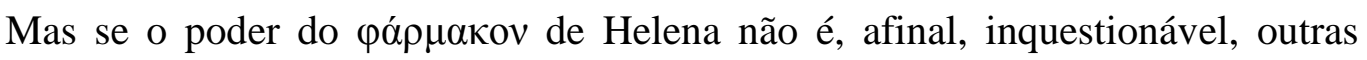
habilidades suas ficam bem evidentes na cena do canto IV. Em sua história, apesar de não explicar como o faz, Helena é a única em Troia a reconhecer Odisseu disfarçado, um reconhecimento que, aliás, parece tão imediato quanto aquele de Argos e Odisseu. Já o relato concorrente de Menelau expõe a habilidade extraordinária de Helena de imitar as vozes de todas as esposas dos guerreiros gregos escondidos no cavalo de madeira, depois de ter sido capaz de reconhecer também que o cavalo de madeira era um estratagema.

${ }^{51}$ Od. IV. 292-3: “Ó Menelau, de Atreu filho, discíp’lo de Zeus, chefe de homens, tanto pior (ä $\lambda \gamma 10 v)$ ! Tal virtude não pôde livrá-lo da Morte ( $\lambda v \gamma \rho o ̀ v ~ o ̈ \lambda \varepsilon \theta \rho o v)$, nem que tivesse no peito a bater coração inquebrável.

Ora nos manda deitar, que no leito macio possamos sob a coberta do sono agradável gozar do repouso."

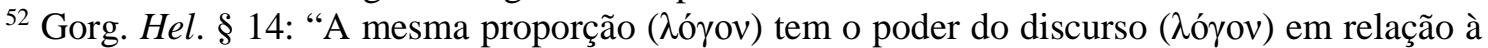
disposição da alma e o poder dos remédios em relação à fisiologia dos corpos. Pois como certos remédios expulsam certos humores do corpo, e, enquanto alguns dão fim à doença, outros dão fim à vida, assim também são os discursos, uns causam dor, outros deleite, uns atemorizam, e outros incitam os ouvintes à coragem, e outros, por meio de alguma persuasão maligna,

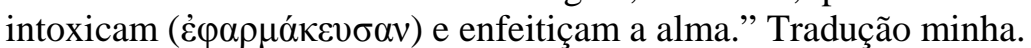


Boyd (1998, p. 4) salienta ainda que, além de reconhecer Odisseu, Helena é a única personagem da Odisseia capaz de fazê-lo admitir sua identidade, contra a sua vontade, colocando-o assim em seu poder. O mesmo autor chama atenção para o caráter encantatório das ações de Helena na história troiana contada por Menelau: são três as vezes que ela rodeia o cavalo de madeira, um número potente para encantamentos, e, enquanto o faz, ela também toca o artefato, em um gesto possivelmente encantatório (BOYD, 1998, p. 8-9).

Para além da heroína que se acusa e se lamenta pelos sofrimentos causados pela guerra, a Odisseia põe em relevo alguns poderosos dons de Helena, que amplificam uma ambiguidade de caráter da personagem presente nas mais diversas narrativas. É, pois, de modo análogo que, na segunda metade da tragédia Helena, a concepção, direção e atuação num sangrento plano de fuga parecem de certo modo se opor à passividade e ao clima de lamentação em que a personagem principal iniciou o drama ${ }^{53}$.

Contudo, não é apenas no comportamento ambíguo de suas Helenas que residem as semelhanças entre a Odisseia e a Helena. De fato, a esposa fiel da tragédia de Eurípides pode parecer, à primeira vista, mais próxima de Penélope do que da Helena do ع̈ $\pi$ o tradicional.

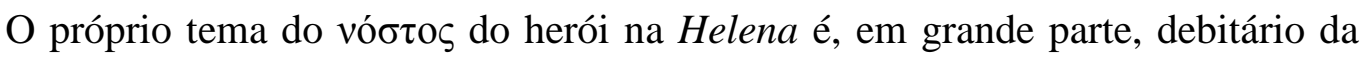
narrativa da Odisseia, e são numerosos os paralelos entre as duas histórias ${ }^{54}$. Tanto na Helena como na Odisseia, os heróis chegam em seus lares desconfiados de suas mulheres, Odisseu por advertência de Agamêmnon, Menelau por acreditar ter sido traído, mas ambos encontram esposas fiéis após prolongada ausência. Nas duas narrativas, um exilado errante fala do marido à esposa fiel, Teoclímeno na Odisseia (XVII. 151-16), Teucro na Helena (v. 132). Ambos os casais também têm uma cena de reconhecimento em que, a princípio, uma das partes se nega a reconhecer a outra. $\mathrm{O}$ reencontro do casal na tragédia, aliás, reflete uma cena da Odisseia. Quando veem Menelau, Helena e o coro temem o estranho seminu, assim como Nausícaa e suas acompanhantes temeram o náufrago Odisseu. Na Helena, o coro estava secando peplos quando ouviu o grito de Helena, na Odisseia, analogamente, Nausícaa e suas servas lavavam roupas e jogavam bola quando acordaram Odisseu.

\footnotetext{
${ }^{53}$ Juffras, 1993.

${ }^{54}$ Uma reunião bastante ampla desses paralelos foi feita por Eisner em seu artigo Echoes of the Odyssey in Euripides' Helen (1980). Em língua portuguesa, a Profa. Maria de Fátima Sousa e Silva também explorou esses paralelos em seu Ecos da Odisseia na Helena de Eurípides (2004), que, aparentemente, não tem conhecimento do texto de Eisner.
} 
Também já está na narrativa homérica o precedente egípcio para a história de Helena e Menelau (Od. IV. 354 ss.), que também já aparece em Heródoto (II. 113-120) e Estesícoro. Profundamente original, a tragédia de Eurípides reelabora e ressignifica motivos tradicionais, modificando alguns traços, mas cultivando outros. Entre eles, a ambivalência fundamental de Helena.

Similarmente, a Odisseia e a Helena têm heróis náufragos em terras semimágicas, heróis importantes que precisam assumir papéis de suplicantes e mendigos. Mas ainda que semelhantes, esses heróis também são muito diferentes. Em matéria de dotes intelectuais, por exemplo, Menelau está muito aquém de Odisseu, e é Helena quem tem que assumir a função de estrategista para o bom desenrolar da trama. É criação pessoal da esposa o plano que engana Teoclímeno e possibilita a fuga do casal. Mais ou menos, como se a tragédia de Eurípides começasse com uma HelenaPenélope e terminasse como uma Helena-Odisseu.

\subsection{FANTASMAGORIA}

"Si c'est aimer que de suivre un bonheur qui me fuit..." Sonnets pour Hélène, Pierre Ronsard

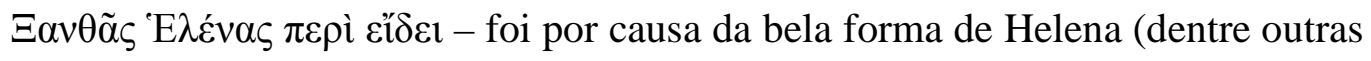
coisas), diz Íbico, que Troia foi destruída (fr. S 151 Dav.). Não por Helena, mas pela forma de Helena. A diferença talvez seja pouco pertinente para a interpretação do fragmento em questão, mas parece mais relevante, se considerada no contexto do mito. Para um certo ramo da tradição, representado em nossas fontes por Estesícoro e Eurípides, a ênfase na beleza de Helena é tamanha que, deposto de sua corporalidade mais palpável, seu $\varepsilon \tilde{i} \delta o \varsigma$ é apenas $\varepsilon \Uparrow \delta \omega \lambda o v$ - imagem quase imaterial, formada de elemento sutil, etéreo ou celeste, mas, nem por isso, menos real.

Boa manobra para os defensores: descolar a beleza maléfica de Helena de sua pessoa e culpar aquela das consequências do rapto e da expedição de resgate, enquanto a Helena em si - qual? - permaneceria intocada, inocente e até mesmo santa. Mas a operação tem uma dificuldade aparentemente incontornável: como apagar ou neutralizar 
essa bela imagem ${ }^{55}$, que é ilusória e quase abstrata em sua superlativação ${ }^{56}$, mas tão viva e resplandecente em suas aparições? Como alcançar o que seja essa Helena sem Helena, que não tem exatamente o que a define? Em outras palavras, existirá de fato uma pessoa perdida sob os espessos véus do desejo? Operação realmente muito difícil: nem Estesícoro, nem Eurípides foram capazes de executá-la com sucesso ${ }^{57}$.

É arriscado tirar grandes conclusões sobre a Palinódia de Estesícoro, já que apenas um fragmento, transmitido pelo Fedro, é atribuído a ela sem contestação (fr. 192 $P M G)$ :

\begin{tabular}{|c|c|}
\hline 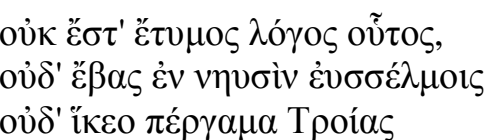 & $\begin{array}{l}\text { Não é correta }{ }^{58} \text { esta história: } \\
\text { não partiste nas naus de belos bancos } \\
\text { nem alcançaste a cidadela de Troia... }\end{array}$ \\
\hline
\end{tabular}

Os testemunhos antigos, por outro lado, são abundantes e até admitem algumas variações $^{59}$. Em geral, como no Fedro, diz-se que Estesícoro teria ficado cego ao blasfemar contra Helena em um poema (Helena), mas depois teria reconhecido seu erro e composto um canto de retratação (Palinódia), que acabou lhe rendendo a recuperação da visão. Um papiro publicado em 1962 (P. Oxy. 2506, fr. 26, I = fr. $193 P M G$ ) complicou ainda mais o estado da questão ao afirmar a existência de duas palinódias, ao invés de apenas uma, sendo uma delas contra Homero, e a outra contra Hesíodo. O autor desse comentário não é identificado no fragmento, mas se apoia na autoridade de Camaleão e é capaz de citar os versos iniciais de cada uma das palinódias. Desde então, os críticos se dividem quanto ao número de palinódias e o teor de cada uma delas ${ }^{60}$. Uma proposta interessante e econômica foi elaborada por Adrian Kelly (2007). Para ele,

${ }^{55}$ Diz Helena: "Ah, se eu pudesse ser apagada, como uma pintura, / e tomasse outra forma, uma

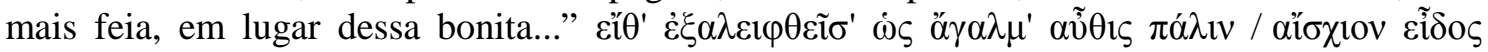

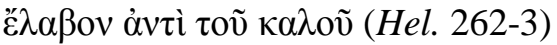

${ }^{56}$ Em Homero, a beleza de Helena nunca é descrita, mas apenas sugerida em expressões como

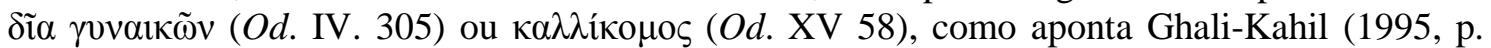
26).

${ }^{57}$ São dessa opinião Bassi (1993) e Juffras (1993), sobre os textos de Estesícoro e Eurípides, respectivamente. Argumentos das duas autoras serão recordados ao longo da exposição.

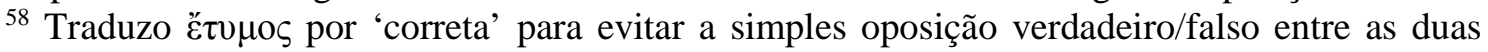
narrativas de Estesícoro e para explicitar o seu sentido de "verdade verificável na realidade". Sobre isso, vide Blaise (1995, p. 31-4.) e Levet (1976, p. 161-5).

${ }^{59}$ Para uma reunião desses testemunhos, vide Page (1962, p. 104-5).

${ }^{60}$ Entre os que duvidam da existência de duas palinódias estão Woodbury (1967), Bertini (1970) e Sider (1989), entre outros. Dão crédito ao testemunho do fr. 193: Bowra (1963), Doria (1963), Devereux (1973), Pulquério (1973-1974), Cingano (1982), Cingano e Gentili (1984) e Cerri (1993), entre outros. 
as histórias da cegueira e da retratação de Estesícoro são traços de uma mesma persona poética restrita a um único poema sobre Helena, e as vicissitudes de transmissão podem explicar a confusão dos nossos testemunhos.

Contudo, se os contornos mais básicos dessa narrativa estesicoreia são incertos, mas ainda o é o sentido global da história. Uma interpretação pode colocar maior ou menor ênfase nos aspectos: a) religioso, da revelação da divindade de Helena; b) político, caso se pense que a Palinódia seja uma variante espartana do mito; c) ou poético, com atenção especial para a crítica da versão homérica, hesiódica ou épica da história. O certo é que a retratação de Estesícoro envolvia um castigo divino e um

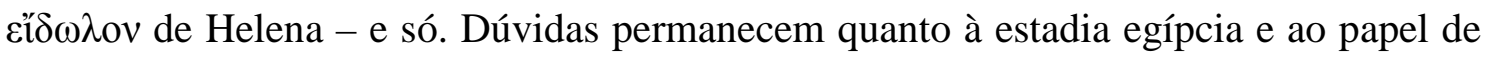
Proteu na história, assim como quanto à possibilidade de adultério ou absolvição total de Helena, o que manteria ou não a ambiguidade tradicional do caráter da personagem $^{61}$.

De todo modo, está claro que o discurso de negação de Estesícoro tem efeitos adversos, como explica Karen Bassi, com atenção à tentativa de castificar Helena:

A Palinódia conta uma "dupla história", em que a negação da culpabilidade feminina é simultaneamente (e mais convincentemente) sua afirmação, em que a reivindicação de estar contando a "verdadeira história" sobre Helena de Troia sacrifica sua própria credibilidade, em que o que parece ser uma subversiva revisão da tradição grega é simultaneamente sua reinscrição. (1993, p. 52)

Uma exploração total das implicações da existência do $\varepsilon \Uparrow \delta \omega \lambda o v$ vai aparecer apenas na Helena de Eurípides. Antes disso, porém, a reputação da beleza exemplar de Helena ainda vai reverberar em outros poetas arcaicos, notadamente nos lésbicos Alceu e Safo.

É curioso que, no mesmo volume dos Oxyrhynchus Papyri de 1914, tenham vindo à tona, pela primeira vez, os fragmentos $16 P M G$ de Safo e $42 P M G$ de Alceu: dois poemas de poetas possivelmente contemporâneos, escritos no mesmo dialeto, usando o mesmo metro e a mesma estrutura de composição em anel, sobre o mesmo exemplo mítico de Helena, porém com percepções muitíssimo diferentes. Cito o fragmento sáfico:

${ }^{61}$ Fredricksmeyer (1996, p. 108-119). 


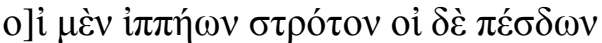

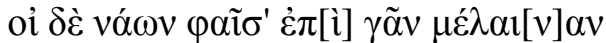

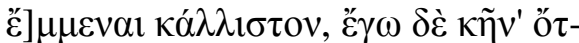
$\tau \omega \tau \imath \varsigma \stackrel{\varepsilon}{\rho} \alpha \tau \alpha \imath^{\circ}$

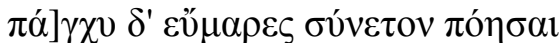

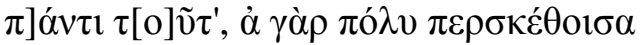

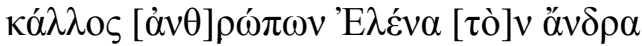

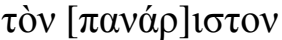

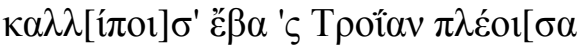

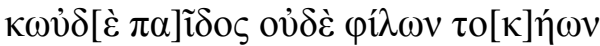

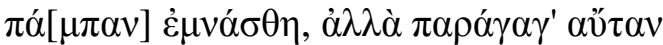
] $\sigma \alpha v$

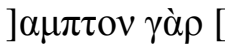

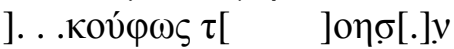

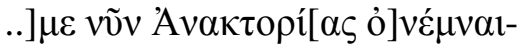
$\sigma^{\prime}$ ở] $\pi \alpha \rho \varepsilon o i ́ \sigma \alpha \varsigma$

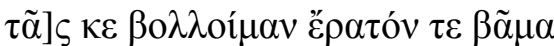

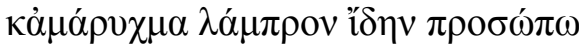

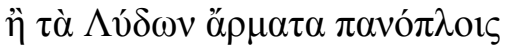
$\pi \varepsilon \sigma \delta \mathrm{o} \mu] \alpha \dot{\chi} \chi v \tau \alpha \varsigma$.
Uns, renque de cavalos, outros, de soldados, e outros, de naus, dizem ser sobre a terra negra a coisa mais bela, mas eu (digo): o que quer que se ame.

Inteiramente fácil tornar compreensível a todos isso, pois a que muito superou em beleza os homens, Helena, o marido o mais nobre,

tendo deixado, foi para Tróia navegando, até mesmo da filha e dos queridos pais de todo esquecida, mas desencaminhou-a (..)]

] (...) pois [

] (...) [

] (...) agora traz-me Anactória à lembrança, a que está ausente,

Seu adorável caminhar quisera ver, e o brilho luminoso de seu rosto, a ver dos lídios as carruagens e a armada infantaria. ${ }^{62}$

Procurando provar que a coisa mais bela sobre a terra é o que quer que se ame, o poema usa de uma lógica um tanto esquisita que dá justamente àquela que superou a todos em beleza a autoridade para decidir o que seja mais belo. Ao fazê-lo, o fragmento concede subjetividade a quem mais comumente (mas não sempre) é tido como mero objeto de desejo. Por essa razão, duBois (1996) exalta o papel ativo de Helena nesse poema, mas é preciso notar a mudança operada no verso 11, quando a personagem é referida no acusativo $\alpha \hat{\tau} \tau \alpha v$ como tendo sido desencaminhada por alguém, possivelmente por Afrodite.

Do exemplo mítico de Helena, que de coisa desejada aparece como pessoa que deseja, a persona poética se volta ao seu próprio desejo. Nas estrofes segunda e terceira, o poema conjuga os motivos do desejo e do abandono, ao dizer que Helena, conduzida pelo desejo, abandonou o melhor dos maridos, a filha e os pais amados ${ }^{63}$. Sem nunca citar Páris, a história da paixão de Helena faz a persona poética se lembrar de

${ }^{62}$ O texto grego é de Page (1987, p. 53), e a tradução é de Ragusa (2005, p. 438-9) com omissão dos versos finais do papiro, que talvez não façam parte do mesmo poema e estão em estado muito fragmentário.

${ }^{63}$ A passagem tem ecos homéricos, identificados por Rissman (1983, p. 41-2): Il. III.172-175 e Od. IV. 261-264. 
Anactória, que está ausente, mas é presentificada pela descrição do seu adorável caminhar e do brilho luminoso de seu rosto. A persona poética, nesse momento, é como a própria Helena em seu ato de desejar, mas é também como Menelau por ter sido igualmente abandonada. E Anactória, ao mesmo tempo, também é um pouco como Helena, que é bela e que abandona. Mas, diferente da bela forma de Helena, a qualidade da beleza de Anactória é especificada na descrição do seu rosto e de seu caminhar, enquanto a beleza de Helena, como de costume, é mera superlativação.

Loraux (1989, p. 235) chama atenção para a profusão de termos neutros dos quais a tragédia e a épica se utilizam para falar da beleza de Helena: ó $\gamma \alpha \lambda \mu \alpha$, $\kappa \alpha \lambda \lambda i ́ \sigma \tau \varepsilon v \mu \alpha, \tau \varepsilon \dot{\varepsilon} \rho \alpha \varsigma, \theta \alpha \tilde{u} \mu \alpha, \pi \tilde{\eta} \mu \alpha \ldots$... Assim mencionada, Helena é claramente tratada como mero objeto, e objeto quase sempre ilusório, porque definido pelo desejo.

Decerto que foco no fr. 16 não é fazer um julgamento moral dos atos de Helena, mas o poema não deixa de apresentar um retrato da personagem mais simpático do que o habitual, bem mais favorável do que o de Alceu, por exemplo, que imputa a Helena a culpa pela destruição dos frígios ${ }^{64}$.

Quanto à Helena, à primeira vista, no seu monólogo inicial (vv. 1-67), a peça parece promover a absolvição total da personagem título. No Egito, por culpa de intrigas divinas, Helena foi mantida a salvo, enquanto gregos e troianos lutavam por um simulacro, que Páris levou a Troia pensando ser a Helena original. Helena se apresenta então como uma esposa fiel e casta, que é injustamente acusada de uma traição que não cometeu. Ela chega a dizer explicitamente quais foram os desígnios de Zeus que realmente causaram a guerra de Troia: aliviar a mãe terra da enorme multidão de mortais, um motivo que retoma o fr. 1 Bernabé/Davies da Cípria, e também celebrizar o mais poderoso dos aqueus (v. 39-41).

Menelau eventualmente vai aparecer no Egito para salvar sua esposa. Mas não que ele estivesse lhe procurando, ao contrário disso, com o عið $\omega \lambda$ ov capturado em Troia sob sua posse, Menelau pensa já ter recuperado a Helena verdadeira. E é aí que a

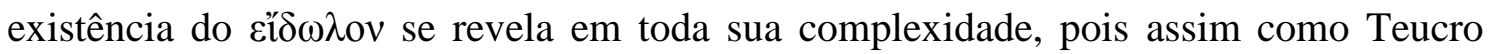
fizera no prólogo (vv. 68-163), Menelau, quando reencontra a verdadeira Helena, não

\footnotetext{
${ }^{64}$ Race apresenta uma comparação interessante desses dois textos, defendendo que os valores cívicos, em Alceu, são superiores aos sentimentos subjetivos, prevalecentes em Safo (1989, p. 16-33). Em sua composição em anel, o fr. $42 P M G$ começa e termina com Helena, que não recebe nenhuma qualificação específica, mas é contraposta à donzela delicada ( $\pi$ á $\rho \theta \varepsilon v o v$ $\alpha ́ \beta \rho \alpha v)$ desposada pelo eácida. Helena serve aqui como um contraexemplo de comportamento feminino, além de poderoso símbolo de destruição.
} 
consegue reconhecê-la como tal, porque mais o convence sua própria trajetória de busca pela imagem de Helena do que a presença material do corpo ${ }^{65}$ de Helena diante de si ${ }^{66}$.

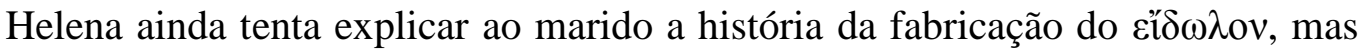
seu esforço é vão (vv. 582-93). Para que Menelau não vá embora desprezando sua verdadeira esposa e o reconhecimento entre os cônjuges aconteça, vai ser necessária

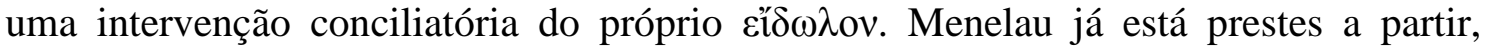
quando entra um mensageiro:

SERVO.

Menelau! Eis que te encontro, depois de muito procurar!

Vaguei por toda esta terra bárbara, enviado pelos companheiros que foram deixados para trás.

ME. Mas o que há? Não fostes vós roubados por esses bárbaros, [fostes?

SE. É admirável, ainda que o seja menos de nome do que de fato.

ME. Diga, pois pela pressa, é algo de inopinado o que te traz.

SE. Digo que foi em vão que suportaste incontáveis penas.

ME. Lamentas por sofrimentos já antigos. E de novo, o que trazes?

SE. Partiu tua esposa, arrebatada, em segredo, pelas dobras do éter. Está escondida no céu, depois de ter deixado a reverenda caverna onde a guardávamos com as seguintes palavras: "Ó infelizes frígios e todos vós, aqueus: por mim, junto às margens do Escamandro, dia após dia, vós seguíeis morrendo por força das maquinações de Hera, imaginando que Páris possuía Helena, quando não possuía.

E eu, depois de ter permanecido pelo tempo que era necessário, e tendo garantido o que estava destinado a acontecer, vou-me embora ao céu, meu genitor. A infeliz tindárida ouviu injustas maledicências, de nada tendo culpa." Ah! olá, filha de Leda! Então era aqui que estavas! Contava eu como tu tinhas partido pelos recônditos estrelares, porquanto não soubesse nada do corpo alado que tens. Não permito que tu zombes de nós novamente, já que em Troia já contribuíste com penas o suficiente para o teu marido e

(Hel. 597-621)

[companheiros.

${ }^{65}$ Versos 559 e 577.

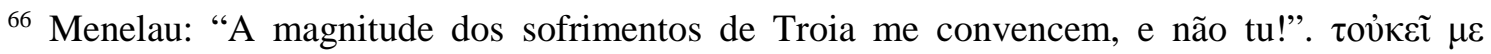

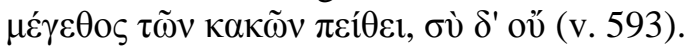




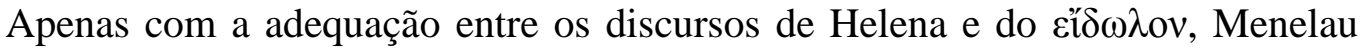
enfim reconhece sua esposa ${ }^{67}$. Mas a fala do servo ainda é pesadamente irônica: com menos elementos para compreender a história inteira, ao ver Helena, ele próprio ainda não consegue distingui-la de seu $\varepsilon \nmid \delta \omega \lambda o v$.

Com o reconhecimento completado, os esposos não deixam de enfrentar dificuldades para voltar para casa, e o que o desenrolar da trama deixa claro é que essa Helena de carne e osso, ainda que esteja em contraposição a uma Helena ilusória e enganadora, também sabe ludibriar e trair. Enquanto Menelau, diante do perigo iminente de ser derrotado pelo tirano Teoclímeno, adota a postura, um tanto inadequado, do herói disposto a gloriosamente morrer em combate, Helena está pronta para preparar um ardil que engane o inimigo e possibilite a fuga dos dois. Por sua própria experiência, Helena sabe que um comportamento exemplar mantido no longínquo Egito não costuma ser recompensado por nenhum $\kappa \lambda \varepsilon \dot{\varepsilon}$ s positivo no mundo dos heróis gregos. Esquecimento e morte é o que predomina no Egito, como o indicam o longo abandono de Helena, o túmulo onipresente de Proteu e principalmente os ecos do rapto de Perséfone e a sutil identificação de Teoclímeno a Hades ${ }^{68}$.

Wolff $(1973$, p. 77$)$ fala em uma assimilação da Helena antiga pela nova ${ }^{69}$. Para Juffras,

[...] nós também somos deixados com duas Helenas: uma, a nova Helena com que a peça começou, a esposa inocente que nunca foi a Troia e que sofreu suas próprias perdas como resultado da guerra; a outra, a Helena que afinal não sofreu muito mesmo, a Helena para quem as consequências da guerra são reversíveis e que, na execução de sua fuga, parece a Helena antiga. (2003, p. 57).

Karsaï, por sua vez, argumenta que a mudança de caráter de Helena é o principal tema dessa tragédia (1998, p. 310). Decompondo a personagem em duas, o autor defende que a história da Helena de Troia é uma história de passividade, enquanto a Helena do Egito seria uma heroína ativa, ardilosa e inteligente. Ainda para Karsaï, a mudança de caráter da personagem aconteceria perante a negação da genealogia divina

\footnotetext{
${ }^{67}$ Coelho, 2001, p. 85; Brillante, 2002, p. 151.

${ }^{68}$ No v. 69, Teucro julga o palácio de Teoclímeno como digno do próprio Pluto. O nome Teoclímeno também lembra um pouco o apelido Klymenos, dado a Hades especialmente em associação a Deméter.

${ }^{69}$ Meltzer tem ideias semelhantes (1994, p. 38), enquanto Zuntz sublinha a ironia da ambivalência de Helena (1958, p. 223 e ss.).
} 
de Helena em favor de uma inteligência humana, de modo que a Helena de Troia seria filha de Zeus, enquanto a Helena do Egito reconheceria apenas Tíndaro como seu pai. No entanto, essa interpretação esquemática tem muito pouco apoio textual e se baseia mais no que o texto não diz do que no que diz.

Além do mais, o privilégio do não sofrimento citado por Wolff acima poderia ser atribuído à ascendência divina de Helena, caso se leiam os versos 1678-9, como querem Juffras (2003, p. 46) e Grégoire (1950, p. 119) ${ }^{70}$ :

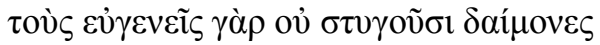

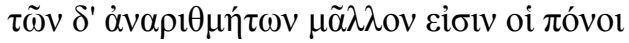

Pois as divindades não odeiam os bem-nascidos, e as penas são antes para as massas.

A revelação final da personagem acontece no momento do assassinato dos homens de Teoclímeno, durante a fuga de Helena e Menelau, uma cena que é comumente identificada pelos comentadores como uma pequena reencenação da guerra de Troia ${ }^{71}$. Postada na popa do barco que a levará junto com o marido e os companheiros de volta a Esparta, Helena exorta os gregos na matança dos bárbaros (vv. 1603-4):

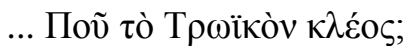

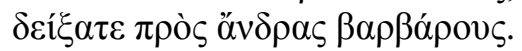

Onde está a glória de Troia? Mostrai a estes bárbaros!

Lutar por Helena, no fim das contas, não se mostra desvantajoso. Como já acontece na Odisseia, em que os Campos Elísios são o destino de Menelau (IV.561569), a tragédia de Eurípides também garante ao herói um afortunado post mortem, na Ilha dos Bem-Aventurados (vv. 1676-7). A experiência egípcia também funciona como uma espécie de lição, que ensina a Menelau que as guerras mais encarnadas são justamente aquelas que se lutam por um fantasma ${ }^{72}$.

\footnotetext{
${ }^{70} \mathrm{Na}$ minha tradução, sigo a leitura de Diggle, que põe o texto entre cruzes: "Pois as divindades não odeiam os bem-nascidos, mas eles $\dagger$ aguentam mais penúrias $†$ do que a multidão dos inumeráveis." ${ }^{71}$ e.g. Juffras (2003, p. 46).

${ }^{72}$ Loraux, 1989, p. 247.
} 


\section{4 À GUISA DE CONCLUSÃO}

Este trabalho quis compreender a Helena de Eurípides a partir de representações anteriores do mito. Como já notado diversas vezes, o mito de Helena explora tensões sobre a alteridade fundamental da mulher e sobre o feminino no contexto de troca entre famílias próprio ao casamento. A principal conclusão a que chegamos é que o drama de Eurípides não apenas mantém a ambiguidade tradicional da personagem, como a realça, valorizando sua complexidade.

Sendo isenta do crime de adultério - por ação dos deuses, é verdade -, a Helena de Eurípides extrapola o comportamento heroico padrão na medida em que não apenas reage com dignidade às intempéries da sorte e da divindade, como também assume uma postura mais ativa e manipula as próprias circunstâncias da vida.

Ainda que fiel e constante à Menelau, em suas vestes brancas e seus cantos lamentosos, essa Helena egípcia, diante de um oponente masculino, mostra-se sedutora, ardilosa e capaz do fingimento mais verossímil.

Como musa secundária, Helena fabrica falsas narrativas com aparência de

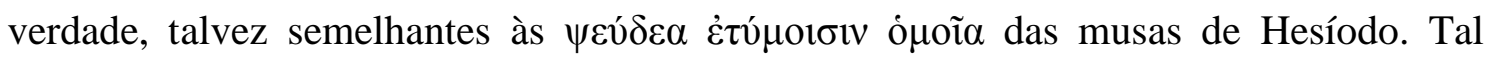
habilidade evoca um possível aspecto divino de Helena, identificável na provável origem divina da personagem e, no drama em questão, no prenúncio de seu futuro como deusa. Ao mesmo tempo, Helena age como dramaturga, diretora e atriz, quando põe em cena seu próprio drama.

Não ignoramos que uma certa espécie de domesticação de Helena acontece em Eurípides, uma vez que todas as suas habilidades perigosas são direcionadas a favor dos interesses de seu esposo Menelau. Mas vendo Helena fingir o próprio luto, Menelau ainda deveria bem se lembrar de sua esposa em Troia, imitando as vozes de outras esposas gregas ao redor do cavalo de madeira. 
Parte II - Tradução 


\section{PREFÁCIO À TRADUÇÃO}

O texto de base para esta tradução é o da coleção Oxford Classical Texts, editado por James Diggle (1994). As outras edições, traduções e comentários consultados foram: Allan (2008), Burian (2007), Kovacs (2002; 2003), Amiech (2011), Dale (1967), Grégoire (1950) e José Ribeiro Ferreira (in: EURÍPEDES, 2009).

Na tentativa de conferir algum grau de formalização à tradução em português, considerando a estrutura altamente formalizada do drama grego, optei por uma tradução em versos livres, ao invés de em prosa. Em favor de uma maior fluidez de ritmo na língua-meta, decidi, por vezes, não manter a divisão original de versos da língua-fonte. Por esta razão, a indicação dos versos à direita da tradução se refere sempre ao texto grego.

Para marcar a diferença entre partes cantadas e partes faladas, optei por usar itálico para distinguir as partes cantadas e também imprimi estrofes e antístrofes alinhadas à esquerda e à direita como vaga lembrança do movimento do coro.

A primeira estrofe do párodo (vv. 169-190) foi a única passagem em que me distanciei consideravelmente do texto de Diggle, baseada nas extensas discussões dos comentadores. Por essa razão, imprimo a seguir o texto traduzido, com aparato mínimo e explicações de leitura.

167 170

\author{
$\pi \tau \varepsilon \rho о \varphi o ́ \rho 01 ~ v \varepsilon \alpha ́ v 1 \delta \varepsilon \varsigma$,

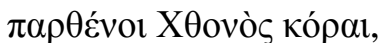

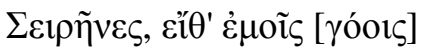

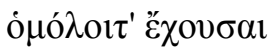

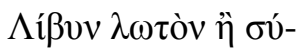

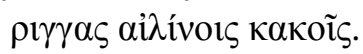

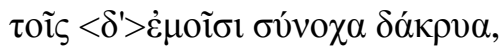

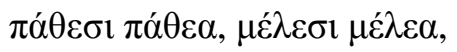 \\ $\mu о v \sigma \varepsilon \tilde{\alpha} \alpha \rho \emptyset \eta \eta \dot{\mu} \mu \alpha-$

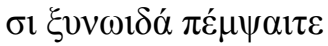

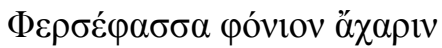

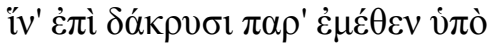

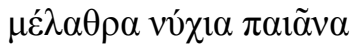

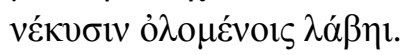

\author{
Donzelas aladas, \\ virgens filhas da Terra, \\ Sereias: com oboé líbio \\ ou flautas, juntai-vos a mim \\ em meus dolorosos males. \\ E enviai, cantoras, lágrimas \\ em harmonia aos meus trenos, \\ mágoas como as minhas mágoas, \\ cantos como os meus cantos, \\ para que, lá embaixo, \\ em sua noturna morada, \\ de mim receba Perséfone, \\ além das minhas lágrimas, \\ um peã aos mortos - sangrento e sem graça.
}

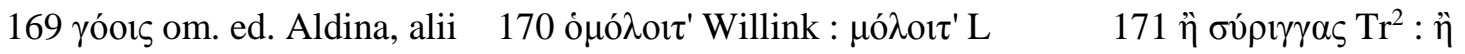

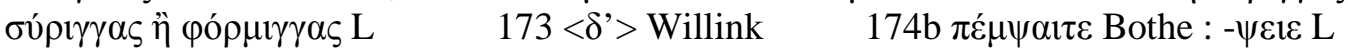

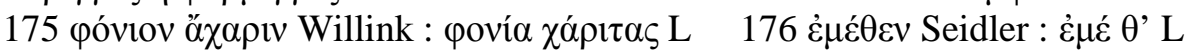




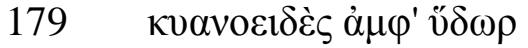

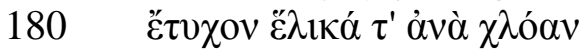

poívikas $\dot{\alpha} \lambda i ́ \omega 1$

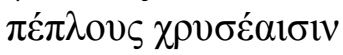

$\left\langle\tau^{\prime} \dot{\varepsilon} v>\alpha \hat{\gamma} \gamma \alpha \tilde{\sigma} \sigma<1>\theta \alpha ́ \lambda \pi 0 v-\right.$

183

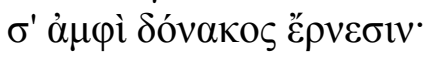

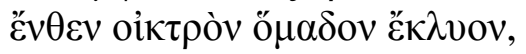

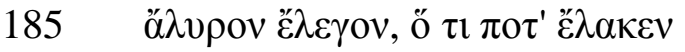

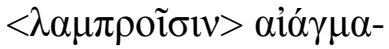

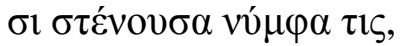

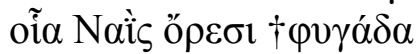

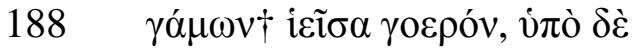

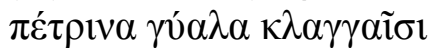

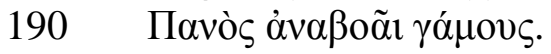

Perto d'água azul-marinha

e da relva espiralada, estava eu secando os fenícios peplos sobre brotos de junco, ao sol de dourados raios: de lá ouvi triste ruído, canção imprópria à lira, o que, uma vez, certa ninfa gritou gemendo em altos ais, tal como uma Náiade que nas montanhas fugindo, deixa escapar um lamento e, sob rochoso côncavo, com clamores chora sua união a Pã.

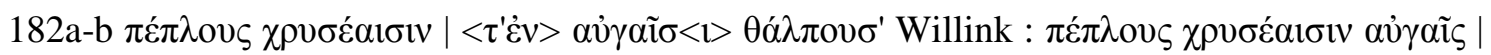

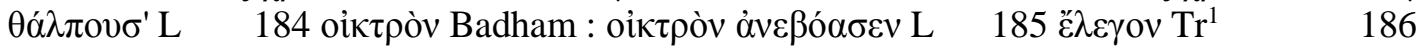

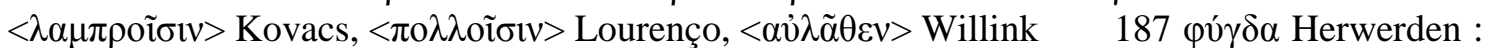

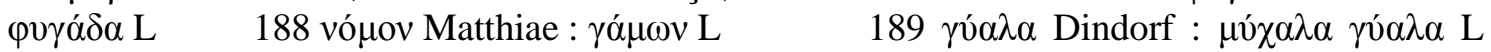

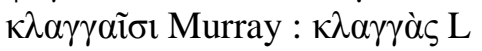

$\mathrm{Na}$ estrofe, minha tradução segue, em linhas gerais, as interpretações de Kovacs (2002) e Allan (2008), ambas amplamente baseadas nas leituras de Willink (1990). Desse modo, leio ' $\mu$ ov $\sigma \varepsilon \tilde{\alpha} \alpha$ ' como um nominativo plural em aposição, significando, por metonímia, "cantoras". Considero pertinente a crítica de Willink a essa interpretação de

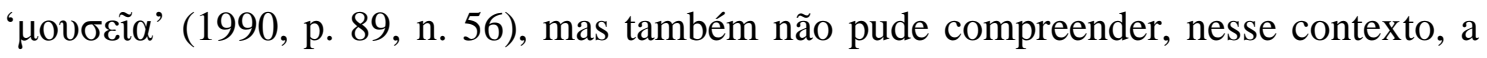
palavra no seu sentido básico de "salão musical" 73 . Pela fluidez da tradução, modifiquei

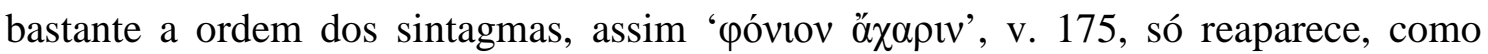
“sangrento e sem graça", no v. 178 da tradução.

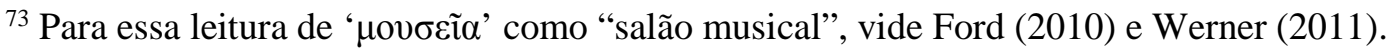




\section{TRADUÇÃO}

(Helena está sozinha, junto ao túmulo de Proteu e diante da skené que representa o palácio.)

\section{HELENA:}

Do Nilo são estas correntes de belas virgens

que, em lugar da chuva de Zeus, molham a terra,

o torrão egípcio, quando derretida a branca neve.

Proteu, enquanto vivia, era o rei dessa terra

[habitando a ilha de Faros, mas senhor de todo o Egito].

Com uma das virgens do mar ele casou-se,

Psamateia, depois que essa deixara o leito de Éaco;

e, nesse palácio, ela deu à luz dois filhos:

o varão Teoclímeno, [assim chamado porque sempre

temente aos deuses], e a nobre virgem Eidó,

ornamento da mãe quando pequenina,

mas que, depois que alcançou a idade de casar,

foi chamada Teônoe, pois sabia todas as coisas divinas,

as que são e as que serão, honra essa herdada de Nereu, seu ancestral.

Quanto a mim, a minha terra pátria é a não inglória Esparta,

e Tíndaro é meu pai. Há decerto uma história,

segundo a qual, Zeus voou para minha mãe,

Leda, na forma de um cisne que fugia da perseguição de uma águia,

e assim logrou um leito enganoso - se é mesmo certa uma história tal.

Helena é meu nome, e os males que sofri hei de vos contar.

Três deusas foram, pela causa da beleza,

a um vale do monte Ida, em busca de Alexandre,

Hera, Cípris e a virgem filha de Zeus,

querendo elas decidir um concurso de formosura.

E tendo oferecido a minha beleza - se é mesmo belo o infortunado -

para que Alexandre desposasse, Cípris

venceu. Então Páris do monte Ida deixou seu rebanho

e foi à Esparta para me tomar como esposa. 
Mas Hera, inconformada por não ter vencido as outras deusas,

inflou de vento meu tálamo com Alexandre:

não foi a mim que ela entregou ao filho do rei Príamo,

mas um fantasma vivente, que ela forjou do céu à minha semelhança.

E ele imagina que me tem - imagem ${ }^{74}$ vã -, quando não tem.

Também os planos de Zeus, por seu lado, a esses outros males juntaram:

guerra ele levou aos gregos e aos infortunados frígios

para aliviar a mãe terra da enorme multidão de mortais

e também para que se conhecesse o mais poderoso da Hélade.

E para a luta contra os frígios, não eu, mas o meu nome

foi posto como prêmio de guerra aos gregos.

Pelas dobras do éter, Hermes me levou escondida em uma nuvem,

(porque não fora Zeus negligente comigo) e me estabeleceu nesta casa de Proteu,

que ele julgara o mais virtuoso dentre todos os mortais,

a fim de que eu mantivesse meu leito incorrupto para Menelau.

E aqui estou eu, mas o meu combalido esposo reuniu um exército

e marchou contra as torres de Troia para me apanhar de volta.

Muitas almas, por minha causa, às margens do Escamandro,

pereceram. E eu, que tudo isso aturei,

sou amaldiçoada e julgada, como se tivesse abandonado meu esposo

e assim causado aos gregos uma guerra enorme.

Por que, então, ainda vivo? Do deus Hermes ouvi a palavra

de que ainda habitarei o solo glorioso de Esparta com o meu marido,

quando ele souber que a Ílion nunca fui

- isso contanto que eu não tenha servido o leito de nenhum outro.

De fato, enquanto via a luz do sol

Proteu, estive livre de casamentos; mas, depois que foi coberto

pela escuridão da terra, o filho do falecido

me persegue para se casar comigo. E, em honra ao marido de antanho,

estou ajoelhada neste mausoléu de Proteu,

como suplicante, a fim de que isso preserve o meu leito para Menelau.

Pois, se pela Hélade carrego um nome infame,

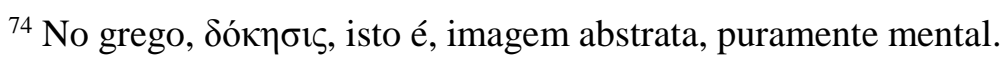


que, pelo menos, meu corpo aqui não incorra em vergonha.

(Entra Teucro pelo eisodos que leva à costa.)

\section{TEUCRO:}

Quem será o senhor deste palácio fortificado?

Com efeito, do próprio Pluto é digna uma morada assim,

tão régias as suas muralhas e tão bem acimalhadas as suas câmaras.

Eia!

Ó deuses, que visão é essa que descubro?! A imagem mortífera

da mulher mais odiosa, ela que arruinou a mim

e a todos os aqueus! Que os deuses te repudiem

por carregares uma imagem assim tão parecida com a de Helena!

Se meus pés não estivessem em terra estrangeira, com certeza morrerias por essas bem-miradas flechas, como recompensa por tua semelhança à filha de Zeus.

HE. Ó miserável, quem quer que sejas tu, por que te viras contra mim

e me odeias pelos infortúnios causados por aquela outra?

TE. Errei. Cedi à raiva mais do que deveria.

É que toda a Grécia odeia a filha de Zeus.

Desculpa-me pelo que disse, senhora.

HE. Quem és tu? De que terra vieste até aqui?

TE. Sou um dos aqueus, senhora, um dos infelizes.

HE. Pois então não é de se espantar que odeies tanto Helena.

[Mas quem és e de onde vens? Filho de quem eu devo te chamar?

TE. Meu nome é Teucro, o pai que me gerou foi

Télamon, e Salamina a pátria que me nutriu.

HE. O que então te trouxe aos campos do Nilo?] 
TE. Sou um exilado, fui banido da terra pátria.

HE. Coitado de ti! Mas quem te expulsa da pátria?

TE. Télamon, que me gerou. Que pessoa mais querida poderia haver?

HE. Mas por quê? Um ato assim envolve desgraça.

TE. Ájax, meu irmão, me destruiu quando morreu em Troia.

HE. Mas como? Não foste tu a tirar-lhe a vida com tua espada, foste?!

TE. Atirando-se a sobre sua própria espada, morreu.

HE. Estava louco? Que homem são ousaria fazer isso?

TE. Conheces um certo Aquiles, filho de Peleu?

HE. Sim. Ele foi pretendente de Helena, segundo ouvi dizer.

TE. Quando morreu, deixou uma disputa por suas armas entre os aliados.

HE. E como é que isso resultou em desgraça a Ájax?

TE. Depois que um outro ficou com as armas, matou-se.

HE. E tu então sofres pelos males dele?

TE. Sim, porque não morri com ele.

HE. Então foste, estrangeiro, à famosa cidade de Troia?

TE. Ajudei a saqueá-la; em troca, me destruí. 
HE. Então já foi tomada e subjugada pelo fogo?

TE. De modo que não há vestígio evidente de suas muralhas.

HE. Pobre Helena! Por sua causa, pereceram os frígios.

TE. Sim, e os aqueus também; grandes males ela engendrou.

HE. E há quanto tempo a cidade foi devastada?

TE. Quase sete círculos de anos dobrados.

HE. E por mais quanto tempo permaneceram em Troia?

TE. Muitas luas, passaram-se dez anos completos.

HE. E a mulher espartana vós também capturastes?

TE. Menelau arrastou-a pelos cabelos.

HE. Viste tu a infeliz, ou falas de ouvir?

TE. Como te vejo agora com meus próprios olhos, nada menos.

HE. Mas observa se não tivestes uma imagem vinda dos deuses.

TE. Recorda-me algum outro assunto - chega dessa mulher!

[HE. Então imaginas que essa imagem era indubitável?

TE. Porque a vi com meus próprios olhos, e a mente ainda a vê.]

HE. E já está em casa com o marido Menelau?

TE. Certamente não em Argos, e nem às margens do Eurotas. 
HE. Ai ai! Um mal noticiaste... para aqueles de quem falas.

TE. O que se diz é que ele e a mulher estão desaparecidos.

HE. O caminho não era o mesmo para todos os argivos?

TE. Era, mas uma tempestade os dispersou em caminhos diferentes.

HE. Em que parte do vasto mar estavam?

TE. Estavam no meio da travessia do Mar Egeu.

HE. Desde então ninguém soube de Menelau ter chegado?

TE. Ninguém. Pela Hélade, diz-se que ele morreu.

HE. Estou perdida! E a filha de Téstio ainda é viva?

TE. Falas de Leda? Partiu, está morta.

HE. De certo que não foi a fama vergonhosa de Helena que a destruiu?

TE. É o que dizem: morreu apertando com um laço o nobre pescoço.

HE. E os tindáridas ainda vivem, ou já não existem esses jovens?

TE. Morreram e não morreram, há duas versões.

HE. Qual a melhor? Ó infeliz de mim!

TE. Foram transformados em astros, dizem que são deuses.

HE. Belamente contaste isso, e qual a outra versão? 
TE. Que eles cortaram suas próprias gargantas por causa da irmã.

Mas chega de histórias. Não quero gemer duas vezes.

Já que vim a esta morada real,

querendo ver a profetisa Teônoe,

sê minha anfitriã, para que eu consiga os oráculos

que me digam como colocar minha vela em vento favorável

em direção à terra marítima de Cípris, onde Apolo me profetizou

que eu moraria, dando-lhe o nome de ilha de Salamina,

em honra da minha outra pátria.

HE. A própria viagem, ó estrangeiro, revelá-lo-á. Mas agora foge, deixa esta terra, antes que te veja o filho de Proteu,

que governa esta terra: ele está ausente,

confiado em seus cães para a matança de animais selvagens.

Ele assassina qualquer estrangeiro grego que lhe apareça.

O porquê disso não procure saber.

Eu mesma não conto - pois em que te ajudaria?

TE. Falaste bem, mulher, que os deuses

te deem boas recompensas em troca.

Ainda que tenhas o corpo semelhante ao de Helena, não tens semelhante coração, mas um bem diferente!

Que ela morra horrivelmente e que nunca às margens do Eurotas chegue, mas que tu, mulher, tenhas boa sorte sempre.

(Sai Teucro.)

HE.

Oh! Enquanto começo um grande clamor pelas minhas grandes dores, com que choro devo concorrer ou a que musa devo me aproximar?

[Com lágrimas, com trenos, ou com lutos? Ai ai!] ${ }^{75}$

${ }^{75}$ del. Willink 
Donzelas aladas,

virgens filhas da Terra,

Sereias: com oboé líbio

ou flautas, juntai-vos a mim

em meus dolorosos males.

E enviai, cantoras, lágrimas

em harmonia aos meus trenos,

mágoas como as minhas mágoas,

cantos como os meus cantos,

para que, lá embaixo,

em sua noturna morada,

de mim receba Perséfone,

além das minhas lágrimas,

um peã aos mortos - sangrento e sem graça.

180

\section{CORO:}

185

Perto d'água azul-marinha

e da relva espiralada,

estava eu secando os fenícios

peplos sobre brotos de junco,

ao sol de dourados raios:

de lá ouvi lamentável ruído,

185

canção imprópria à lira,

o que, uma vez, certa ninfa

gritou gemendo em altos

ais, tal como uma Náiade

que nas montanhas fugindo,

deixa escapar um lamento

e, sob rochoso côncavo,

190

com clamores chora sua união a Pã.

HE: Ó espólio de bárbaro remo,

filhas da terra grega, 
um dos nautas aqueus

passou, passou por aqui me trazendo lágrimas sobre lágrimas.

Dos escombros de Ílion

cuida o fogo destruidor,

por causa de mim, assassina de muitos,

por causa do meu nome, de muitos pesares.

Leda, enforcando-se,

apoderou-se da morte,

em razão da aflição pela minha desonra.

E o meu marido, que pelo mar

muito errou, está morto e acabado.

Castor e seu irmão,

gêmeo esplendor da nação,

sumiram, sumiram! Deixaram

a planície ressoante de cascos

e os ginásios do juncoso Eurotas,

onde treinam os mancebos.

CO: Ai ai! É muito penosa divindade

o teu destino, mulher!

Uma vida que não é vida

tomou, tomou a ti, quando Zeus da mãe te gerou,

reluzente através dos éter,

215

com asa branco-nívea.

Oh sim! que outro mal carece aos teus males?

Que coisa durante a vida não aturaste?

A mãe acabou-se.

220

Os gêmeos de Zeus,

estimada progênie, já não mais prosperam,

e a terra pátria tu já não vês.

Um boato corre pelas cidades

de que tu, soberana,

225

a um leito bárbaro passou.

E seu 'sposo no mar crispado 
deixou a vida; e não mais alegrarás tu

a residência pátria, nem Atena

que habita brônzeo templo.

HE. Ai ai! Qual dos frígios

ou dos gregos cortou

da terra lacrimoso pinheiro para Ílion?

Dele moldou ruinoso

barco o priamida

e navegou com bárbaro remo

rumo à minha casa

[rumo à mais infortunada

formosura, para que adquirisse minhas núpcias]

e com ele a enganadora e assassina Cípris

levando a morte aos dânaos [e priamidas].

Ó infeliz circunstância!

E ela, a que senta em dourado trono,

amante venerável de Zeus,

Hera, enviou o de rápidos pés,

o filho de Maia,

e, enquanto eu colhia em minhas vestes

frescas pétalas de rosas para Atena de brônzeo templo,

ele me raptou e carregou através do éter

até essa terra não abençoada e me fez

o motivo de dissídio, dissídio infeliz

entre troianos e gregos.

Meu nome junto às correntes do Simoente

falsa fama carrega.

CO. Sofres, eu sei. Mas é conveniente suportar as privações da vida

o mais levemente possível.

HE. Mulheres amigas, a que destino eu fui atrelada?

Então a que me gerou pariu-me como um portento aos homens? 
[Com efeito, nenhuma outra mulher, grega ou bárbara,

colocou branco conceptáculo de passarinho,

como naquele em que - dizem - Leda de Zeus me gerou.] ${ }^{76}$

Sim, portentosa é a minha vida e tudo ao meu respeito,

em parte, por causa de Hera, em parte, pela minha beleza.

Ah, se eu pudesse ser apagada, como uma pintura,

e tomasse outra forma, uma mais feia, em lugar dessa bonita,

e as desditas de que padeço agora

os gregos tivessem esquecido, e preservassem

as felicidades como agora preservam os meus infortúnios.

Alguém que perscrute uma única eventualidade

e seja afligido pelos deuses, sofre, mas pode suportar,

mas eu estou afundada em múltiplos infortúnios.

Primeiro, sem ser injusta, estou desonrada,

e este é um mal maior do que a verdade:

o de suportar males que não lhe pertencem.

Depois os deuses me transferiram da terra pátria

para os bárbaros, e, despojada de amigos,

escrava me tornei, apesar de ter nascido livre,

pois entre os bárbaros todos são escravos, exceto um.

A âncora que sustentava o meu fadário era uma só,

o marido que um dia viria e me libertaria dos meus males;

mas, já que ele está morto, não há mais.

A mãe está acabada, e eu sou sua assassina.

Decerto injustamente, mas o que é injusto me pertence.

O ornamento da casa, minha filha,

sem marido e grisalha, segue virgem.

Os Dióscuros, assim chamados porque filhos de Zeus,

não mais existem. E mesmo padecendo de todas as desgraças,

76 Os editores modernos se dividem quanto à autenticidade dos versos 257-9. A deletio, originalmente proposta por Wieland, é aceita por Kannicht e Diggle. Mas Allan, Burian e

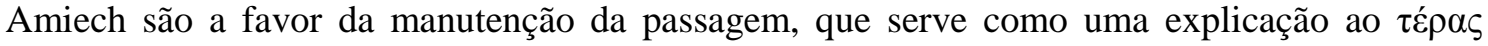
'portento' do v. 256. Há ainda uma proposta, preferida por Kovacs, de manter os versos 257-9, mas transpor o v. 256 para depois do bloco, o que faz do v. 260 uma resposta direta à pergunta do v. 256. 
estou morta apenas quanto às circunstâncias, mas não na realidade.

[E a pior parte é essa: mesmo que chegasse à terra pátria, seria barrada nos portões, pois pensariam que eu fosse a Helena que foi a Troia com Menelau.

É que se o marido estivesse vivo, nós nos reconheceríamos

pelos sinais conhecidos apenas por nós.

Mas agora isso não é mais possível, e ele não sobreviverá de jeito algum.]

Então, por que ainda vivo? Que sorte me resta?

Preferir o casamento às adversidades

e viver com um homem bárbaro, sentada à sua opulenta mesa?

Mas quando um marido acre une-se a uma mulher,

o seu próprio corpo a ela se torna acre também.

[Melhor morrer. Mas como então morrer com nobreza?

Enforcar-se é vergonhoso,

coisa indigna até mesmo aos escravos.

Morrer pela espada é nobre e belo,

mas curto é o ponto vital que desprende a vida.]

Atingi assim o topo dos meus males:

enquanto outras mulheres, por causa da beleza, foram bem-aventuradas, a mim a mesma coisa destruiu.

CO. Helena, quem quer que seja esse estrangeiro que aqui veio, não tomes como verdade tudo o que disse ele.

HE. Mas ele disse claramente que meu marido está morto.

CO. Muito do que se diz claramente não passa de mentira.

HE. E, pelo contrário, também muito é verdade.

CO. Falas assim porque estás mais para infortúnios do que para o bem.

HE. Sim, porque o medo me domina e me guia para o que mais temo. 
CO. Em quão boa graça estás dos que vivem na casa?

HE. Todos são amigos, com exceção daquele que caça minhas bodas.

CO. Aí vai o que tens que fazer: deixa esse refúgio do mausoléu...

HE. Mas que discurso ou conselho é esse?

CO. ... e vai à casa e àquela que tudo sabe,

a filha da nereida do mar, Teônoe,

pergunta-lhe do teu marido, se ainda vive,

ou se deixou a luz do dia; e, então, sabendo de fato,

alegra-te ou lamenta-te de acordo com a tua sorte.

Mas antes de ter ciência certa das coisas, que vantagem há

em sofrer? Faz o que digo!

[Abandona este túmulo e encontra a donzela

de quem saberás tudo. Já que a tens em casa

para dizer-te toda a verdade, por que procurar adiante?]

E eu também quero entrar contigo na casa

para pedir junto a ti pelos oráculos da virgem,

afinal, as mulheres devem se unir na necessidade.

HE. Amigas, eu aceito vossos conselhos

entrai, entrai na casa,

para que lá dentro escuteis

os desafios que me esperam.

CO. Vou de boa vontade, não precisas me chamar duas vezes.

HE. Ó dia infeliz!

Que história de lágrimas

ouvirei, miserável que sou?

CO. Não sejas profeta de aflições, 
nem antecipes lamentos, amiga.

HE. E o que aturou meu marido infeliz?

Acaso vê a luz do dia,

a quadriga do sol

e os caminhos dos astros,

ou, entre os mortos, debaixo da terra,

suporta a sorte duradoura?

CO. O que quer que ofuturo traga,

cuida que seja o melhor.

HE. Eu invoco a ti, eu juro a ti,

Eurotas verde, de juncos aquáticos,

que, se é verdade o rumor

de que está morto o esposo

$\dagger$ como não compreender isso?†,

enforcamento fatal

pelo pescoço alcançarei,

ou a espada de sangrenta

matança enterrarei fundo

dentro da carne, como prova de força suicida,

oferenda sacrificial às três deusas emparelhadas

e ao priamida que, um dia, na caverna oca,

sentou-se com seu rebanho.

CO. Que se afastem esses males!

Que seja boa a tua sorte!

HE. Oh, Troia infeliz! ${ }^{77}$

Por causa de feitos não-feitos, sofreste misérias, pereceste.

${ }^{77}$ Durante essa última estrofe cantada apenas por Helena, presume-se que o coro saísse em silêncio, talvez ainda dançando. Sobre a mise-en-scène desse trecho, vide Taplin, 1977, p. 376. 
A minha dádiva de Afrodite engendrou

copioso sangue, copiosas lágrimas,

$\dagger$ acarretou dores sobre dores, lágrimas sobres lágrimas, sofrimentos $\dagger$

mães perderam seus filhos,

e as virgens, irmãs dos cadáveres,

cortaram seus cabelos, junto ao frígio

rio Escamandro.

E longos ais e gritos de dor

a Grécia lançou,

pôs as mãos na cabeça

e banhou as delicadas faces

com sangrentos golpes de unhas.

Ó abençoada donzela da Arcádia,

Calisto, que deixou o leito de Zeus

como animal de quatro patas,

- como foi melhor que a minha a tua sina!

Na forma de uma fera de patas cabeludas,

[de olhar feroz, a figura de uma leoa]

alienaste a carga dolorosa.

E também tu, titanida filha de Mérope,

que, por causa da tua beleza, foste expulsa do coro de Ártemis,

na forma de uma corça de chifres de ouro.

Mas a minha figura arrasou, arrasou a cidade dardânia

e os aqueus arrasados estão.

(Helena e o coro saem. Entra Menelau pelo eisodos que leva à costa.)

MENELAU.

Ó Pélope, que, uma vez, em Pisa, bravamente

disputaste a corrida de quadrigas com Enomeu, ah! se [naquele dia em que, persuadido, 
serviste banquete aos deuses] tivesses deixado a vida, ${ }^{78}$

antes de haver jamais gerado meu pai Atreu!

De seu tálamo com Aérope

gerou Agamêmnon e a mim, Menelau - célebre parelha.

Com efeito, penso - e não falo para me gabar -

ter sido a maior das expedições a que eu levei a Troia por barco,

comandando não como tirano, e nem liderando as tropas à força,

mas conduzindo os jovens gregos com consentimento deles.

É possível contar os que não mais existem,

tanto quanto os que felizes escaparam ao mar,

levando de volta para casa os nomes dos que pereceram.

Quanto a mim, pelas ondas do salgado mar brilhante,

perambulo, paciente, desde o tempo em que saqueei as torres de Troia.

Ainda que anseie por alcançar a terra pátria,

aos deuses não sou digno dessa sorte.

Naveguei por todos os atracadouros desertos

e inóspitos da Líbia. E toda vez que estivesse perto de casa,

mais uma vez, um vento me afastava, e nunca um sopro favorável

atingia minha vela para me fazer chegar a pátria.

E agora, como infeliz náufrago, depois de perder companheiros,

chego a esta terra. A nau contra as pedras

partiu-se em mil pedaços.

De suas peças habilidosamente ajustadas, sobrou só a quilha,

sobre a qual consegui me salvar a duras penas,

com Helena, que trouxe arrastada de Troia.

Não sei o nome deste povo e desta terra,

porque tive vergonha de me aproximar da multidão

[para que não reparassem nos meus andrajos]

e por pudor escondi meus infortúnios. Quando um homem

nobre sofre agruras, cai num estado a que não está acostumado,

${ }^{78}$ Porque o trecho correspondente aos versos 388 b-389a se encontra muito corrompido e com interpolações, traduzo seu conteúdo apenas parcialmente. Não satisfeita com as propostas de

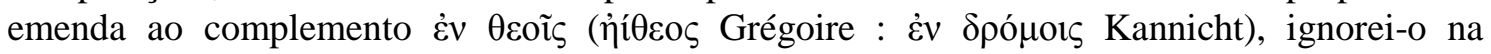
tradução. 
e sofre mais do que aquele que já é infeliz faz tempo.

Mas a necessidade me oprime: não há alimento

e nem roupas sobre a pele - o que dá para inferir

dos destroços da nau que uso para me cobrir.

Dos peplos luxuosos e das vestes brilhantes de outrora

o mar se apoderou. Nos recônditos de uma caverna,

escondi a mulher que é causa de todos os meus males,

forcei os companheiros sobreviventes a vigiá-la e aqui estou.

Sozinho venho, procurando provisões para os companheiros,

se acaso conseguir encontrar alguma coisa.

Vi esta casa, de algum homem rico,

cercada por muros e veneráveis portões,

e me aproximei. De casas ricas há esperança de conseguir

alguma coisa para os meus marinheiros, mas os pobres,

ainda que eles quisessem, não teriam como ajudar.

Ei, sentinela! Por favor, sai de casa, vem aqui

e comunica ao interior as minhas aflições.

(Sai do palácio a anciã.)

\section{ANCIÃ:}

Quem está junto aos portões? Deixa essa casa!

E não fiques aí parado junto aos portões do pátio!

Não incomodes o soberano! Ou morrerás!

És grego, e gregos aqui não têm vez!

ME. Ó anciã, †falas muito bem essas palavras! $\uparrow^{79}$

Tudo bem, convenceste-me, mas larga de raiva!

AN. Vai embora! Estou incumbida disto, estrangeiro:

não deixar que nenhum dos gregos se aproxime da casa.

${ }^{79} \mathrm{O}$ texto está corrompido. Na leitura de Diggle, o tom é de ironia. 
ME. Ai! não levantes o punho, nem me empurres à força!

AN. Vou sim, porque tu não escutas nada do que digo! A culpa é tua!

ME. Comunica aos teus soberanos lá dentro que...

AN. Acre, eu acho, vai ser comunicar o teu recado.

ME. Aqui venho como um estrangeiro náufrago, espécie inviolável.

AN. Vai embora agora para outra casa que não seja esta!

ME. Não, eu vou entrar; e tu faz o que eu digo.

AN. Vê, tu és incômodo; e já, já serás expulso à força.

ME. Ai ai! As minhas célebres tropas, onde estão?

AN. Com certeza, tu foste alguém venerável em outro lugar, mas não aqui.

ME. Ó destino, que desonra imerecida eu sofro!

AN. Por que molhas as pálpebras de lágrimas? Aos olhos de quem és lamentável?

ME. Aos olhos da minha venturosa posição de outrora.

AN. Então vai embora e vai chorar aos teus amigos!

ME. Que terra é esta? De quem é esta morada real?

AN. Esta é a casa de Proteu, e a terra é o Egito.

ME. Egito? Ó infeliz! Até onde eu fui navegar! 
AN. Que há para censurar nas brilhantes águas do Nilo?

ME. Não censuro a ele, a minha sorte é que eu lamento.

AN. Muitos sofrem desgraças, tu não és o único.

ME. Então está em casa o rei de que me falaste?

AN. Este é o seu mausoléu, seu filho governa a terra.

ME. E onde estaria? Fora ou dentro de casa?

AN. Está fora, e é o mais hostil aos gregos.

ME. E qual a causa pela qual pago?

AN. Helena, a filha de Zeus, está nesta casa.

ME. Que dizes? Que história contaste? Dize-me de novo.

AN. A filha de Tíndaro, que um dia esteve em Esparta.

ME. Vinda de onde?! Que explicação tem isso?!

AN. Da terra lacedemônia veio para cá.

ME. Quando? Minha mulher foi roubada da caverna?

AN. Antes de os aqueus, ó estrangeiro, chegarem a Troia.

Mas vai para longe desta morada. Há uma mudança por aqui,

e a casa real está mexida.

Chegaste em momento nada oportuno. E se o soberano

te pegar, a morte será tua xênia.

Favorável sou a todos os gregos - as palavras acres 
que disse foram por medo do meu soberano.

(Volta para o palácio a anciã.)

ME.

O que penso? O que digo? Após os infortúnios

de antes, ouço sobre esse árduo presente

- se é mesmo certo que de Troia eu vim trazendo

a esposa raptada, e, na caverna, ela está guardada,

enquanto alguém de nome idêntico à minha

esposa, uma outra, vive neste palácio.

A anciã disse ainda que trata-se da filha de Zeus.

Mas será mesmo possível que haja um homem chamado Zeus,

aqui pelas margens do Nilo? Não, há apenas um, o que vive no céu.

E onde haverá na terra uma outra Esparta, além de lá

onde estão as correntes de belos juncos do Eurotas?

Será que pode haver dois homens chamados Tíndaro

e alguma terra homônima a Lacedemônia

ou a Troia? Não sei o que dizer.

É que parece que, pelo mundo, há muitos

que têm nomes idênticos, e o mesmo vale para as cidades

e também para as mulheres. Não há do que se admirar.

Não vou fugir da ameaça de uma serva.

Não há homem que seja de coração tão bárbaro

que, ouvindo meu nome, não me dê alimento.

[O fogo de Troia é famoso, assim como eu que o ateei,

Menelau, não desconhecido por toda a terra.

Esperarei o senhor da casa; ele me dá duas opções

de cautela: se for perverso, ficarei escondido

e voltarei para junto dos destroços do navio,

mas se apresentar algum sinal de gentileza,

pedirei pelo necessário às minhas atuais circunstâncias.]

Este é para mim o pior de todos os males:

sendo rei eu mesmo, ter que mendigar a outros tiranos 
pela subsistência; no entanto, é preciso.

Não é palavra minha, mas de algum sábio:

não há nada mais poderoso do que a terrível necessidade.

(Epipárodo.)

\section{CORO.}

Escutei da jovem profetisa

o que queria quando fui ao palácio do tirano:

que Menelau ainda não se perdeu pela escuridão

brilhante do Érebo e não está oculto pela terra,

mas ainda se consome ao longo das ondas salgadas,

sem alcançar porto da terra pátria,

miserável pela vida errante,

e de amigos privado,

atingindo terras de todo tipo com o remo marinho,

desde que deixou a terra de Troia.

(Helena entra seguindo o coro. Menelau ainda está em cena.)

\section{HELENA.}

E eu novamente volto ao meu assento neste túmulo, depois de ouvir de Teônoe palavras amigas.

[Ela realmente sabe de todas as coisas; e diz que vive

o meu marido, que está vivo e que vê a luz do dia!

Navegou incontáveis mares, vagando

pra cá e pra lá, não inexperiente em perambulações, mas virá quando chegar o fim de seus suplícios.

Uma coisa não disse: se, depois que vier, sobreviverá.

Eu me reservei de perguntá-lo abertamente,

alegre que fiquei, quando me disse que ele sobrevivera.

Mas disse que ele estaria em algum lugar perto daqui,

naufragado e soçobrado com alguns poucos companheiros. 
Ai de mim! Quando virás? Como estou ansiosa por que venhas!]

Eia! quem é este? Será que me preparam uma cilada

por determinação do sacrílego filho de Proteu?

E por que, qual rápida potra ou bacante tomada pelo deus,

não juntarei minha perna a este túmulo? Há algo de selvagem

na expressão deste que me persegue.

ME.

Tu que te apressas com enorme esforço

em direção à base do túmulo e às colunas onde se queimam as oferendas:

para! Por que foges? Assim que revelaste teu corpo,

deixaste-me perplexo e sem palavras.

HE.

Ai, mulheres, estou sendo ultrajada! Por este homem

sou impedida de alcançar o túmulo, e ele quer

me pegar para me dar ao tirano de quem evito o consórcio.

ME. Não sou ladrão, e nem servo de malvados.

HE. E ainda assim as roupas que tens ao redor do corpo são feias o suficiente para tanto.

ME. Abandona o medo e detém o pé ligeiro!

HE. Paro, mas só porque já toco o túmulo.

ME. Quem és? Que visão distingo em ti, mulher?

HE. E tu, quem és? A mesma pergunta vale para ti e para mim também.

ME. Nunca antes vi um corpo tão parecido.

HE. Ó deuses! pois divino é o reconhecer os amigos. 
< ME. És helênica ou mulher nativa? >

HE. Helênica. Mas a tua nacionalidade também quero saber.

ME. A Helena te vejo tão parecida, mulher!

HE. E eu te vejo a Menelau! Não sei o que dizer.

ME. E reconheceste corretamente o mais infeliz dos homens.

HE. Ó que longo tempo até que vieste para os braços de tua esposa!

ME. De que esposa? Não toques minhas roupas!

HE. Aquela que te deu Tíndaro, meu pai.

ME. Ó Hécate, que traz a luz, envia aparições benignas!

HE. Não é ministro noturno da deusa Enodia que vês em mim.

ME. Mas eu, com certeza, não sou um marido de duas esposas.

HE. Mas de que outra mulher és senhor?

ME. Daquela que está guardada na caverna, a que recuperamos dos frígios.

HE. Não há outra esposa tua que não seja eu!

ME. Estaria eu raciocinando bem, mas com os olhos doentes?!

HE. Pois, olhando para mim, não julgas ver tua mulher?

ME. O corpo é semelhante, mas não há certeza. 
HE. Observa com atenção; de que prova mais certa precisas?

ME. Pareces com ela; isso, com certeza, eu não posso negar.

HE. Quem mais pode te provar, além dos teus olhos?

ME. Aí está a enfermidade: outra mulher eu já tenho.

HE. Não fui eu a Troia, era um fantasma.

ME. E quem fabrica corpos que veem?

HE. O éter, é de lá que tens o leito feito pelos deuses.

ME. Formado por qual dos deuses? Inacreditável é o que me dizes.

HE. Hera o fez como um substituto, para que Páris não me tivesse.

ME. Como assim? Então estavas, ao mesmo tempo, aqui e em Troia.

HE. O nome pode estar em vários lugares, mas não o corpo.

ME. Deixa-me ir; cheguei aqui já com aflições suficientes.

HE. Então vais me deixar e levarás a esposa vã?

ME. Sim, e te desejo bem, porque és semelhante a Helena.

HE. Estou acabada! Mesmo tendo te encontrado, não terei marido.

ME. A magnitude dos sofrimentos de Troia me convencem, e não tu!

HE. Ai de mim! Haverá alguém mais infeliz do que eu?

Os mais amigos me deixaram, e eu não mais alcançarei a Hélade 
ou a minha terra pátria algum dia.

(Entra o servo de surpresa, enquanto Menelau já se prepara para sair.)

SERVO.

Menelau! Eis que te encontro, depois de muito procurar!

Vaguei por toda esta terra bárbara,

enviado pelos companheiros que foram deixados para trás.

ME. Mas o que há? Não fostes vós roubados por esses bárbaros, fostes?

600

SE. É admirável! Ainda que o seja menos de nome do que de fato.

ME. Diga, pois pela pressa, é algo de inopinado o que te traz.

SE. Digo que foi em vão que suportaste incontáveis penas.

ME. Lamentas por sofrimentos já antigos. E de novo, o que trazes?

SE. Partiu tua esposa, arrebatada, em segredo,

pelas dobras do éter. Está escondida no céu,

depois de ter deixado a reverenda caverna onde a guardávamos

com as seguintes palavras: "Ó infelizes frígios

e todos vós, aqueus: por mim, junto às margens do Escamandro,

dia após dia, vós seguíeis morrendo por força das maquinações de Hera,

imaginando que Páris possuía Helena, quando não possuía.

E eu, depois de ter permanecido pelo tempo que era necessário

e tendo garantido o que estava destinado a acontecer,

vou-me embora ao céu, meu genitor. A infeliz tindárida

ouviu injustas maledicências, de nada tendo culpa."

Ah! olá, filha de Leda! Então era aqui que estavas!

Contava eu como tu tinhas partido

pelos recônditos estrelares, porquanto não soubesse 
nada do corpo alado que tens. Não permito que tu zombes

de nós novamente, já que em Troia

já contribuíste com penas o suficiente para o teu marido e companheiros.

ME. Então é isto mesmo, a história dela acabou por ser verdadeira.

Ó dia tão esperado que te trouxe de volta aos meus braços!

HE. Ó mais amado dos homens, Menelau! ${ }^{80}$

Tão longo tempo demorou, mas agora o júbilo é completo!

Contente, recebo de volta meu esposo, amigas,

e estendo-lhe os braços amorosos ao seu redor

- depois de tantas auroras do sol reluzente!

ME. E eu te abraço também. Mas tenho tantas questões,

que agora nem sei por onde começar.

HE. Regozijo-me. De excitamento, meus cabelos ficam de pé, ${ }^{81}$

e lágrimas deixo cair.

Ao teu redor, meu marido, atiro os braços

para gozar deste prazer.

ME. Ó visão mais amada, não tenho do que me queixar.

$\dagger$ Possuo o fruto de Zeus e Leda. $\dagger$

HE. Sim, aquela que, sob as tochas, os moços de cavalos brancos, seus irmãos, proclamaram abençoada, abençoada!

\footnotetext{
${ }^{80}$ Nos versos 625-97, Helena e Menelau celebram o seu reconhecimento tardio em um dueto. Na primeira parte (625-59), que constitui o dueto propriamente dito, o casal se abraça comovido pelo reencontro. Na segunda parte (660-97), Menelau interroga Helena, em trímetros iâmbicos ou em partes líricas divididas, sobre detalhes de sua estadia egípcia, ao que sua esposa responde sempre cantando. Esse tipo de canção foi batizada por Willink (1989) de "monódia pontuada". ${ }^{81}$ Willink (1989) atribui toda a sequência dos versos 630-5 a Menelau e também reestrutura quase completamente os próximos versos da primeira parte do dueto, conhecida como o "enlace" (625-59). Além da busca pela simetria lírica, uma tese importante norteia a leitura de Willink: a de que a linguagem emotiva das partes cantadas também é adequada ao personagem masculino de Menelau. Para a tradução, atenho-me às leituras tradicionais da edição de Diggle.
} 
ME. Há tempos. Mas o deus que de casa e de mim

te levou à outra condição

agora te conduz a uma melhor sorte.

HE. Um feliz infortúnio reuniu a mim e a ti, ó esposo,

depois de longo tempo, mas ainda assim. Que eu bem aproveite desta sorte!

ME. Que realmente aproveite! Junto-me a ti na mesma prece.

É que quando se trata de um casal, um não é infeliz, sem que o outro também o seja.

HE. Amigas, amigas,

Não mais lamento ou sofro pelo passado.

Tenho meu marido, meu marido por quem esperei

e esperei, durante muitos anos, que voltasse de Troia.

ME. Sim, tens a mim, e eu tenho a ti.

Depois de padecer por incontáveis dias, enfim percebo a intervenção da deusa.

E de alegria minhas lágrimas têm mais prazer do que dor. ${ }^{82}$

HE. Que coisa digo? Quem dentre os mortais jamais esperou algo assim?

Inesperado te tenho junto ao peito.

ME. E eu a ti, que pensei teres ido à cidade do monte Ida

e às torres infelizes de Ílion.

Mas pelos deuses, como foste embora de nossa casa?

660

HE. Ai ai! Dolorosa é a causa que tu buscas!

Ai ai! Dolorosa é a história que procuras!

ME. Conta, pois é história que deve ser ouvida. São assim todas as dádivas divinas.

82 Para os versos 654-6, adoto as atribuições do manuscrito, ao invés das correções de Kretschmar adotados por Diggle: no OCT, 654-5 são dados a Helena, enquanto 656 fica com Menelau. A correção pretende atribuir todos os versos doquimíacos a Helena, mas a leitura do manuscrito tem a vantagem da simetria formal. Contra Diggle, Willink (1989, p. 58-9), Burian (2007, p. 232), Allan (2008, p.223) e Kovacs (2002, p. 84) preferem a leitura adotada aqui. 
HE. Uma história tal eu abomino,

uma história tal, como a que revelarei agora.

ME. Mesmo assim, conta. É agradável ouvir sobre males passados.

665

HE. Não foi para jovem leito de um bárbaro

que voei levada pelo rápido remo, nem foi o alado desejo

a me guiar para casamento injusto...

ME. Mas então que deus ou destino te privou de tua pátria?

HE. O filho de Zeus, de Zeus e Maia, ó esposo,

foi quem me levou ao Nilo.

ME. É de se admirar! Enviado por quem? Mas que história espantosa!

HE. Choro e encharco as pálpebras de lágrimas.

A esposa de Zeus foi quem me arruinou.

ME. Hera? Mas por que razão ela nos desejaria mal?

HE. Ai de mim! Foi por causa daqueles banhos e fontes

onde as deuses lavaram sua beleza,

quando foram ao julgamento.

ME. $\dagger$ E por que o julgamento deixou Hera com tanto rancor de ti? $\dagger^{83}$

HE. Para que ela roubasse Páris...

ME. Como? Fala!

HE. ... para quem Cípris tinha me destinado.

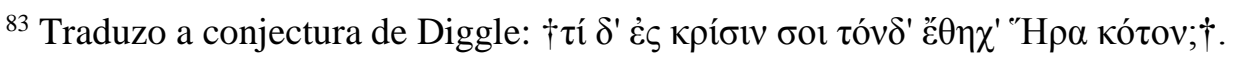


ME. Ó infeliz!

HE. Infeliz, infeliz mesmo! Trouxe-me ela ao Egito.

ME. Então Hera deu-lhe um fantasma em teu lugar, se te dou ouvidos.

HE. E em casa que dores, que dores eram as tuas, ó mãe!

Ai de mim!

ME. Que dizes?

685

HE. Não existe mais minha mãe! Deu um laço em volta do pescoço por vergonha do meu casamento impróprio.

ME. Ai de mim! E da nossa filha Hermione há alguma notícia?

HE. Sem esposo e sem filhos, ó marido,

ela lamenta <o meu> casamento que não é casamento... ${ }^{84}$

690

ME. Ó Páris, ao extremo pilhaste a minha casa!

HE. Ação que destruiu a ti e também a incontáveis

dânaos armados de bronze.

E longe da minha cidade e de ti, o deus me lançou,

desgraçada e execrada,

quando deixei, sem nunca ter deixado,

a tua casa e teu leito por uma vergonhosa união.

CO. Se, também no futuro, obtiverdes boa sorte, isso será suficiente para compensar o passado.

SE. Menelau, comigo também partilha deste prazer,

o qual eu mesmo percebo, mas não entendo perfeitamente.

${ }^{84}$ Traduzo $\ddot{\alpha} \gamma \alpha \mu o v<\dot{\varepsilon} \mu o ́ v>$ de Hermann em lugar da leitura transmitida ö $\gamma \alpha \mu o v \dagger \alpha i \sigma \chi v ́ v \alpha \dagger$. 
ME. Mas então, velho, participa também de nossa conversa.

SE. Não foi esta mulher a autora de nossos trabalhos em Ílion?

ME. Não esta: pelos deuses nós éramos enganados,

[tendo em mãos uma imagem ruinosa de nuvem.]

SE. [Que dizes?]

Então foi por uma nuvem, em vão, que suportamos tantas penas?

ME. Façanha de Hera e da disputa entre as três deusas.

SE. O quê, então?! Esta aqui que é realmente a tua esposa?

ME. Esta sim; quanto a isso, confia nas minhas palavras.

SE. Ó filha! Quão variada e indecifrável

é a divindade! Como desvia a tudo totalmente

[arrastando-o para lá e para cá! Um homem pena,

enquanto um outro que nunca penou depois morre horrivelmente,

nada de estável jamais tendo em sua sorte.

Tu e teu esposo tiveram vosso quinhão de males,

tu pela tua reputação e ele por sua prontidão para a lança.

Por todo o seu empenho, enquanto empenhou-se, nada obteve,

mas agora os bens lhe chegam por si mesmos e são os mais afortunados.]

Então não envergonhaste teu velho pai e os Dióscuros

e nem fizeste o que dizem.

Revivo agora mais uma vez a tua canção de casamento

e me lembro das tochas que eu carregava,

enquanto corria junto aos teus quatro cavalos atrelados. E tu, na carruagem,

com este aqui deixava, como noiva, a casa abençoada.

É que é mau aquele que não respeita os assuntos de seu senhor

e não se alegra com ele, nem se agonia com seus males.

[E eu, mesmo que tenha nascido como servo, 
que seja contado entre os escravos nobres, porquanto não tendo nome de homem livre,

tenho o espírito, pois isso é melhor do que um só homem

sofrer de dois males: ter um coração mau

e também obedecer como escravo àqueles que o rodeiam.]

ME. Vai, ancião, tu que, junto ao escudo, muitas

fadigas cumpriu labutando por mim,

agora também compartilha do meu sucesso

e vai contar aos amigos que deixei para trás

como encontraste as coisas e como está nossa sorte.

Diga-lhes que permaneçam na costa e que aguardem

pelas batalhas que me restam, como espero,

e que, caso possamos, de algum modo, roubar Helena desta terra,

estejam eles preparados para unir-se no nosso mesmo destino

e escapar, se pudermos, destes bárbaros.

SE. Assim será, ó senhor. Mas agora eu vejo

como é barata e cheia de mentiras a arte dos adivinhos.

[Então não há mesmo nada de são na chama dos sacrifícios

ou nas vozes dos pássaros: é ingênuo até mesmo

cogitar que as aves possam ter alguma serventia aos mortais.]

Com efeito, Calcas não disse e nem deu sinal ao exército

de que ele via os amigos morrerem por uma nuvem,

e nem o fez Heleno, mas a cidade foi destruída em vão.

[Dirias: porque o deus não o quis.

Por que então profetizamos? Necessário é aos deuses, com sacrifícios, pedir pelas dádivas, mas deixar de lado a adivinhação.

Aleatoriamente ela foi inventada, um engodo à existência,

e ninguém jamais enriqueceu com sacrifícios, sendo preguiçoso:

o juízo e a prudência são o melhor adivinho.]

CO. Essa mesma opinião sobre os adivinhos

divido com o velho: aquele que tiver os deuses 
como amigos terá a melhor adivinhação em sua casa.

(Provável saída do servo.)

HE. Bom, até aqui tudo vai bem.

Mas o modo como sobreviveste, ó infeliz, desde Troia, não há nenhum lucro em sabê-lo, mas há um certo desejo

[dos amigos de ouvirem as dores daqueles a quem amam.]

ME. Sobre muito me perguntaste em uma só palavra e em uma viagem só.

Para que te contaria sobre as destruições no Egeu

e de Náuplio na Eubeia os faróis

e de Creta e da Líbia as cidades que tenho circundado

e a atalaia de Perseu? Porquanto não te saciaria de histórias,

mas, contando-te dos meus males, mais me afligiria

[como sofri quando os vivenciei; duas vezes nos entristeceríamos].

HE. Falaste até mais do que te perguntei.

Mas uma só coisa diz, deixando de lado o resto: quanto tempo

sobre as costas do mar vagueaste perambulagem marítima?

ME. Nas naus, além dos dez anos em Troia,

passei sete circuitos de anos.

HE. Ai ai! Longo o tempo que me dizes, ó infeliz!

Tendo sobrevivido, de lá para cá vieste para a degola.

ME. Como falas?! O que dirás? Tu me arruínas, mulher!

HE. [Foge o mais rapidamente e parte desta terra.]

Morrerás pelas mãos do homem que possui esta morada.

ME. Que fiz para ser merecedor desses infortúnios? 
HE. Chegaste como obstáculo inesperado às minhas núpcias.

ME. Acaso alguém quis casar com minha esposa?

HE. Ultrajando a mim, e eu teria de suportar.

ME. Alguém que tem poderes privados, ou o que governa esta terra?

HE. O que deste solo é senhor, progênie de Proteu.

ME. É este o enigma que ouvi daquela serva.

HE. A que portas bárbaras paraste?

ME. A estas, de onde, como um pedinte, fui expulso.

HE. Mas não mendigavas pelo sustento, não?! Ó infeliz de mim!

ME. A ação de fato era essa, mas esse nome não tinha.

HE. Tudo sabes então, como parece, sobre as minhas núpcias.

ME. Sei. Mas se escapaste do leito, isso eu não tenho certo.

HE. Sabe que teu tálamo foi preservado intocado.

ME. Que prova há disso? Bem-vindas palavras, se dizes a verdade.

HE. Vês este túmulo, meu sofrido assento?

ME. Vejo uma infeliz cama de palha; que tens a ver com ela?

HE. Aqui suplicamos por uma fuga desse leito. 
ME. Na falta de um altar, ou por costumes bárbaros?

HE. Protegia-nos este túmulo, como os santuários dos deuses.

ME. Não me é possível, então, transportar-te para casa?

HE. A espada te espera antes que meu tálamo.

ME. Assim seria eu o mais desgraçado dos mortais.

HE. Mas agora não te acanhes, foge desta terra.

ME. Deixando-te? Troia arrasei em teu favor!

HE. Pois é melhor do que meu tálamo te matar.

ME. Desviril o que disseste! E também não digno de Ílion.

HE. Não poderias matar o tirano, o que anseias, talvez.

ME. Assim tão invulnerável ao aço tem ele o corpo?

HE. Saberás. Ousar o impossível é próprio do homem não sábio.

ME. Em silêncio, entregarei então minhas mãos para serem atadas?

HE. Uma aporia atinges. Alguma maquinação é necessária.

ME. Pois é melhor morrer agindo do que não agindo.

HE. Única é a esperança pela qual poderíamos nos salvar.

ME. Por suborno, ousadia, ou palavras? 
HE. Se o tirano não ouvir que tu chegaste.

ME. Não perceberá quem sou, eu sei. E quem contará?

HE. Há na casa dele uma aliada aos deuses semelhante.

ME. Alguma voz divina instituída nos recônditos da casa?

HE. Não, é a irmã. De Teônoe chamam-na.

ME. Profético é o nome, mas dize o que ela faz.

HE. De tudo sabe. Dirá ao irmão que estás presente.

ME. Estamos mortos então! Já que não me será possível passar despercebido.

HE. Talvez se pudermos persuadi-la suplicando-lhe...

ME. Fazer o quê? A que esperança me guias?

HE. Que não diga ao irmão que estás presente.

ME. E depois de persuadi-la, da terra tiraríamos o pé?

HE. Com ela ao nosso lado, facilmente. Mas em segredo, não.

ME. É tua tarefa, pois à mulher convém outra mulher.

HE. Saiba que não ficará com os joelhos intocados pelas minhas mãos.

ME. Vai! E se ela não aceitar nossos argumentos?

HE. Morrerás. E eu, infeliz, casarei à força. 
ME. Uma traidora serias; a força é o que alegas.

HE. Mas pela tua cabeça eu juro um sagrado juramento...

ME. Que dizes? Morrerás? E jamais trocarás de leito?

HE. Pela mesma espada; e jazerei junto a ti.

ME. Em vista disso, toma então minha mão direita.

HE. Toco-a; morrendo tu, deixarei a luz do dia.

ME. E eu, privado de ti, acabarei com minha vida.

HE. Então como morreremos de modo a adquirir fama?

ME. Sobre o túmulo, depois de te matar, matar-me-ei.

Primeiro combateremos grande combate

pelo teu leito. Quem quiser que chegue perto.

Pois não desonrarei a glória troiana

e nem, voltando à Hélade, aceitarei grande censura,

eu que, de fato, privei Tétis de Aquiles,

e vi o assassinato de Ájax Telamônio

e o nelida sem filhos; não pensarei eu

ser digno morrer por minha esposa?

Por certo, sem dúvida! Com efeito, se são sábios os deuses,

o homem valente que morre guerreando,

com terra leve o cobrem no túmulo,

mas os covardes em duro recife lançam da terra.

CO. Ó deuses, que um dia seja bem-aventurada a raça

de Tântalo e liberta de males!

HE. Ai, infeliz de mim! É assim que estou quanto à sorte. 
Menelau, arranjemo-nos: sai da casa

a profetisa Teônoe. A casa ressoa,

enquanto são retiradas as barras. Foge! Mas para que fugir?

Estando ausente ou presente, que tu chegaste

aqui ela sabe. Desgraçada, estou arruinada!

A Troia sobrevivendo, de terra bárbara

vieste para cair novamente sobre bárbaras espadas.

(Teônoe sai do palácio, acompanhada por dois ou mais servos.)

TEÔNOE. Guia-me tu, carregando a chama das tochas,

e purifica com enxofre, conforme a lei venerável, os recônditos do éter,

para que recebamos o ar puro do céu.

E tu, por sua vez, se alguém poluiu o caminho,

pisando-o com pé profano, dá-lhe ao fogo purificador

e bate o pinho à frente para que eu passe.

E tendo prestado esta minha cerimônia aos deuses mais uma vez,

a chama do lar à casa recolhei.

Helena, e sobre os meus oráculos? O que pensas?

Está de volta o teu marido Menelau aqui visível,

privado dos navios e de tua imagem.

Ó infeliz, vieste escapando de tamanhas penas,

e nem tens certeza do retorno à casa, ou se permaneces aqui mesmo.

Dissídio há entre os deuses, e uma assembleia a respeito de ti

acontecerá diante de Zeus neste dia.

Hera, de um lado, que a ti hostil antes foi,

agora é bem-disposta e deseja resgatá-lo à pátria

com esta aqui, para que a Hélade saiba

que as bodas de Alexandre, dádiva de Cípris, pseudonúpcias foram.

Cípris, por sua vez, quer arruinar teu retorno,

para que não seja exposta e não apareça que tenha comprado

o concurso de beleza às custas das bodas improdutivas de Helena.

A decisão está em mim: ora, como deseja Cípris, 
contando ao irmão que tu estás aqui, te destruo,

ora, ficando ao lado de Hera, salvo tua vida

ocultando-te do parente, que me ordenara falar

890

quando a esta terra sucedesses de retornar.

[Quem irá sinalizar ao meu irmão

que ele é presente, de modo que me ponha a salvo?]

HE. Ó virgem, suplicante, caio aos teus joelhos

e sento-me em assento não afortunado,

por mim e por este, o qual, apenas tendo encontrado,

estou a ponto de ver morto.

Não me denuncies ao teu irmão que o esposo,

o mais querido, às minhas mãos é chegado.

Salva-o, eu te suplico: pelo teu irmão

não traias nunca a tua piedade,

comprando favores nefandos e injustos.

Com efeito, o deus odeia a violência e ordena a todos

adquirir suas aquisições sem saques.

[Deve ser deixada de lado a riqueza $\dagger$ injusta $\dagger$,

pois comum é o céu a todos os mortais

e também a terra, na qual é forçoso, enquanto enchem suas casas,

não reter as posses alheias nem tomá-las à força.]

Para nós oportunamente, mas infelizmente para mim,

Hermes deu-me ao teu pai para salvar-me a este

marido, que está aqui e deseja reaver-me.

[Como então, estando morto, me recuperaria? E como aquele

o vivo aos mortos devolveria?

Agora observa os interesses dos deuses e do teu pai:]

Acaso a divindade e o morto as coisas alheias

desejariam ou não desejariam devolver?

Penso que sim. Então não é preciso tu respeitar mais

ao irmão insensato do que ao pai valoroso.

Se sendo profetisa e nos deuses acreditando,

a justiça do teu pai arruínas, 
enquanto que ao injusto irmão concedes um favor,

vergonhoso será tu discernir todas as coisas divinas,

as que são e as que serão, mas as justas não.

Quanto a mim, infeliz, em tais males envolvida,

salva-me, concedendo-me isso, acréscimo à justiça.

É que não há ninguém que não odeie Helena entre os mortais:

eu que sou celebrada pela Hélade por ter abandonado meu

marido e ter ido morar nas casas repletas de ouro dos frígios.

Mas se eu for à Hélade e pisar em Esparta mais uma vez,

ouvindo e vendo que pelas artimanhas dos deuses

foram destruídos, e eu traidora então não fui aos amigos,

novamente reconduzida à minha virtude,

prometerei em matrimônio a filha com quem agora ninguém casa

e, deixando aqui a mendicância amarga,

com os tesouros de casa deleitar-me-ei.

Se estivesse morto, na pira, $\dagger$ assassinado $\dagger$,

distante, ausente, com lágrimas, eu lhe mostraria meu afeto;

mas, agora que é presente e a salvo, serei privada dele?

Não, de jeito algum, virgem, mas te suplico isto:

conceda-me esta graça e imita os modos

do pai justo; pois aos filhos é esta a glória

mais bela - a qualquer um nascido de pai valoroso -,

puxar aos pais quanto aos modos.

CO. Lamentáveis palavras aqui presentes

e lamentável tu também. Mas de Menelau anseio

ouvir as palavras que dirá por sua vida.

ME. Eu não me submeteria a cair aos teus joelhos

e nem molhar de lágrimas minhas pálpebras: é que à Troia,

ao tornarmo-nos covardes, envergonharíamos ao máximo.

De fato, dizem que aos homens bem-nascidos convém,

em más circunstâncias, lágrimas dos olhos verter.

Mas bela esta atitude, se bela for, 
eu não a preferiria ante a coragem.

Mas, se te parece correto salvar um homem estrangeiro

que procura recuperar sua mulher,

devolve-a e também me salva; e se não te parece,

agora não seria eu infeliz uma primeira vez, mas já numerosas,

e tu aparecerá como mulher má.

O que digno de nós e justo consideramos

e que tocará ao máximo o teu coração,

direi caído diante deste mausoléu do teu pai.

Ó ancião, que habita esta tumba de pedra,

devolva-a, peço-te de volta a minha consorte,

a que Zeus enviou até aqui para tu guardares para mim.

Sei que nunca a devolverás, porque estás morto,

mas esta, enquanto invoco desde baixo o seu pai,

não julgará digno que o que antes era tão bem-afamado

seja mal falado; já que soberana é agora.

Ó ínfero Hades, também a ti convoco como aliado,

que muitos corpos por causa desta recebeste,

sucumbidos à minha espada, tens tua paga:

ou devolva agora aqueles corpos reanimados novamente,

ou, ao menos, força esta mulher a parecer

ainda mais piedosa do que seu pai †e a devolver minha† esposa.

Se me roubareis minha mulher,

dir-te-ei o que ela omitiu em suas palavras.

Ficas a saber, ó virgem: por juramentos estamos presos

a primeiro ir à luta com teu irmão,

e ou ele ou eu precisa morrer - a questão é simples.

E se ele não quiser confrontar minha força pé contra pé

e apanhar a nós dois pela fome, enquanto suplicamos neste túmulo,

estou decidido a matar a ela e depois a mim,

ao fígado enfiar esta espada de duplo fio

nas costas deste túmulo, para que as correntes de sangue

pinguem da tumba; e jazeremos

dois corpos, um após o outro, sobre esta tumba talhada, 
imorredoura aflição para ti, e censura ao teu pai.

Ah sim! não casará esta com teu irmão,

nem com nenhum outro; eu vou levá-la para mim,

se não para casa, pelo menos, para os mortos.

990

[Que é isso? Com lágrimas, tornando-me ao feminino,

eu seria mais digno de pena do que eficaz.

Mata-nos, se te parece, pois inglórios não matarás;

mas, de preferência, sê persuadida pelas minhas palavras

para que tu sejas justa e eu tome minha esposa.]

CO. Está em teu poder ajuizar, ó jovem, essas palavras:

decide de forma que agrades a todos.

TE. Fui gerada para e também quero viver piedosamente;

amo a mim mesma, e a glória do meu pai

não macularia, e nem ao irmão um favor

1000

concederia do qual eu fosse parecer inglória.

Há um grande templo da justiça

em minha natureza, e isto da parte de Nereu

recebi e tentarei, Menelau, conservá-lo.

Com Hera, já que ela deseja ser-te benévola,

1005

o mesmo voto darei; e que Cípris me

seja favorável, ainda que, em lugar algum, tenha se juntado a mim.

[Pretendo permanecer virgem para sempre.]

Quanto às coisas que junto a esta tumba do meu pai repreendes,

para mim vale o mesmo discurso: eu agiria injustamente

se não a devolvesse, pois ele, se visse a luz do dia,

devolvê-la-ia a ti para mantê-la, e tu a ela.

Com efeito, há punição destas coisas tanto aos ínferos,

quanto também a todos os homens de cima; por um lado, a mente

dos mortos não vive, mas, de outra parte, mantém o juízo

1015

imorredouro ao imorredouro éter advindo.

Para então finalizar sem delonga, silenciarei

sobre o que me rogaram, e da loucura 
do meu irmão jamais serei conselheira.

Sou benévola a ele, ainda que não pareça,

se de ímpio a reverente o faço.

Vós mesmos agora descobri o caminho,

e eu, colocada à distância, silenciarei.

Pelos deuses começai e suplicai

a Cípris que te permita voltar à pátria

e que a intenção de Hera permaneça a mesma,

que quer salvação para ti e teu marido.

E tu, ó meu falecido pai, enquanto eu tiver forças,

jamais tu serás chamado impiedoso ao invés de piedoso.

CO. Ninguém jamais prosperou sendo injusto;

na justiça, está a esperança de salvação.

(Teônoe volta para o palácio.)

HE. Menelau, quanto à virgem, estamos salvos.

Mas agora a um só ponto é preciso que nós conduzamos os raciocínios

para coligirmos um plano comum de salvação.

ME. Escuta-me agora então: há longo tempo estás sob este teto

e estás familiarizada com os servos do rei.

HE. Por que dizes isto? Trazes esperanças

de que, de fato, farás algo proveitoso a nós dois.

ME. Persuadirias algum dos que a quadriga

comandam a nos conceder uma carruagem?

HE. Persuadiria. Mas que fuga fugiremos, inexperientes que somos nas planícies destas terras bárbaras?

ME. Impossível, dizes. Bem, e se, escondendo-me na casa, 
eu matar o soberano com esta espada de duplo fio?

HE. A irmã não suportaria nem silenciaria,

se estivesses a ponto de matar seu irmão.

ME. Além do que não há nau em que nos salvássemos

fugindo, já que a que tínhamos o mar tem agora.

HE. Escuta, se até mesmo uma mulher puder dizer algo de esperto.

Estarias disposto a ser declarado morto por palavra, não estando morto?

1050

ME. Mau é o augúrio, mas se me traria proveito, dize.

Preparado estou para morrer por palavra, não estando morto.

HE. E nós ainda nos lamentaríamos com os cabelos aparados

e com trenos femininos, diante do homem profano.

ME. Mas para nossa salvação que remédio isso tem?

Algo de antiquado há nesta história.

HE. É que estando tu morto no mar, pedirei ao tirano desta terra prestar honras a ti em uma tumba vazia.

ME. E caso ele permita, como então sem nau sobreviveremos, honrando minha pele com um cenotáfio?

HE. Pedirei que conceda uma embarcação, em que deitaremos ornamento à tua tumba nos braços do pélago.

ME. Falaste bem, exceto por uma coisa: se, na terra seca, ele pedir que realize os ritos fúnebres, em nada o pretexto ajuda.

HE. Mas eu direi que não é costume na Hélade sepultar em terra seca os que morreram no mar. 
ME. Isto igualmente endireitas; então eu navegarei contigo

e contigo deitarei ornamento no mesmo barco.

HE. É necessário, sobretudo, que tu também estejas presente e os teus marinheiros, os que escaparam do naufrágio.

ME. E, de fato, se eu tomar uma nau ancorada,

homem contra homem levantar-se-á de espada em punho.

HE. É preciso que tu controles tudo. Ventos condutores nas velas venham apenas, e rota propícia.

ME. Assim será, pois as divindades cessarão minhas penas.

Contudo, de quem dirás ter ouvido que estou morto?

HE. De ti. E dirás que sozinho escapaste ao destino navegando com o filho de Atreu e viste ele morrer.

ME. E, de fato, estes trapos ao redor do meu corpo testemunham contigo a tua história da ruína náutica.

HE. Para bom proveito vieram, ainda que desproveitosas quando destruídas. Aquela infelicidade, de repente, afortunada será.

ME. Acaso é preciso que eu entre junto a ti na casa, ou próximo a este túmulo, sossegados, sentamos?

HE. Fica aqui, pois ainda que ele te faça algo fora de tom, este túmulo te protegeria e tua espada.

E eu vou para casa, cortarei uns cachos do cabelo e os peplos brancos por negros trocarei e nas bochechas enfiarei as unhas sanguinárias à pele.

Grande é a contenda, e vejo dois lados para onde possa cair a balança: 
é que ou é preciso que eu morra, se for pega maquinando,

ou eu retorno à pátria e salvo tua pele.

Ó senhora que no leito de Zeus repousas,

Hera, dois míseros mortais alivia de penas,

pedimos lançando os braços estendidos ao céu,

onde habitas em meio ao brocado das estrelas.

$\mathrm{E}$ tu, que às custas do meu casamento adquiriste a beleza,

jovem filha de Dione, Cípris, não me destruas.

De assaz ultrajes já me ultrajastes,

exibindo o meu nome, mas não meu corpo, entre os bárbaros.

Morrer concede-me, se queres matar-me,

em terra pátria. Por que és insaciável de males,

a amores, enganos, dolos e invencionices

dedicando-te e filtros fatais aos corpos?

Se fosses moderada, em tudo, certamente, a mais doce dentre os deuses serias aos homens - de outro modo não digo.

(Helena entra no palácio.)

CO. A ti em teus retiros sob a coma das árvores,

em salão musical e assento colocado,

convoco,

o mais canoro pássaro musical,

rouxinol lacrimoso,

vem trinando pela bico gorjeante,

em sinergia com meus trenos,

enquanto canto de Helena as penas vãs

e das mulheres de Ílion

o destino lacrimoso

sob as pontas de lanças aqueias,

quando correu pelas ondas cinzentas, em bárbaro remo,

aquele que veio, veio conduzindo aos priamidas lúgubre

leito da Lacedemônia, 
a ti, ó Helena, Páris ofatalmente casado,

a mando de Afrodite.

(Antístrofe A)

E muitos dos aqueus pela lança e por rochosos

arremessos expiraram e o Hades

lúgubre habitam,

das infelizes esposas

cortaram os cabelos,

1125

e sem núpcias jazem as casas.

E a muitos, acendendo com brilho flamejante

a Eubeia cercada de mar, matou um dos aqueus,

homem de remo solitário - nas pedras

cafareias lançando-os,

$1130-1$

e nos promontórios marinhos do Egeu,

1130-1

lampejando o astro doloso.

E a territórios sem porto, lúgubres, de bárbaro vestuário,

foi impelido, longe da pátria, por rajadas de tempestade;

uma dádiva, que não é dádiva, mas dissídio

1135

dos dânaos Menelau nas naus conduzia,

o fantasma sagrado de Hera.

(Estrofe B)

O que é deus, e o que não é deus, e o intermédio?

Qual dos mortais, depois de investigar, vai dizer?

O mais extremo limite encontrou aquele que a vontade dos deuses enxerga,

de cá, para lá, e de volta saltando em incertas,

inesperadas fortunas.

Tu, ó Helena, é filha de Zeus gerada,

pois, nos seios de Leda, um alado

pai te engendrou,

e ainda assim foste proclamada pela Grécia

traidora, infiel, injusta e sem deus; não sei

†o que pode ser claro entre os mortais, a palavra 
(Antístrofe B)

Insanos vós que a glória pela guerra

e pela ponta da forte lança

procurais, estupidamente na morte dissipando as penas.

Se as disputas de sangue devem decidi-lo, jamais o

[dissídio

1157

deixará as cidades dos homens,

†que deixaram sepultura na terra de Príamo, $\dagger$

quando era possível endireitar com argumentos

1160

o teu dissídio, ó Helena.

Mas agora de Hades eles são assunto lá embaixo,

e contra os muros uma chama, †chamejante $\dagger$ como Zeus,

[foi impelida

e mágoas sob mágoas suportas, †em desgraçados

infortúnios lutuosos. $\dagger$

(Entra Teoclímeno e seus servidores pelo eisodos oposto à costa.)

TEOCLÍMENO. Salve, mausoléu paterno! É que junto à saída

te enterrei, Proteu, para minha saudação:

sempre que saindo ou entrando em casa,

este Teoclímeno, teu filho, te chama, pai.

E vós, então, os cães e os laços para as feras

levai, escravos, para a casa do tirano.

Eu mesmo, muitas vezes, de fato, me repreendi,

já que com a morte os maus não castigamos.

E agora ouço que um dos helenos abertamente

${ }^{85}$ Intérpretes tendem a estranhar a repentina confiança na palavra dos deuses, depois da dúvida expressa no começo da estrofe. Allan e Kovacs defendem emendas de Schenkl e Willink que seriam traduzidas assim: "não sei o que seja claro, que palavra verdadeira sobre os deuses eu

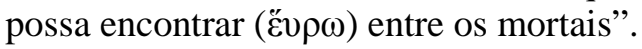


a esta terra chegou, tendo passado despercebido pelos vigias,

por certo ou como espião, ou caçando Helena para roubá-la,

mas morrerá assim que for pego.

$\mathrm{Ah}$ !

Mas parece-me que tudo já concretizado

encontro, pois, tendo deixado vazio o assento do túmulo,

a tindárida filha foi levada desta terra pelo mar.

Oh! soltai as barras, abri as hípicas

manjedouras, servos, e trazei as carruagens,

para que, ao menos, pelo meu esforço, não me escape

levada desta terra a mulher que desejo.

Detende! que vejo os que perseguimos

presentes na casa, e não fugidos.

Tu aí, por que peplos negros penduraste à pele

trocando-os pelos brancos, e da nobre cabeça

o cabelo cortaste infligindo-lhe o aço,

e molhas com lágrimas cintilantes tua bochecha

chorando? Acaso convencida por sonhos

noturnos te lamentas, ou tendo ouvido alguma notícia de casa,

devastas teu coração?

HE. Ó senhor - pois agora por este termo já te nomeio -

estou perdida! Arruinados estão os meus negócios, e eu já não sou nada.

TEOC. Mas em que infortúnios jazes? Que sorte é a tua?

HE. Menelau - ai de mim! como direi? - me é morto.

TEOC. [Em nada me alegro com tuas palavras, ainda que me sejam afortunadas.]

Como soubeste? Não é Teônoe que te conta isto?

HE. Ela o diz, e também alguém que esteve presente quando ele morreu.

TEOC. Alguém que veio e isso reporta com segurança? 
HE. Veio - pois que vá aonde desejo que chegue.

TEOC. Quem é? Onde está? Fala para eu saber mais seguramente.

HE. Este que se sentou agachado no túmulo.

TEOC. Apolo! Com que traje horrível se apresenta!

HE. Ai de mim! Penso que meu marido também tem um desses.

TEOC. Mas de que pátria é este homem e de onde chegou a esta terra?

HE. Da Hélade, é um dos aqueus que navegaram com meu marido.

TEOC. E que tipo de morte diz Menelau ter morrido?

HE. A mais lamentável, nas marolas úmidas do mar.

TEOC. Onde no pélago bárbaro navegava?

HE. Na Líbia, naufragou contra os rochedos inóspitos.

TEOC. E como este, compartilhando o remo, não morreu?

HE. Ignóbeis, às vezes, são mais afortunados do que os nobres.

TEOC. E onde deixou os destroços da nau, antes de vir aqui?

HE. Onde gostaria que perecesse horrivelmente, mas não Menelau!

TEOC. Pereceu aquele. Mas em que barco veio este?

HE. Marinheiros que o encontraram salvaram-lhe, segundo conta. 
TEOC. E onde está o mal mandado a Troia em teu lugar?

HE. A imagem de nuvem, tu dizes? Para o éter partiu.

TEOC. Ó Príamo e terra de Troia, como sucumbes em vão!

HE. Eu, também, tive parte nas desventuras dos priamidas.

TEOC. E deixou teu marido insepulto, ou o cobriu com a terra?

HE. Insepulto! Ai de meus males, miserável que sou.

TEOC. E por causa disso cortaste os cachos da coma loura?

HE. Pois querido †é, seja quem for, estando aqui . $^{86}$

TEOC. É justo, de fato, que esses infortúnios sejam chorados.

$<\mathrm{HE}$.

$$
>
$$

$<$ TEOC.

HE. É fácil, então, passar despercebido por tua irmã.

TEOC. De modo algum. Mas e agora? Habitarás ainda este túmulo?

HE. É que sou fiel ao marido fugindo de ti.

TEOC. Por que me provocas e não deixas o morto em paz?

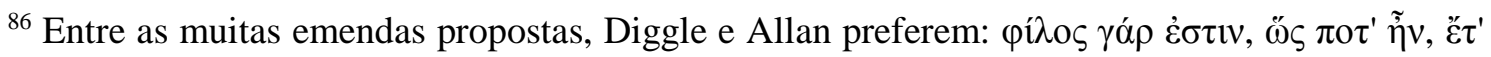

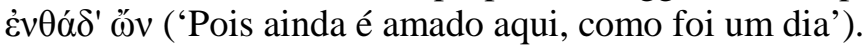


HE. Não mais. Começa já os preparativos das minhas núpcias.

TEOC. Depois de longo tempo isso acontece, mas mesmo assim eu o louvo!

HE. Aí vai o que tens que fazer: esqueçamos o passado.

TEOC. Em que termos? Graça venha em troca de graça.

HE. Façamos uma trégua, e tu te reconcilia comigo.

TEOC. Desisto da minha rixa contigo, que bata asas!

HE. Agora aos teus joelhos, já que és amigo...

TEOC. Que coisa queres alcançar de mim como suplicante?

HE. Ao falecido meu marido quero fazer o funeral.

TEOC. O quê? Não está ausente de tumba? Ou farás o funeral de uma sombra?

HE. Há um costume entre os helenos, quem morrer no mar...

TEOC. Que fazer? Certamente os pelópidas serão sábios a esse respeito.

HE. Fazer o funeral nos tecidos vazios dos peplos.

TEOC. Fazei-lhe as exéquias: erige o túmulo onde quiseres nesta terra.

HE. Não dessa maneira enterramos os marinheiros mortos.

TEOC. Como então? Fico para trás quanto aos costumes da Hélade.

HE. Ao mar levamos o que é necessário ao defunto. 
TEOC. Então o que devo providenciar-te para o falecido?

HE. Este aqui sabe; eu sou ignorante, já que até agora era bem-aventurada.

TEOC. Ó estrangeiro, trouxeste de fato notícias apreciadas.

ME. Não para mim, e nem para o falecido.

TEOC. Como fazeis funerais aos cadáveres mortos no mar?

ME. De acordo com o que cada um tiver disponível.

TEOC. Quanto aos bens, diga o que queres pela graça desta mulher.

ME. Primeiro, sacrifica-se sangue aos ínferos.

TEOC. De que animal? Tu sinaliza-me, e eu o pagarei.

ME. Tu mesmo decide, pois o que deres bastará.

TEOC. Entre os bárbaros, cavalo ou touro é o costume.

ME. E dá apenas o que não for em nada defeituoso.

TEOC. Destes não carecemos em nossos prósperos rebanhos.

ME. E leva-se também um leito coberto, vazio de corpo.

TEOC. Assim será. E que outra coisa costuma-se oferecer?

ME. Armas de cobre, já que também era amigo da lança.

TEOC. Dignas dos pelópidas serão as que daremos. 
ME. Quanto ao resto, tudo o que a terra dá de bons frutos.

TEOC. Mas aí como? Às ondas, de que maneira o lançais?

ME. É preciso que haja uma nau e com remadores.

TEOC. E a que distância da terra é preciso afastar o barco?

ME. De modo a mal avistar-se da costa as espumas dos remos.

TEOC. Por quê? Por que a Grécia respeita tal costume?

ME. Para que as ondas não lancem de volta à terra as impurezas.

TEOC. Rápidos remos fenícios serão providenciados.

ME. Nobre isso seria, e um favor a Menelau.

TEOC. E tu sem esta bastará para tudo cumprir, não?

ME. Esta é tarefa da mãe, da mulher ou dos filhos.

TEOC. Desta é o trabalho, segundo dizes, de fazer o funeral do marido.

ME. Piedosamente, ao menos; o costume é não trapacear os mortos.

TEOC. Que seja, é do meu interesse nutrir uma esposa piedosa.

Depois de ir à casa e escolher o ornamento aos mortos $<$

E a ti não despacharei desta terra de mãos vazias, tendo feito a ela um favor e tendo me trazido boas notícias: em lugar desses trapos, receberás vestuário e alimentos para que à pátria tu chegues, já que agora te vejo tão combalido. 
E tu, infeliz, pelo inútil não

te desgastes $<$

$$
>\text { mas Menelau tem seu lote, }{ }^{87}
$$

e não seria possível, com lamentos, fazer viver o falecido.

ME. Tua tarefa, ó jovem: aquele que está presente

é preciso amar como marido, e deixar ir o que não mais está.

Com efeito, isto é o melhor para ti em face dos acontecimentos.

E se à Hélade eu chegar e tiver salvação,

deterei o opróbrio anterior sobre ti - se fores a mulher

que é preciso que sejas ao teu consorte.

HE. Assim será. E nem censurará jamais o marido

a nós; tu mesmo, estando próximo, saberás disso.

Entra, ó infeliz, toma um banho

e as roupas troca. Sem demora,

cuidarei de ti, pois, mais bem-disposto,

ao meu mais amado Menelau farias

o que for conveniente, de nós obtendo o que te é preciso.

(Teoclímeno, Helena e Menelau entram no palácio.)

CO. Outrora, em pé veloz, (Estrofe A)

correu a Mãe montanhesa dos deuses

pelos bosques arborizados,

e fluviais correntes de água,

e troantes ondas salgadas,

em desejo da afastada

donzela que não pode ser nomeada.

E os bramantes címbalos, penetrante

clamor lançando, bradavam,

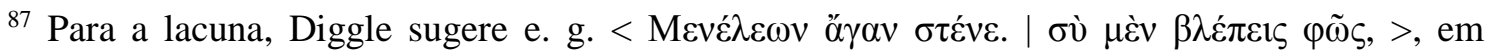
tradução: não < lamentes demais por Menelau. | Tu vês a luz, > mas Menelau tem seu lote. 
quando a uma parelha de feras

a deusa atrelou a carruagem,

(atrás) daquela raptada do círculo

do coro de virgens

†e entre as donzelas $\dagger$

$<v v-v>$ com pés de tempestade, ${ }^{88}$

e então Ártemis com seus arcos, e a

de olhos ferozes com lança totalmente armada.

Mas olhando do celeste

$<-\mathrm{x}-\mathrm{x}-\mathrm{v} \mathrm{v}->89$

outro destino ordenava.

(Antístrofe A)

1320

E quando velozes perambulações

a mãe cessou o afã,

buscando †afãs $\dagger$

o doloso rapto da filha,

e cruzou os cumes nutridos de neve

do monte Ida habitado por ninfas

1325

e, em sofrimento, lança-se

nos rochosos bosques muito nevados.

E aos mortais as planícies da terra desviçosas

$\langle\mathrm{x}-\mathrm{x}-\mathrm{v} \mathrm{v}->$

não fertilizando com safras,

e destrói a raça dos homens;

1330

e aos rebanhos não envia fresca

forragem de folhas espiraladas;

e a vida deixava as cidades,

e nem haviam sacrificios aos deuses,

e as misturas restavam inconsumidas nos altares.

${ }^{88}$ Uma boa solução para essa sequência é proposta por Maas, que rearranja e suplementa os

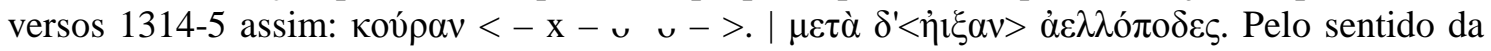
passagem, o verbo que continua faltando deve significar algo como "partiu em busca".

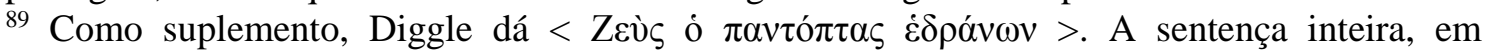
tradução, ficaria: "Mas olhando do celeste assento, Zeus que tudo vê outro destino ordenava." 
Mas quando cessou os banquetes

aos deuses e à progênie dos mortais,

Zeus, querendo aplacar a soturna

raiva da Mãe, profere:

'Ide, reverendas Graças,

parti, a Deo enraivecida

por causa da virgem

$\dagger$ a dor retirai $\dagger$ com brado,

e vós, Musas, com cantos para os coros.'

E a voz ctônica do bronze

e os tambores de pele tesa pegou

então, pela primeira vez, a mais bela

entre os bem-aventurados,

Cípris; e a deusa riu

e tomou em suas mãos

o aulos altissonante,

divertida com seu som.

(Antístrofe B)

$\dagger$ dos quais não é certo nem permitido pela lei divina

consumiste como sacrifício nos leitos $\dagger^{90}$

1355

e tens a cólera da grande

Mãe, ó filha, não tendo honrado

os sacrifícios da deusa.

São, de fato, enormemente poderosos

os variegados trajes de pele de cervo

1360

e o viço da hera laureado

${ }^{90}$ Muito corrompidos, esses versos falam de alguma falta de Helena, não conhecida por outras fontes, que teria motivado a ira de Cibele/Deméter. 


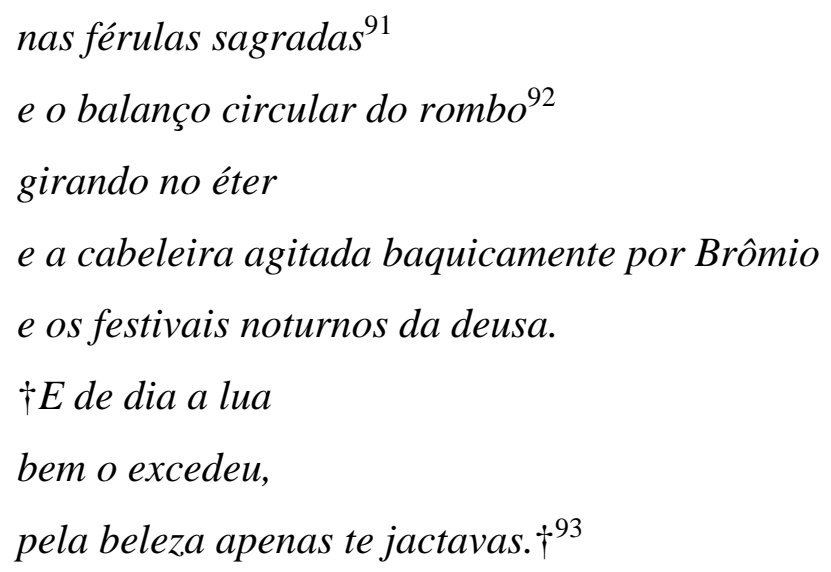

(Helena sai do palácio.)

HE. Quanto às coisas da casa, amigas, somos afortunados.

É que a filha de Proteu, ajudando a esconder

a presença do meu marido, quando questionada,

[não disse ao irmão; mas, morto e na terra,]

afirma que ele não vê a luz do sol - em meu favor.

E o melhor $\uparrow$ de fato fisgou, em sua sorte, $\nmid$ meu marido.

Com efeito, as armas que ele deveria lançar ao mar,

tendo passado seu nobre braço na correia,

ele mesmo carrega, também apanhando a lança na destra,

como se cooperando de fato nas oferendas ao morto.

E adequadamente ataviou o corpo para a luta

para obter, com seu braço, troféus de inúmeros bárbaros,

quando embarcarmos no barco de remos.

E tendo trocado as vestes naufragadas por peplos,

eu mesma lhe paramentei e dei seu corpo ao banho,

aguardadas águas puras de rio.

Mas sai do palácio aquele que imagina

${ }^{91} 1360-1$ descreve o tirso.

${ }^{92}$ Sobre o $\rho$ ó $\mu \beta$ s, West explica que: "It consists of a shaped piece of wood whirled round on the end of a string to produce a demonic roaring noise, and it is widely used in primitive initiation ceremonies. In Greece it was used in some mystery cults, especially those of Dionysus and Cybele, in association with drums and cymbals. It also had magical uses, and it could be a child's toy." (1992, p. 122)

93 A tradução lê $\mu о \rho \varphi \tilde{a}$ como dativo. De resto, é desconhecida essa ofensa de Helena de negligenciar os ritos da deusa por apenas cuidar de sua própria beleza. 
ter meus esponsais em suas mãos,

devo silenciar. E a ti convenço

$<$

gentilmente controlar tua língua; se pudermos

nos salvar, também a ti ajudaremos a salvar um dia.

(Teoclímeno sai do palácio, seguido por Menelau e alguns servos.) $)^{94}$

TEOC. Avançai em ordem, como mandou o estrangeiro,

escravos, levando as oferendas funerárias ao mar.

Mas tu, Helena, se a ti não pareço falar mal,

escuta: fica aqui. Com efeito, as mesmas honras prestarás

ao teu marido, estando presente ou não.

Temo que algum desejo que te caia

vá te persuadir a soltar teu corpo às ondas do mar,

arrebatada pelas graças do marido anterior.

É que ele não estando presente, ainda o lamentas demais.

HE. Ó meu novo esposo, é forçoso

o primeiro marido e a união virginal

honrar. Eu, por amar o marido,

morreria com ele, mas que favor faria ao morto

morrendo com ele? Mas permite a mim

mesma ir e conceder exéquias ao morto.

E que os deuses te concedam o que eu desejo

e a este estrangeiro aqui, já que ele ajuda nisso.

E me terás tal como a mulher que te é preciso ter

em casa, uma vez que a Menelau és gentil

e a mim, pois para algum sucesso caminham as coisas.

Mas aquele que dará a nau em que conduziremos esses ritos

${ }^{94}$ A entrada de Menelau aqui não é anunciada, talvez por ele estar sob os auspícios do rei (HALLERAN, 1985, p.23). Parece pouco plausível que Menelau entre já no verso 1369, uma vez que Helena se refere a ele na terceira pessoa nos versos 1370-84. 
designa, para que eu receba teu favor inteiro.

TEOC. Vai tu e dá a eles uma nau quinquerreme

sidônia e com remadores.

HE. E não comandará a nau este que ordena os ritos fúnebres?

TEOC. Certamente. É preciso que meus marinheiros escutem a ele.

HE. Mais uma vez, ordena, para que claramente eles o aprendam de ti.

TEOC. Mais uma vez, ordeno, e uma terceira até, se te apraz.

HE. Abençoado sejas! E eu por meus propósitos.

TEOC. Mas agora que não dissolvas tua tez com lágrimas demais.

HE. Este dia te mostrará minha gratidão.

TEOC. As coisas dos mortos não são nada, além de trabalho vão.

HE. † São alguma coisa, cá e lá, estes dos quais falo. †

TEOC. Terás a mim como um marido em nada pior a Menelau.

HE. Em nada mereces ser censurado; falta-me sorte apenas.

TEOC. Isto está em tuas mão - se tiveres boa vontade em relação a mim.

HE. Não serei agora instruída sobre como amar os amados.

TEOC. Queres que eu ajude a despachar a expedição?

HE. De jeito nenhum! Não sejas um escravo aos teus escravos, senhor. 
TEOC. Muito bem, então! Aos costumes dos pelópidas não atento.

Com efeito, limpa está minha casa, já que não foi aqui

que Menelau perdeu sua vida. Mas alguém vá

e fale aos meus comandantes para levar presentes de casamento

à minha casa. É preciso que toda

a terra ressoe com hinos alegres,

para que invejáveis sejam as núpcias minhas e de Helena.

E tu, ó estrangeiro, depois de ir aos braços do pélago

e oferecer estas coisas ao que outrora foi marido dela,

apressa-te de volta para a casa conduzindo minha esposa,

para que, banqueteando comigo pelo casamento dela,

possas partir para casa, ou permanecendo prosperar.

(Teoclímeno entra no palácio.)

ME. Ó Zeus, conhecido como pai e deus sábio,

olha por nós e livra-nos dos males,

A nós que arrastamos ao penhasco nossos infortúnios

acode com pressa, se nos tocares com a ponta do dedo,

alcançaremos a sorte que desejamos.

Chega dos sofrimentos que sofremos antes.

Já fostes mesmo chamados, ó deuses, para ouvir de mim muitas coisas inúteis

e dolorosas, mas não devo passar sempre por aflições,

e sim andar em passo firme - concedendo-me uma só graça

fareis o resto da minha vida feliz.

(Helena e Menelau saem pelo eisodos que conduz à costa.)

CO. De Sídon, fenício,

ó rápido remo, remar querido

aos redemoinhos de Nereu,

corego dos belos coros 
de golfinhos, quando

o pélago é sem sopro de brisas,

e a brilhante filha do Mar,

Calmaria, assim fala:

'Desenrolai as velas,

abandonando as brisas marinhas,

e apanhai as lâminas de pinheiro,

ó marinheiros, marinheiros,

que escoltam Helena aos litorais

de bons portos da casa de Perseu.'

(Antístrofe A)

1465

Decerto as garotas leucípides,

junto às vagas do rio, ou defronte ao templo

de Palas, ela encontraria,

depois de longo tempo, juntando-se aos coros,

ou aos cortejos de Jacinto,

1470

na alegria noturna,

- ele que desafiado,

$\dagger$ com o fio da roda do disco, $\dagger$

Febo matou, e para a terra

lacedemônia um dia de sacrifício de bois

o filho de Zeus mandou observar com reverência.

1475

E (encontraria) a novilha que $\dagger$ deixou em casa $\dagger$

$\langle\mathrm{x}-\mathrm{x}-\mathrm{v} \mathrm{v}->$

por cujas núpcias ainda não reluziram as tochas.

(Estrofe B)

Se apenas, através do éter, aladas,

fôssemos para onde na Líbia,

as filas de grous vão

deixando as chuvas de inverno,

confiadas na siringe do mais velho,

seu pastor, que, as áridas 
e frutíferas planícies da terra

sobrevoando, grita.

Ó aves de pescoço longo,

companheiras no curso das nuvens,

ide sob as Plêiades a meio caminho

e Órion noturno,

proclamai a mensagem,

enquanto pousais junto ao Eurotas,

de que Menelau, depois de tomar

a cidade de Dárdano, à casa retorna.

1495

Que vós volteis, pelo trajeto hípico

(Antistrofe B)

acelerando através do éter,

filhos de Tíndaro,

que sob o turbilhão dos astros brilhantes

habitais o céu,

1500

salvadores de Helena,

sobre as brilhantes ondas salgadas,

e escuras ondulações,

e cinzentas vagas do mar,

1505

enviando da parte de Zeus sopros

1504

favoráveis de ventos aos marinheiros,

retirai de tua irmã

a má fama do leito bárbaro

que, por causa da disputa do monte Ida,

obteve em punição,

1510

nunca tendo ido à terra de Ílion,

sobre as torres erguidas por Febo.

(Entra Teoclímeno pela skené. Entra um servo pelo eisodos que conduz à costa.) 
$\dagger$ Senhor, o pior descobrimos na casa. $\dagger^{95}$

Tão estranhas as desgraças que logo ouvirás de mim!

TEOC. Que há? MENS. Arranja a corte de uma outra

mulher, pois Helena foi-se embora desta terra.

TEOC. Elevando-se sobre asas, ou com o pé esmaga-terra?

MENS. Menelau carregou-a por mar desta terra, ele próprio que veio noticiar-se morto.

TEOC. Que coisas terríveis relatas! Mas que navio levou-a desta terra? Inacreditável é o que dizes!

MENS. Aquele mesmo que tu deste ao estrangeiro. Depois de sobrepujar os teus marinheiros, ele partiu - para que o aprendas em poucas palavras.

TEOC. Como? Estou ansioso para saber, pois, dentro das minhas expectativas, não pode ter ido embora superando com um só braço os tantos marinheiros, com os quais foste enviado.

MENS. Quando deixando este palácio real,

a filha de Zeus foi mandada para o mar, muito astutamente, enquanto punha o delicado pé, lastimou o marido próximo e presente, e não morto.

Quando chegamos à área dos teus estaleiros, uma nau de Sídon lançamos em sua primeira viagem com espaço para cinquenta bancos e remos.

Uma tarefa seguia-se a outra.

Com efeito, um trazia o mastro, outro o remo, $\dagger$ na mão, as fileiras de remos $\dagger$, e as brancas velas $\nmid$ reunidas $\dagger^{96}$

${ }^{95}$ Verso com metro defeituoso e sem sentido. Possivelmente foi redigido por alguém que quis preencher a lacuna do texto. 
e os timões com correias foram abaixados.

E durante este serviço, esperando por isso (como depois entendemos), homens gregos, companheiros de Menelau, aproximaram-se da praia vestidos em trajes de náufragos, formosos, mas esquálidos na aparência.

Vendo-os chegarem, o filho de Atreu

dirigiu-se a eles, oferecendo dolosa compaixão:

"Ó infelizes, como, de que nau

da Acaia viestes, tendo naufragado o barco?

Mas ajudai-nos a fazer o funeral do filho falecido de Atreu,

para quem esta filha de Tíndaro erige um cenotáfio em sua ausência."

E eles, derramando lágrimas de modo fingido,

para a nau avançaram, as oferendas marítimas de Menelau

carregando. Havia-nos uma certa suspeita,

e corria um rumor entre nós, de como eram numerosos

os passageiros extras. Contudo, permanecemos calados,

mantendo as tuas resoluções - pois ordenando que o estrangeiro

comandasse a nau, causaste toda esta confusão.

$\mathrm{E}$ as outras coisas, facilmente, para dentro da nau

colocamos, sendo elas leves, mas a pata taurina

não queria pisar direito na rampa,

ao contrário, berrou, virando os olhos em círculo,

arqueando as costas e olhando de soslaio ao longo do chifre

para impedir que o tocassem. E o marido de Helena

conclamou: "Ó saqueadores da cidade de Ílion,

vamos, não elevareis, como no costume grego,

o corpo do touro sobre os jovens ombros

para lançá-lo à proa? †E, ao mesmo tempo, esta espada

à mão não se meterá † na vítima a ser sacrificada ao morto?

Ao seu comando, eles foram, ergueram

o touro, carregaram-no e colocaram-no no convés.

${ }^{96}$ Sigo a interpretação de Amiech ad loc., que defende o texto transmitido e propõe, como paralelo, Tucídides, VI, 85, 3 para sua leitura de $\varepsilon i \varsigma s \tilde{~} v \tilde{\eta} v$. 
E Menelau, alisando o pescoço e a testa do cavalo, convenceu-o a embarcar no navio.

$\mathrm{E}$, finalmente, quando a nau acolheu toda sua carga,

Helena subiu os degraus com seu pé de belo tornozelo

e sentou-se entre os bancos dos remadores,

e aquele, segundo relatos, não mais vivente, Menelau, junto a ela,

E os outros, nos lados direito e esquerdo, parelhos,

homem contra homem, sentaram-se; sob as roupas, espadas

escondidas traziam, e as ondas eram preenchidas

pelo nosso grito, enquanto ouvíamos do contramestre os brados.

Quando estávamos não muito longe da terra, nem perto, assim perguntou o timoneiro:

"Ainda para adiante navegamos, estrangeiro,

ou já está bom? Que o comando da nau pertence a ti."

E ele disse: "É o suficiente para mim." E tomando a espada na destra,

para a proa moveu-se e para o sacrifício do touro

posicionou-se, sem fazer menção a morto nenhum,

mas cortando o pescoço, orou: "Ó tu que habitas o salgado

mar, Posseidon, e reverendas filhas de Nereu,

protegei-me em direção às praias da Náuplia e minha esposa,

incólumes, desta terra." E as torrentes de sangue

jorraram para as ondas, propícias ao estrangeiro.

E alguém disse: "É traiçoeira esta viagem!

Naveguemos de volta, $\uparrow$ pelo caminho certo $\dagger$, ordena tu,

e tu vira o timão." E de onde estava do assassínio do touro,

o filho de Atreu gritou aos aliados:

"Por que demorais, ó flor da terra grega,

para assassinar e matar estes bárbaros e da nau

lançá-los às ondas?” E aos teus marujos

o contramestre grita comando oposto:

"Alguém tome uma trave como arma,

outro quebre o banco, um outro arranque o remo do tolete,

ensanguentai as cabeças desses estrangeiros hostis!"

E todos pularam de pé, alguns segurando pedaços de madeira 
do navio nas mãos, outros com espadas.

E a nau corria em sangue. E da popa vinha

a exortação de Helena: "Onde está a glória de Troia?

Mostrai a estes bárbaros!" Sob ímpeto,

uns caíam, outros se levantavam, e os que jaziam

mortos verias. E Menelau, portando armas,

onde reconhecesse aliados em perigo,

ali levava sua espada na destra,

de modo a lançar-nos da nau ao mar, e assim limpou

os bancos de teus marinheiros. E indo ao timoneiro

ordenou guiar o barco direto para a Hélade.

Eles levantaram o mastro, e ventos favoráveis vieram.

Partiram desta terra. Mas eu, que fugi da morte,

deixei-me cair ao mar junto à âncora,

e, já desgastado, um pescador

me recolheu e pôs-me em terra para ti

trazer esta mensagem. Prudente descrença!

- não há nada mais útil do que ela aos mortais.

(Sai o servo.)

CO. Jamais imaginaria que de ti e de nós Menelau

pudesse passar despercebido, ó senhor, como passou, estando aqui!

TEOCL. Ah, infeliz de mim! que fui pego por artifícios femininos, ${ }^{97}$ escaparam-me minhas núpcias. Se a nau fosse fácil de apanhar em perseguição, empenhando-me logo capturaria os estrangeiros.

Mas agora a irmã que me traiu punirei, a que em casa viu Menelau e não me disse.

Pois bem, jamais enganará outro homem com suas profecias!

SERVO B. Tu aí, para onde levas o pé, ó soberano? Para qual assassinato? ${ }^{98}$

97 1621-41 estão em tetrâmetros trocaicos. O metro é usado nos dramas tardios de Eurípides, principalmente, em diálogos mais excitados e em passagens de agitação. 
TEOC. Para onde a justiça me convoca; mas afasta-te! Para longe do meu caminho!

SE. Não largarei dos teus peplos, pois te precipitas para grandes malefícios.

TEOC. Mas governarás sobre soberanos, mesmo sendo escravo?!

SE. Porque penso fazer o bem.

TEOC. Não a mim! Se não me permitires...

SE. E certamente não o permitirei!

TEOC. ...matar a irmã mais perniciosa...

SE. A mais piedosa, na verdade.

TEOC. A que me traiu...

SE. Uma bela traição, em todo caso - a de fazer o que é justo.

TEOC. Dando minha mulher a outro.

SE. Ao que é mais possuidor.

TEOC. Quem é possuidor do que é meu?

SE. Aquele que a obteve de seu pai.

1635

TEOC. Mas a sorte deu-a a mim.

SE. E a necessidade a levou.

TEOC. Não cabe a ti julgar meus atos.

SE. A não ser que eu tenha melhores coisas a dizer.

TEOC. Então sou comandado, ao invés de governar!

${ }^{98}$ Há dúvidas quanto à identidade do opositor de Teoclímeno, aqui atribuída a um servo, conforme indicação de Diggle. Halleran (1985, p. 49) aponta que, se essa oposição envolve uma entrada, ela certamente é uma entrada surpresa. Para discussão, ver Stanley-Porter (1997), que atribui o papel a um servo de Teônoe. Dale (1967) e Kannicht (1969) apostam no corifeu. 
SE. A fazer o que é certo, e não o injusto.

TEOC. Pareces desejar morrer.

SE. Mata-me! Mas tua irmã, 1640 no que me diz respeito, não matarás, mas a mim - pois pelos senhores morrer é a coisa mais gloriosa aos escravos nobres.

(Aparecem os Dióscuros suspensos na mechané.)

CASTOR. Detém a raiva que não corretamente te carrega,

Teoclímeno, senhor desta terra; nós, os duplos Dióscuros, te chamamos, os que Leda, certa vez, gerou, e também Helena, a que fugiu do teu palácio.

É que por núpcias não apontadas pelo destino te enraiveces, e a donzela gerada da divina nereida não comete injustiça, tua irmã Teônoe, que honrou a vontade dos deuses e as justas ordens de teu pai. [Com efeito, sempre, até o presente momento de agora, carecia que ela morasse em teus palácios, mas, uma vez que as bases de Troia foram extirpadas, e aos deuses ela cedeu seu nome, não mais.

Agora é preciso a ela ficar sob o jugo de suas núpcias e partir para casa para morar com o marido.]

Mas detém a negra espada longe de tua irmã e pensa que sensatamente ela agiu.

Há muito, já anteriormente, a irmã resgataríamos, já que Zeus nos fez deuses, mas somos inferiores ao destino

e também aos deuses, que determinaram que assim fosse.

É o que profiro a ti, mas a minha irmã eu digo: navega com teu marido, terás ventos favoráveis.

E nós, salvadores, teus dois irmãos, cavalgando sobre o mar, te escoltaremos à pátria. 
E quando deres a última volta da corrida e terminares a vida,

serás chamada deusa [e junto com os Dióscuros

partilharás das libações] e presentes dos homens

receberás conosco, pois Zeus assim deseja.

E onde primeiro te trouxe o filho de Maia,

quando te arrebatou de Esparta, em seu curso através dos céus,

roubando teu corpo para que Páris não se casasse contigo,

- digo, a ilha esticada ao longo da Akté ${ }^{99}$ como uma sentinela -

Helena, doravante, será chamada pelos mortais,

já que acolheu a ti, roubada de teus palácios.

1675

E ao errante Menelau, pela vontade dos deuses,

está destinado morar na Ilha dos Bem-Aventurados.

Pois as divindades não odeiam os bem-nascidos,

mas eles $\dagger$ aguentam mais penúrias $\dagger$ do que a multidão dos inumeráveis.

TEOC. Ó filhos de Leda e Zeus, das prévias

contendas a respeito de vossa irmã desistirei.

E que ela vá para casa, se os deuses acham melhor,

e a minha irmã eu não mais matarei.

Sabei †que nascestes do mesmo sangue da irmã $\dagger$

que, ao mesmo tempo, é a melhor e mais sensata.

E regozijai-vos pelo nobilíssimo juízo de Helena,

algo que não há em muitas mulheres.

(Saem os Dióscuros. Teoclímeno e os servos entram no palácio. $O$ coro começa a sair por um dos eisodoi.)

[CO. Muitas são as formas das divindades,

e muitas coisas inesperadamente realizam os deuses,

o que era imaginado não foi cumprido,

e para o que não era imaginado o deus encontrou expediente.

Assim resulta a história.]

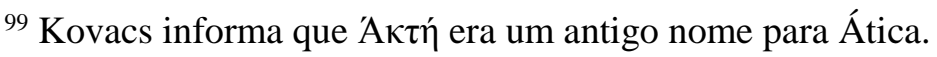




\section{REFERÊNCIAS}

ALLAN, William. Euripides: Helen. Cambridge/New York: Cambridge University Press, 2008.

AMIECH, Christine. Euripide: Hélène. Rennes: Presses Universitaires de Rennes, 2011.

ANDERSON, William S. Calypso and Elysium. In: TAYLOR JR, Charles H. Essays on the Odyssey: Selected Modern Criticism. Bloomington e Londres: Indiana University Press, 1969.

ARNOTT, W. Geoffrey. Euripides' Newfangled Helen. Antichthon, vol. 24, p. 1-18, 1990.

AUSTIN, Norman. Helen of Troy and her shameless phantom. Ithaca: Cornell University Press, 1994.

BARLOW, Shirley A. The Imagery of Euripides: a study in the dramatic use of pictorial language. Bristol: Bristol Classical Press, 1986.

BASSI, Karen. Helen and the Discourse of Denial in Stesichorus' Palinode. Arethusa, Baltimore, v. 26, n. 1, p. 51-71, 1993.

BECK, William. Dogs, Dwellings, and Masters: Ensemble and Symbol in the Odyssey. Hermes, v. 119, p. 158-167, 1991. Disponível em http://www.jstor.org/stable/4476813. Acesso em 13 jun 2011.

BENTLEY, Eric. The Life of the Drama. New York: Atheneum, 1964.

BERGREN, Ann L. T. Helen's 'Good Drug'. In: DOHERTY, Lillian E. Homer's Odyssey (Oxford Readings in Classical Studies). Oxford/New York: 2009. p. 314-335.

BERTINI, Ferruccio. L'eidolon di Elena. In: Mythos. Scripta in honorem Marii Untersteiner. Genova: Istituto di Filologia Classica e Medioevale, 1970, p. 81-96.

BLAISE, Fabienne. Les deux (?) Hélène de Stésichore. In: DUBOIS, Laurent (ed.). Poésie et lyrique antiques: Actes du colloque organisé par Claude Meillier à l'Université Charles-de-Gaulle-Lille III, du 2 au 4 juin 1993. Villeneuve d'Ascq: Presses Universitaires du Septentrion, 1996. p. 29-40.

BLONDELL, Ruby. "Bitch that I Am": Self-Blame and Self-Assertion in the Iliad. Transactions of the American Philological Association, vol. 140, n. 1, p. 1-32, 2010. Disponível

em <http://muse.jhu.edu/login?auth=0\&type=summary\&url=/journals/transactions_of_the_ american_philological_association/v140/140.1.blondell.html>. Acesso em 16 nov 2011.

Refractions of Homer's Helen in Archaic Lyric. American

Journal of Philology, vol. 131, n. 3, p. 349-391, 2010. Disponível em 
<http://muse.jhu.edu/login?auth=0\&type=summary\&url=/journals/american_journal_of _philology/v131/131.3.blondell.html>. Acesso em 23 jan 2011.

BOWMAN, Alan. Recolonising Egypt. In: WISEMAN, T. P. Classics in Progress: Essays on ancient Greece and Rome. Oxford/New York: Oxford University Press, 2002.

BOWRA, C. M. The Two Palinodes of Stesichorus. The Classical Review, v. 13, n. 3, p. 245-52, 1963. Disponível <http://www.jstor.org/stable/4476937>. Acesso em 27 abr 2012.

BOYD, Timothy W. Recognizing Helen. In: SANSONE, David (ed.). Illinois Classical Studies 23, $1998 . \quad$ p. $1-18 . \quad$ Disponível em <https://www.ideals.illinois.edu/bitstream/handle/2142/12302/illinoisclassica231998BO YD.pdf?sequence=2> . Acesso em 27 abr 2012.

BRILLANTE, Carlo. Elena di Troia. In: BETTINI, Maurizio; BRILLANTE, Carlo. Il mito di Elena: immagini e racconti dalla Grecia a oggi. Torino: Einaudi, 2002. p. 37186.

BROOKS, Peter. The Melodramatic Imagination: Balzac, Henry James, Melodrama, and the Mode of Excess. New Haven e Londres: Yale University Press, 1995.

BURIAN, Peter. Euripides: Helen. Oxford: Aris \& Phillips, 2007.

BURNETT, Anne Pippin. Catastrophe survived: Euripides' plays of mixed reversal. Oxford: Clarendon Press, 1971.

CASSIN, Barbara. Encore Hélène: une sophistique de la jouissance. Littoral, vol. 1516, p. 161-183, 1985. Toulouse: Editions Erès.

CERRI, Giovanni. La Palinodia di Stesicoro e la città di Crotone: ragioni di un'innovazione mitica. In: PRETAGOSTINI, Roberto. Tradizione e innovazione nella cultura greca da Omero all'età ellenistica: scritti in onore di Bruno Gentili. Roma: Grupo Editoriale Internazionale, 1993. p. 329-345.

CINGANO, Ettore. Quante testimonianze sulle palinodie di Stesicoro. Quaderni Urbinati di Cultura Classica, Roma, v. 12, p. 21-33, 1982. Disponível <http://www.jstor.org/stable/20538740>. Acesso em 23 abr 2012.

CINGANO, Ettore; GENTILI, Bruno. Sul "Nuovo" verso della prima palinodia di Stesicoro. Zeitschrift für Papyrologie und Epigraphik, Bonn, v. 57, p. 37-40, 1984. Disponível em <http://www.jstor.org/stable/20184101>. Acesso em 23 abr 2012.

CLADER, Linda Lee. Helen: The Evolution from Divine to Heroin in Greek Epic Tradition. Leiden: Brill, 1976.

COELHO, Maria Cecília de Miranda Nogueira. Eurípides, Helena e a Demarcação entre Retórica e Filosofia. 2001. 171 f. Tese (Doutorado em Letras Clássicas) Faculdade de Filosofia, Letras e Ciências Humanas, Universidade de São Paulo, São Paulo, 2001. 
CORRÊA, Paula da Cunha. Um bestiário arcaico: Fábulas e imagens de animais na poesia de Arquíloco. Campinas: Editora da Unicamp, 2010.

CREPALDI, Clara Lacerda. Entre cães e cadelas: a Helena da Ilíada. Nuntius Antiquus, v. 8, p. 51-65, 2012.

DALE, A. M. Euripides: Helen. Oxford: Clarendon Press, 1967.

DEVEREUX, George. Stesichoros' Palinodes: Two Further Testimonia and Some Comments. Rheinisches Museum für Philologie, Bad Orb, v. 116, p. 206-9, 1973. Disponível em <http://www.uni-koeln.de/phil-fak/ifa/rhm/116/Devereux.pdf>. Acesso em 26 abr 2012.

DIGGLE, James. Euripidis fabulae, v. 3. Oxford: Clarendon Press, 1994.

DORIA. Le Due Palinodie di Stesicoro. La Parola del Passato, Napoli, v. 18, p. 81-93, 1963.

DÜBNER, F. Scholia Graeca in Aristophanem. Hildesheim: G. Olms, 1969.

DUBOIS, Page. Sappho and Helen. In: GREENE, Ellen (ed.). Reading Sappho: Contemporary Approaches. Berkeley/Los Angeles/London: University of California Press, 1996. p. 79-88.

EAGLETON, Terry. Depois da Teoria: um olhar sobre os Estudos Culturais e o pósmodernismo. Rio de Janeiro: Civilização Brasileira, 2005.

EDMUNDS, Lowell. Theatrical Space and Historical Place in Sophocles' Oedipus at Colonus. Lanham: Rowman \& Littlefield, 1996.

EISNER, Robert. Echoes of the Odyssey in Euripides' Helen. Maia, vol. 32, p. 31-7, 1980.

EURÍPIDES. Helena (versão do grego, introdução e notas de José Ribeiro Ferreira). Porto Alegre: Movimento, 2009.

FREDRICKSMEYER, Erhard Christian. The Many Faces of Helen in Archaic and Classical Greek Poetry. 1996. PhD dissertation - The University of Texas, Austin, 1996.

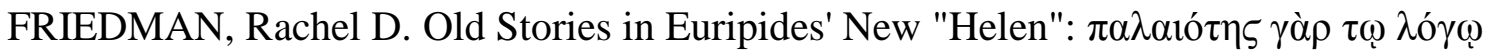

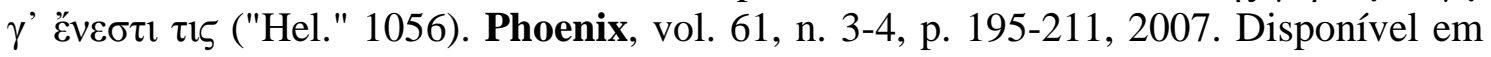
<http://www.jstor.org/stable/20304655>. Acesso em 23 maio 2011.

FOLEY, Helene. Anodos Dramas: Euripides' Alcestis and Helen. In: HEXTER, Ralph; SELDEN, Daniel (ed.). Innovations of Antiquity. New York: Routledge, 1992. p. 13360.

FORD, Andrew L. "A Song to Match my Song": Lyric Doubling in Euripides' Helen. In: MITSIS, P; TSAGALIS, C. (Ed.). Allusion, authority, and truth: critical 
perspectives on Greek poetic and rhetorical praxis (Festschrift for Pietro Pucci). Berlim: W. de Gruyter, 2010.

GAGNEBIN, Jeanne-Marie. Morte da Memória, Memória da Morte: da Escrita em Platão. In: . Sete Aulas sobre Linguagem, Memória e História. Rio de Janeiro: Imago, 1997. p. 49-67.

GHALI-KAHIL, Lilly B. Les Enlèvements et le Retour d'Hélène: dans les textes et les documents figurés. Paris: E. De Boccard, 1955.

GOLANN, Cecil Paige. The Third Stasimon of Euripides' Helena. Transactions and Proceedings of the American Philological Association, v. 76, p. 31-46, 1945. Disponível em <http://www.jstor.org/stable/283323>. Acesso em 27 jan 2010.

GOLDHILL, Simon. Reading Differences: The Odyssey and Juxtaposition. In: JONG, Irene J. F. (ed.). Homer: critical assessments, v. 4 (Homer's Art). Londres / Nova Iorque: Routledge, 1999. p. 396-431.

GRAVER, Margaret. Dog-Helen and Homeric Insult. Classical Antiquity, Berkeley, vol. 14, n. 1, p. 41-61, 1995. Disponível em http://www.jstor.org/stable/25000142. Acesso em 24 mar 2011.

GRAZIOSI, Barbara; HAUBOLD, Johannes (Ed.). Homer: Iliad Book VI. Cambridge: Cambridge University Press, 2010.

GRÉGOIRE, Henri. Hélène. In: GRÉGOIRE, Henri; MÉRIDIER, Louis. Euripide. Tome V (Hélène; Les Phéniciennes). Paris: Belles Lettres, 1950.

GRIFFITH, J. G. Some thoughts on the 'Helena' of Euripides. The Journal of Hellenic Studies, v. 73, p. 36-41, 1953. Disponível em <http://www.jstor.org/stable/628233>. Acesso em 27 jan 2010.

GROTEN, F.J. Homer's Helen. Greece \& Rome, v. 15, n. 1, p. 33-39, 1968. Disponível em <http://www.jstor.org/stable/642254>. Acesso em 27 nov 2009.

GRUBE, G. M. A. The Drama of Euripides. London: Methuen, 1941.

HAMILTON, Richard. Prologue Prophecy and Plot in Four Plays of Euripides. The American Journal of Philology, v. 99, n. 3, p. 277-302, 1978. Disponível em <http://www.jstor.org/stable/293738>. Acesso em 28 jan 2010.

Euripidean Priests. Harvard Studies in Classical Philology, v. 89, p. 53-73, 1985. Disponível em < http://www.jstor.org/stable/311268>. Acesso em 13 jun 2011.

HARTIGAN, Karelisa V. Myth and the Helen. Eranos, v. 79, 1981. p. 23-31.

HOLMBERG, Ingrid E. Euripides' Helen: Most Noble and Most Chaste. The American Journal of Philology, v. 116, n. 1, p. 19-42, 1995. Disponível em <http://www.jstor.org/stable/295501>. Acesso em 31 jul 2009. 
HOMERO. Odisséia. Tradução: Carlos Alberto Nunes. Rio de Janeiro: Editora Três, 1974.

Ilíada. Tradução: Frederico Lourenço. Lisboa: Cotovia, 2010.

ISSACHAROFF, Michael. Space and Reference in Drama. Poetics Today, v. 2, n. 3, p. 211-224, 1981. Disponível em <http://www.jstor.org/stable/1772472〉. Acesso em 1 maio 2013.

JENKINS, Ian. Is there Life after Marriage? A Study of the Abduction Motif in Vase Paintings of the Athenian Wedding Ceremony, Bulletin of the Institute of Classical Studies, vol. 30, p. 137-45, 1983. Disponível em <http://onlinelibrary.wiley.com/doi/10.1111/j.2041-5370.1983.tb00443.x/abstract>. Acesso em 23 jan 2012.

JUDET DE LA COMBE, Pierre. Entre philosophie et philologie. Définitios et refus du tragique. In: MORENILLA, Carmen; ZIMMERMANN, Bernhard (eds). Das Tragische. Sttugart/Weimar: Verlag J. B. Metzler, 2000.

JONG, Irene J. F. Narratological commentary on the Odyssey. New York: Cambridge University Press, 2001.

JUFFRAS, Diane M. Helen and Other Victims in Euripides' 'Helen'. Hermes, v. 121, n. 1, p. 45-57, 1993. Disponível <http://www.jstor.org/stable/4476937〉. Acesso em 31 jul 2009.

KANNICHT, Richard. Helena. Heidelberg: Carl Winter, 1969. 2 v.

KAKRIDIS, Johannes. Problems of the Homeric Helen. In: Homer Revisited. Lund: CWK Glerup, 1971. p. 25-53.

KARSAÏ, György. La destruction d'une généalogie (L'Hélène d'Euripide). In: AUGER, Danièle; SAÏD, Suzanne. Généalogies mythiques: actes du VIIIe Colloque du Centre de recherches mythologiques de l'Université de Paris-X (Chantilly, 14-16 septembre 1995). Nanterre: Centre de recherches mythologiques de l'Université de Nanterre, 1998. p. 307-324.

KELLY, Adrian. Stesikhoros and Helen. Museum Helveticum, Zürich, v. 64, n. 1, p. 121, 2007. Disponível em <http://dx.doi.org/10.5169/seals-49497>. Acesso em 5 maio 2012.

KENNEDY, George A. Helen's Web Unraveled. Arethusa, vol. 19, n. 1, p. 5-14, 1989.

KIRK, G. S. The Iliad: a commentary, v. 1 (books 1-4). Cambridge: Cambridge University Press, 1985.

KITCHELL, Kenneth F. Man's best friend? The changing role of the dog in Greek society. In: FRIZELL, Barbro Santillo. Pecus. Man and animal in antiquity. Proceedings of the conference at the Swedish Institute in Rome, September 9-12, 2002. 
p. 177-182. Disponível em http://www.isvroma.it/public/pecus/kitchell.pdf. Acesso em 3 fev 2009.

KITTO, H. D. F. Greek Tragedy: A Literary Study. London: Methuen, 1950.

KOVACS, David. Euripides: Helen, Phoenician Women, Orestes (v. 5). Cambridge: Harvard University Press, 2002.

Euripidea Tertia. Leiden: Brill, 2003.

LEE, Ken. Helen's Famous Husband and Euripides Helen 1399. Classical Philology, v. 81, n. 4, p. 309-313, 1986. Disponível em <http://www.jstor.org/stable/269980>. Acesso em 13 jun 2011.

LEFKOWITZ, Mary. Women in greek myth. Bristol: Bristol Classical Press, 1986.

Visits to Egypt in the Biographical Tradition. In: ERLER, Michael; SCHORN, Stefan. Griechische Biographie in hellenistischer Zeit: Akten des internationalen Kongresses vom 26.-29. Juli 2006 in Würzburg. Berlin/New York: Walter de Gruyter, 2007. p. 101-113.

LEVET, J. P. Le vrai et le faux dans la pensée grecque archaïque: étude de vocabulaire. Tome I. Paris: Les Belles Lettres, 1976.

LESKY, Albin. A Tragédia Grega. São Paulo: Perspectiva, 1971.

LLOYD, Michael. Paris/Alexandros in Homer and Euripides. Mnemosyne, vol. 42, p. 76-79, 1989. Disponível em <http://www.jstor.org/stable/4431780>. Acesso em 13 set 2011 .

. The Helen Scene in Euripides' Troades. The Classical Quarterly, v. 34, n. 2, p. 303-13, 1984. Disponível em <http://www.jstor.org/pss/638290>. Acesso em 27 jan 2010.

LORAUX, Nicole. Le fantôme da la sexualité. In: Les Expériences de Tirésias: le féminin et l'homme grec. Paris: Gallimard, 1989. p. 233-252.

LOURENÇO, Frederico. An Interpolated Song in Euripides? Helen 229-52. The Journal of Hellenic Studies, vol. 120, p. 132-9, 2000. Disponível em <http://www.jstor.org/stable/632485>. Acesso em 5 dez 2011.

MACEDO, José Marcos Mariani de. A Palavra Ofertada: uma análise retórica e formal dos hinos gregos e da tradição hínica grega e indiana. 2007. 301 f. Tese (Doutorado em Letras Clássicas) - Faculdade de Filosofia, Letras e Ciências Humanas, Universidade de São Paulo, São Paulo, 2007.

MANIET, Albert. Pseudo-interpolations et Scène de Ménage dans l'Odyssée. L'Antiquité Classique, vol. 16, 1947, p. 37-46. 
MAYER, Kenneth. Helen and the $\Lambda \mathrm{IO} \Sigma \mathrm{BOY} \Lambda \mathrm{H}$. The American Journal of Philology, vol. 117, n. 1, p. 1-15, 1996. Disponível em <http://www.jstor.org/stable/1562150>. Acesso em 13 set 2011.

MASTRONARDE, Donald J. Euripidean Tragedy and Genre: The Terminology and its Problems. Illinois Classical Studies, vol. 24-25, p. 23-39, 1999-2000. Disponível em <http://hdl.handle.net/2142/13154>. Acesso em 13 jun 2011.

2010.

The Art of Euripides. New York: Cambridge Unviersity Press,

MELTZER, Gary S. "Where Is the Glory of Troy?" Kleos in Euripides' Helen. Classical Antiquity, Berkeley, v. 13, n. 2, p. 234-255, 1994. Disponível <http://www.jstor.org/stable/25011015>. Acesso em 31 jul 2009.

MORETTI, The Theater of the Sanctuary of Dionysus Eleuthereus in Late FifthCentury Athens. Illinois Classical Studies 24-25, 377-398, 1999-2000.

NIEDDU, Gian Franco. A Poet at Work: The Parody of Helen in the Thesmophoriazusae. Greek, Roman, and Byzantine Studies, v. 44. p. 331-360. 2004. Disponível em <http://www.duke.edu/web/classics/grbs/FTexts/44/Nieddu.pdf>. Acesso em 21 maio 2005.

OLSON, S. Douglas. The Stories of Helen and Menelaus (Odyssey 4.240-89) and the Return of Odysseus. The American Journal of Philology, v. 110, p. 387-394, 1989. Disponível em <http://www.jstor.org/stable/295214>. Acesso em 27 nov 2007.

PADEL, Ruth. 'Imagery of the Elsewhere' Two Choral Odes of Euripides. The Classical Quarterly, v. 24, n. 2, p. 227-241, 1974. Disponível em <http://www.jstor.org/stable/638484>. Acesso em 28 jan 2010.

PAGE, Denys L (ed.). Poetae Melici Graeci: Alcmanis Stesichori Ibyci Anacreontis Simonidis Corinnae Poetarum Minorum Reliquias Carmina Popularia et Convivialia Quaequae Adespota Feruntur. Oxford: Clarendon Press, 1962.

Sappho and Alcaeus: an introduction to the study of ancient lesbian poetry. Oxford: Clarendon Press, 1987.

PAPI, D. G. Victors and sufferers in Euripides' Helen, The American Journal of Philology, v. 108, p. 27-40, 1987. Disponível em <http://www.jstor.org/pss/294912>. Acesso em 27 jan 2010.

PIPPIN, Anne Newton. Euripides' Helen: A Comedy of Ideas. Classical Philology, v. 55, n. 3, p. 151-163, 1960. Disponível em <http://www.jstor.org/stable/266350>. Acesso em 19 jul 2009.

PODLECKI, Anthony J. The Basic Seriousness of Euripides' Helen. Transactions and Proceedings of the American Philological Association, v. 101, p. 401-418, 1970. Disponível em <http://www.jstor.org/stable/2936061>. Acesso em 21 nov 2009. 
POST, L. A. Menander and the Helen of Euripides. Harvard Studies in Classical Philology, v. 68, p. 99-118. 1964. Disponível em <http://www.jstor.org/stable/310800>. Acesso em 13 jun 2011.

PUCCI, Pietro. The Helen and Euripides' "Comic" Art. Colby Quarterly, v. 33, p. 4275, 1997.

PULQUÉRIO, Manuel de Oliveira. O Problema das Duas Palinódias de Estesícoro. Humanitas, Coimbra. v. 25-26, p. 265-273, 1973-1974. Disponível em $<$ http://www.uc.pt/fluc/eclassicos/publicacoes/ficheiros/humanitas25-

26/11_Pulquerio.pdf>. Acesso em 15 nov 2008.

RACE, William H. Sappho, fr. 16 L-P. and Alkaios, fr. 42 L-P.: Romantic and Classical Strains in Lesbian Lyric. Classical Journal, v. 85, n. 1, p. 16-33, 1989. Disponível em <http://www.jstor.org/stable/3297484>. Acesso em 2 maio 2012.

RAGUSA, Giuliana. Fragmentos de uma Deusa: A Representação de Afrodite na Lírica de Safo. Campinas: Editora da Unicamp, 2005.

REECE, Steve. The stranger's welcome: oral theory and the aesthetics of the Homeric. Ann Arbor: University of Michigan, 1993.

REHM, Rush. The Play of Space: Spatial Transformation in Greek Tragedy. Princeton: Princeton University Press, 2002.

RICHARDSON, Nicholas. The Iliad: a commentary, v. 6 (books 21-24). Cambridge: Cambridge University Press, 1993.

RISSMAN, Leah. Love as War: Homeric Allusion in the Poetry of Sappho. Königstein: Verlag Antoin Hain, 1983.

ROBERTS, Deborah H. Parting Words: Final Lines in Sophocles and Euripides. The Classical Quarterly, v. 37, n. 1, 1987, p. 51-64. Disponível em <http://www.jstor.org/stable/639343>. Acesso em 31 jan 2009.

ROBINSON, D. B. Helen and Persephone, Sparta and Demeter. In: BOWERSOCK, Glen W.; BUKERT, Walter; PUTNAM, Michael C. J. Arktouros: Hellenic Studies presented to Bernard M. W. Knox on the occasion of his $65^{\text {th }}$ birthday. Berlin/New York: De Gruyter, 1979. p. 162-172.

ROISMAN, Hanna M. Helen in the Iliad; Causa Belli and Victim of War: From Silent Weaver to Public Speaker. American Journal of Philology, v. 127, p. 1-36, 2006. Disponível em <http://www.jstor.org/stable/3804922>. Acesso em 26 jan 2010.

ROSE, Gilbert P. Odysseus' Barking Heart. Transactions of the American Philological Association, v. 109, p. 215-230, 1979. Disponível em <http://www.jstor.org/stable/284059>. Acesso em 17 jun 2011. 
SCHMIEL, Robert. Telemachus in Sparta. Transactions of the American Philological Association, v. 103, p. 463-472, 1972. Disponível em <ttp://www.jstor.org/stable/2935988>. Acesso em 13 out 2011.

SCODEL, Ruth. Odysseus' Dog and the Productive Household. Hermes, v. 133, n. 4, p. 401-408, 2005. Disponível em http://www.jstor.org/stable/4477672. Acesso em 26 abr 2011.

SCOTT, John A. Dogs in Homer. The Classical Weekly, v. 41, v. 15, p. 226-228, 1948. Disponível em http://www.jstor.org/stable/4342451. Acesso em 13 jun 2011.

SEGAL, Charles. The Two Worlds of Euripides' Helen. Transactions and Proceedings of the American Philological Association, v. 102, p. 553-614, 1971. Disponível em <http://www.jstor.org/stable/2935956>. Acesso em 04 jul 2009.

SIDER, David. The Blinding of Stesichorus. Hermes, Stuttgart, v. 117, n. 4 p. 423-431, 1989. Disponível em <http://www.jstor.org/stable/4476717>. Acesso em 23 abr 2012.

SOUSA E SILVA, Maria de Fátima. Ecos da Odisseia na Helena de Eurípides. Mathesis, vol. 13, p. 227-242, 2004. Disponível em <http://www4.crb.ucp.pt/biblioteca/Mathesis/Mat13/Mathesis13_227.pdf>. Acesso em 30 dez 2009.

Clássicos, vol. 46, p. 11-15, 2006. Disponível em <http://www.uc.pt/fluc/eclassicos/publicacoes/ficheiros/BEC46/01_-_Grego_-

_MFS.pdf $>$. Acesso em 24 set 2009.

SKUTSCH, Otto. Helen, Her Name and Nature. The Journal of Hellenic Studies, vol. 107, p. 188-193, 1987. Disponível em <http://www.jstor.org/stable/630087>. Acesso em 28 set 2011.

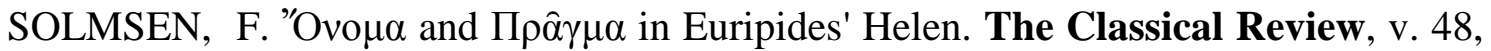
n. 4, p. 119-121, 1934. Disponível em <http://www.jstor.org/stable/697551>. Acesso em 31 jul 2009.

STANLEY-PORTER, D. P. Who Opposes Theoclymenus? Classical Philology, vol. 72, p. 45-8, 1977. Disponível em <http://www.jstor.org/stable/267651>. Acesso em 21 nov 2011.

SUTER, Ann. Aphrodite/Paris/Helen: A Vedic Myth in the Iliad. Transactions of the American Philological Association, vol. 117, p. 51-58, 1987. Disponível em <http://www.jstor.org/stable/283958>. Acesso em 28 set 2011.

SWIFT, L. A. How to Make a Goddess Angry: Making Sense of the Demeter Ode in Euripides' Helen. Classical Philology, vol. 104, n. 4, p. 418-438, 2009. Disponível em < http://www.jstor.org/stable/10.1086/650978>. Acesso em 13 jun 2011. 
TAPLIN, Oliver. Fifth-Century Tragedy and Comedy: A Synkrisis. The Journal of Hellenic Studies, v. 106, p. 163-174, 1986. Disponível em <http://www.jstor.org/stable/629650>. Acesso em 5 nov 2008.

The Stagecraft of Aeschylus: The Dramatic Use of Exits and Entrances in Greek Tragedy. Oxford: Clarendon Press, 1989.

Greek Tragedy in Action. 2 ed. London: Methuen, 2003.

THOMASSEAU, Jean-Marie. O Melodrama. Tradução e notas Claudia Braga e Jacqueline Penjon. São Paulo: Perspectiva, 2005.

TORRANO, José Antonio Alves. O jogo de aparências e de opiniões na tragédia Helena de Eurípides. Epos: revista de filología, vol. 26, p. 13-32, 2010. Disponível em $<$ http://e-spacio.uned.es/fez/eserv.php?pid=bibliuned:Epos-2010-26-

5010\&dsID=Documento.pdf $>$. Acesso em 25 ago 2011.

VOELKE, Pierre. Beauté d'Hélène et rituel féminin dans l'Hélène d'Euripide. Kernos, vol. 9, p. 281-296, 1996. Disponível em <http://kernos.revues.org/pdf/1177>. Acesso em 16 set 2011.

TORRANCE, Isabelle. On Your Head Be It Sworn: Oath and Virtue in Euripides' Helen. The Classical Quaterly, v. 59, n. 1, 2009. Disponível em <http://journals.cambridge.org/production/action/cjoGetFulltext?fulltextid=5476976>.

Acesso em 02 nov 2009.

VERRALL, Arthur W. Euripides' Apology (Helen). In: VERRALL, Arthur W. Essays on Four Plays of Euripides. Cambridge: Cambridge University Press, 1905.

WERNER, Christian. Lágrimas em verso: o canto crítico em Aristófanes e Eurípides. (No prelo).

WEST, M. L. Immortal Helen. London: Bedford College, 1975.

Review of Linda Lee Clader. The Classical Review, v. 28, n. 1, p. 145, 1978. Disponível em <http://www.jstor.org/stable/3062602>. Acesso em 13 jun 2011.

Ancient Greek Music. New York: Oxford University Press, 1992.

WILLIAMSON, Margaret. Sappho and the Other Woman. In: GREENE, Ellen (ed.). Reading Sappho: Contemporary Approaches. Berkeley/Los Angeles/London: University of California Press, 1996. p. 248-64.

WILLINK, C.W. The reunion duo in Euripides' Helen. The Classical Quaterly, v. 39, p. 45-69, 1989. Disponível em <http://www.jstor.org/pss/639241>. Acesso em 27 jan 2010 .

The Parodos of Euripides' Helen (164-90). The Classical Quarterly,

New Series, v. 40, n. 1, p. 77-99, 1990. Disponível em <http://www.jstor.org/stable/639312>. Acesso em 28 out 2011. 
WOLFF, Christian. On Euripides' Helen. Harvard Studies in Classical Philology, v. 77, p. 61-84, 1973. Disponível em <http://www.jstor.org/stable/311060>. Acesso em 04 jul 2009.

WOODBURY, Leonard. Helen and the Palinode. Phoenix, Toronto, v. 21, n. 3, p. 15776, 1967. Disponível em <http://www.jstor.org/stable/1086742>. Acesso em 31 jul 2009.

WORMAN, Nancy. The Body as Argument: Helen in Four Greek Texts. Classical Antiquity, Berkeley, v. 16, n. 1, p. 151-203, 1997. Disponível em <http://www.jstor.org/stable/25011057>. Acesso em 31 jul 2009.

WRIGHT, Matthew. Euripides' Escape Tragedies: A Study of Helen, Andromeda, and Iphigenia among the Taurians. Oxford: Oxford University Press, 2005.

Orestes, a Euripidean Sequel. The Classical Quatterly, vol. 56, p. 3347, 2006. Disponível em <http://www.jstor.org/stable/4493386>. Acesso em 13 set 2011.

YAMAGATA, Naoko. Homeric morality. Leiden: Brill, 1993.

ZUNTZ, Günther. On Euripides' Helena: Theology and Irony. In: KAMERBEEK, J. C. et alii. Euripide: sept exposés et discussions. Entretiens sur l'Antiquité Classique. Tome VI. Genève: Fondation Hardt, 1958. 